\title{
Asymmetric Diffusion: World Bank 'Best Practice' and the Spread of Arbitration in National Investment Laws
}

\author{
Tarald Laudal Bergei and Taylor St Johnii \\ Forthcoming in Review of International Political Economy.
}

\begin{abstract}
Globally, 74 countries have domestic investment laws that mention investor-state arbitration and 42 of these laws provide consent to it. That is, they give foreign investors the right to bypass national courts and bring claims directly to arbitration. What explains this variation, and why do any governments include investor-state arbitration in domestic legislation? We argue that governments incorporate arbitration into their domestic laws because doing so was labelled 'international best practice' by specialist units at the World Bank. We introduce the concept of asymmetric diffusion, which occurs when a policy is framed as international best practice but only recommended to a subset of states. No developed state consents to arbitration in their domestic law, nor does the World Bank recommend that they do so. Yet we show that governments who receive technical assistance from the World Bank's Foreign Investment Advisory Service are more likely to include arbitration in their laws. We first use event history analysis and find that receiving World Bank technical assistance is an exceptionally strong predictor of domestic investment laws with arbitration. Then we illustrate our argument with a case study of the Kyrgyz Republic's 2003 law.
\end{abstract}

i Department of Political Science \& PluriCourts, University of Oslo, Norway (t.l.berge@stv.uio.no) ii School of International Relations, University of St Andrews, United Kingdom (taylor.stjohn@standrews.ac.uk). We would like to thank Jonathan Bonnitcha, Julia Calvert, Ole Kristian Fauchald, Geoffrey Gertz, Yoram Haftel, Carl Henrik Knutsen, Mikael Rask Madsen, Daniel Naurin, Øyvind Stiansen, Henning Tamm, Kyla Tienhaara, and Zoe Williams for comments, and Stein Arne Brekke, Hyewon Han, Karin Maria Svånå, and Maxim Usynin for excellent research assistance. Previous versions of the paper were presented at the LEGINVEST conference (2019), the International Studies Association Annual Conference (2019), at PluriCourts and at the Department of Political Science at the University of Oslo. Support for this project comes from the Research Council of Norway through its Centres of Excellence funding scheme, project number 223274 and through the FRIPRO scheme, project number 276009. This draft was initially prepared for presentation on 5 September 2019 at the Columbia Center on Sustainable Investment and revised 14 January 2020. 


\section{Introduction}

In 2009, a tribunal of arbitrators in the World Bank's Paris office debated a few words of Venezuelan law at length, before deciding it did not give them jurisdiction to decide a claim brought by Mobil Corporation against Venezuela.1 If the Venezuelan law had been clearer, the Mobil award and several others against Venezuela might have been larger, likely billions of dollars larger.2 For governments deciding whether or not to include investor-state arbitration in their domestic investment laws, the stakes are high.

To date, 61 known investor-state arbitration cases have relied on domestic laws (Hepburn, 2018, p. 659) and there is potential for many more. At least 74 countries have domestic investment laws that mention investor-state arbitration (or have mentioned it), and 42 of these laws provide consent to this form of arbitration (or provided consent, before being rewritten). What explains this variation in domestic investment laws?

Governments' decisions to mention arbitration in their domestic laws are puzzling for several reasons. First, arbitration clauses can be extremely costly. If cases are brought and the investor wins, arbitrators can compel the government to pay large monetary awards. Legal costs for states are often substantial, averaging US\$5 million per case, regardless of the outcome (Pelc, 2017, p. 566). Second, the benefits are uncertain. While governments may hope for additional investment, available evidence shows that giving investors access to investment arbitration does

1 Mobil and others v. Venezuela, ICSID Case No. ARB/07/27, Decision on Jurisdiction (2010, pp. 19-33).

${ }_{2}$ ConocoPhillips and ExxonMobil routed their investment in Venezuela through Dutch subsidiaries and also brought claims under the Netherlands-Venezuela bilateral investment treaty. The arbitral tribunal found they had jurisdiction for all aspects of the disputes after the investments were incorporated through the Dutch subsidiary (in the case of ExxonMobil, after 21 February 2006) but not before that date. If the tribunal had found that the domestic law provided jurisdiction, the firms would likely have been awarded compensation for events before that date as well. 
not necessarily lead to additional investment (Bonnitcha, Poulsen \& Waibel, 2017, pp. 158-166).

Third, no developed states have ever consented to arbitration in their domestic laws, so governments are not emulating successful examples (UNCTAD, 2016). Fourth, there are no domestic constituencies likely to lobby for investment arbitration, since it disadvantages domestic investors by giving foreigners a right that citizens do not have (Bonnitcha et al., 2017, pp. 181-192; Betz \& Pond, 2019). So why do any governments mention investor-state arbitration in their domestic laws?

We argue that governments incorporate arbitration into their domestic laws because doing so was labelled 'international best practice' by specialist units at the World Bank. To make our argument, we draw on literature about analytic institutions within international organizations (IOs) - the specialist units that design metrics to assess country performance, define international best practice, and write templates for policy reforms (Broome \& Seabrooke, 2012; Broome, Homolar, \& Kranke, 2018; Cooley \& Snyder, 2015; Davis, Fisher, Kingsbury, \& Merry, 2012; Kelley \& Simmons, 2015, 2019; Merry, Davis, \& Kingsbury, 2015; Sharman, 2012; Vetterlein, 2012).

This literature often highlights that IO legitimacy and influence rest on claims of universality; the very idea of international best practices asserts that a certain set of practices is best anywhere. Yet what we observe and explain is asymmetric diffusion - a policy is framed as universal best practice but only recommended to a subset of states. This is novel; even previous scholarship that considers how political contestation shapes IO policy recommendations (Chorev, 2013; Kentikelenis and Seabrooke, 2017) does not consider asymmetric diffusion. Analytic institutions within the World Bank have framed references to investor-state arbitration in domestic law as a policy solution since the 1960s. These analytic institutions have 
collected domestic investment laws, defined best practice, and written templates for domestic investment laws in the decades since then. Therefore we hypothesize that after a government receives advice on reforming its domestic investment law from a particular analytic institution within the World Bank Group, the Foreign Investment Advisory Service (FIAS), that government's law is more likely to mention arbitration.

We apply a mixed-methods framework to examine the extent to which our argument explains the variation in domestic laws, comparing it against three alternative explanations for why governments consent to arbitration: in order to make credible commitments, in response to coercion, and in response to bureaucratic incentives. We first test these arguments using event history analysis, with two unique datasets on World Bank technical assistance and domestic investment laws. We find that the presence of a FIAS mission is an exceptionally strong predictor of domestic investment laws with arbitration clauses, even when controlling for lending and other IO involvement. Second, we illustrate how the causal mechanism works in a case study of the Kyrgyz Republic's 2003 investment law, which we select as a typical case.

In the next section, we elaborate our argument and compare it with existing explanations for investor-state arbitration. Then we discuss our research design and findings, and finally, our conclusions. 


\section{Argument: IO Analytic Institutions and Asymmetric Diffusion}

International organizations are often conceptualized as unitary actors, but in reality, many IOs are sprawling organizations composed of sub-units with different identities, purposes, and organizational cultures. Here we focus on analytic institutions, following Broome and Seabrooke (2012). Analytic institutions are specialist units within wider IOs that define policy problems and solutions, usually by defining indicators and best practices. Analytic institutions provide the tools through which IOs make states more legible, by replacing idiosyncratic local arrangements with benchmarked, coherent, and compatible national systems (Scott, 1998; Broome \& Seabrooke, $2007,2012)$. Their work embodies the notion of bureaucratic universalism, that is, bureaucracies are supposed to generate universal rules because technical knowledge is transferable across circumstances (Barnett and Finnemore, 2004, p. 39).

IO analytic institutions are important actors in the current 'ratings craze' (Cooley \& Snyder, 2015); many rankings, like the World Bank Doing Business indicators, emerge from IO analytic institutions. Therefore, analytic institutions have come under increased scrutiny in the growing research on rankings, indicators, and benchmarks (Best, 2017; Broome \& Quirk, 2015; Broome et al., 2018; Clegg, 2010; Cooley \& Snyder, 2015; Davis et al., 2012; Kelley \& Simmons, 2015, 2019; Merry et al., 2015). Much of the literature on IOs and ranking-based benchmarking focuses on how states respond to the indicators. Rationalist approaches suggest states respond strategically, either by paying attention only to the rankings that might inflict economic damage, such as credit ratings, or by 'teaching to the test' and targeting indicators to improve their scores without adopting new behaviors (Cooley \& Snyder, 2015, pp. 4-5). Approaches emphasizing socialization and reputational concerns find that ratings lead officials to internalize certain priorities or to exert influence through naming and shaming (Kelley \& 
Simmons, 2015, 2019). IO analytic institutions do more than create benchmarks, and we focus on a policy that is defined by an IO analytic institution as best practice, but not included in any benchmark or ranking, in order to study other means of influence.

Instead of benchmarks, we focus on policy templates written by IO analytic institutions. Templates, or policy documents that define international best practices, come in several forms. One form of template is a public text that governments are invited to use as the model for domestic legislation, like the model laws designed by the UN Commission on International Trade Law on issues like commercial arbitration (1985, updated 2006) and cross-border insolvency (1997).3 IOs also issue model texts for international treaties, like the model tax convention issued by the OECD Committee on Fiscal Affairs, which is the basis for most double taxation treaties (Sharman, 2012, p. 27). Templates can also take the form of guidelines or handbooks issued by IOs. For instance, since 1979 the OECD has regularly updated guidelines on transfer pricing to encourage standardization (Sharman, 2012, p. 26). The core trait of a template is that it identifies best practices, as defined by the IO analytic institution.

The process of constructing a template usually starts with collecting information on national policies. Deciding what information to collect necessarily advances certain values at the expense of others, as Vetterlein (2012) illustrates in her examination of debates within the World Bank on how to measure poverty. Analytic institutions define best practice by identifying or articulating a policy and then labelling this policy as the preferred solution to a common problem facing member states (Broome \& Seabrooke, 2012, p. 7). Deciding what counts as a policy problem and constructing policy solutions is the crux of analytic institutions' work. Examining how they diagnose problems and construct solutions can 'provide us with a stronger grasp of 
how IOs seek to influence and engineer change within their member states' (Broome \& Seabrooke, 2012, p. 5).

The ability of IO analytic institutions to influence member states rests on the IO's reputation and expert authority, which, in turn, rest on claims of universal technical knowledge (Barnett \& Finnemore, 2004; Halliday, Block-Lieb, \& Carruthers, 2010). IO templates or scripts are strategic devices that work to build an IO's legitimacy through rhetoric (Halliday et al., 2010). The effectiveness and legitimacy of a template or script is affected by its adoption, which can be thought of as 'a quantitative criterion (i.e. how many nations signed a convention) [and] a qualitative criterion (i.e. which nations have adopted global norms)' (Halliday et al., 2010, p. 82). An IO may use the adoption of a recommendation or template by many states or by particular states to bolster its legitimacy claims and validate its template.

An IO is not able to invoke the practice of powerful states or wide adoption in an instance of asymmetric diffusion. Asymmetric advice undermines an IO's rhetorical claims about universal best practice, which in turn undermines the credibility and legitimacy of an IO's recommendations. If it is damaging for an IO's legitimacy, why does asymmetric diffusion occur?

Examining the incentives and constraints produced by an IO's institutional environment can explain many puzzling aspects of IO behavior (Cooley and Ron, 2002, p. 6), including asymmetric diffusion. Cooley and Ron (2002, p. 6) argue that 'dysfunctional organizational behavior is likely to be a rational response to systematic and predictable institutional pressures'. They highlight how shifts in donor strategies toward competitive contract tenders, one-year renewable contracts, and increased reliance on consultants contribute to dysfunctional IO behavior (Cooley and Ron, 2002, pp. 6-13). When an IO or analytic institution faces contract or 
funding renewal pressure, it has incentives to be responsive to donor priorities and may not be designed with channels for feedback from recipient states or contestation over its policy recommendations; these characteristics enable asymmetric diffusion. Growing IO reliance on consultants also discourages change: 'the logic of consultancies is that there is a high premium on getting future contracts, which means that policy recommendations should not "rock the boat"” (Seabrooke and Sending, 2019, p. 4).

Identifying who participates in defining best practice, another aspect of an IO's institutional environment, can also help to explain the persistence of asymmetric diffusion. In their research on bankruptcy law, Block-Lieb and Halliday (2017, pp. 4, 10) find that 'how international commercial law is made influences what law is made' and 'the who of lawmaking is inseparable from the how'. Similarly, Kentikelenis and Seabrooke (2017, p. 1071) 'zoom in on which scientific and political actors are included in, or excluded from, global normmaking processes'. They argue that focusing on power asymmetries can also 'explain instances of widespread script institutionalization, despite contention in the countries affected and from other international organizations involved' (Kentikelenis and Seabrooke, 2017, pp. 1083-4).

Asymmetric diffusion is likeliest in contexts where policy feedback from weaker actors is limited.

Even when they contain 'contested policy ideas as best practices', the templates written by IOs 'achieve legitimacy — and thereby policy traction — by piggybacking on the status of the organizations that produce them as expert evaluators' (Broome et al., 2018, p. 516). Templates can be tied to IO lending or structural power, but in this paper we seek to isolate the influence of templates from coercive means of influence available to IOs, such as future lending, loan conditionality, or blacklisting. We study a policy that has never been a condition for a loan 
or grounds for blacklisting, in order to focus on subtler means of influence. To examine how templates spread, we build on earlier scholarship that presents IOs as 'teachers' (Finnemore, 1993; Jacoby, 2001) and actors that validate and promote certain norms (Park \& Vetterlein, 2010). We focus on one means of influence: technical assistance provided by IO analytic institutions. The next section outlines how the World Bank defined best practice in domestic investment laws and how a part of the World Bank disseminates those practices through technical assistance.

\section{The World Bank's Definition of Best Practices in Domestic Investment Laws}

The World Bank is the only IO that has ever recommended governments provide access to investor-state arbitration in their domestic investment laws. In 1965, the World Bank Executive Directors released a report that mentioned governments could provide access to investor-state arbitration in their domestic laws (Parra, 2017, p. 81). The Directors issued the 1965 report to increase awareness of a multilateral treaty drafted by the World Bank which creates a procedure and secretariat to administer investor-state arbitration proceedings. 4 In the 1960s and 1970s, this secretariat started collecting the domestic investment laws of developing countries (Parra, 2017, pp. 139-141).

In the mid-1980s, World Bank officials began working to define best practices for domestic investment laws. First a survey of domestic investment laws was conducted (Parra, 1992). Then Guidelines on the Treatment of Foreign Direct Investment were drafted; a purpose of these Guidelines was to serve as a template of best practices for domestic investment laws, and the Guidelines mention investor-state arbitration (Shihata, 1991, p. 499; Shihata, 1993).

4 The Convention on the Settlement of Investment Disputes Between States and Nationals of Other States, which set up the International Centre for Settlement of Investment Disputes (ICSID). 
Also during the 1980s, FIAS, a new agency within the World Bank Group, was created. FIAS, a small organization, has been renamed and restructured, but its mandate has remained the same: 'to provide advice on host country policies that affect the flow of productive private investment' (FIAS, 2006, p. 8). FIAS is the analytic institution that we focus on, and in particular, their domestic investment law advice. The purpose of FIAS's investment law reform work is to 'help countries attract and retain foreign investment by recommending legislative reforms' (FIAS, 2006, p. 20).

The purpose and procedure of this technical assistance have remained the same over time. The 2006 Annual Report notes that 'FIAS advice on investment legislation starts with a review of existing or draft legislation, in which we identify eventual flaws and inconsistencies and offer concrete recommendations based on "international best practices"” (FIAS, 2006, p. 20). Officials also use best practice to describe their work: 'I think the value added of the World Bank is that we work all around the world [...] so we can get all these good practices that have been working elsewhere'.5

The initial best practice template was the 1992 Guidelines, mentioned above. Poulsen (2015, p. 79), writing about the 1990s, argues that FIAS's 'main policy was to focus on enshrining the World Bank Guidelines into domestic laws'. Since then, the Guidelines have been extended into a longer handbook. The current FIAS template, the 2010 Investment Law Reform Handbook, states:

Good practice is for the investment code to recognize/guarantee that disputes arising in connection with investment $[\ldots]$ will be settled promptly through consultations and negotiations between the parties to the dispute, or through procedures for arbitration in accordance with the

5 Interview, FIAS A, 2019. 
host country's international commitments or through other arbitration procedures acceptable to both parties. It is not advisable to include in the provision a mandatory period of negotiations before filing for arbitration (FIAS, 2010, p. 53).

The Handbook urges governments to provide access to arbitration. In interviews, FIAS officials provided further explanation, which was consistent with the Handbook:

To put things in perspective I think we advocate for ISDS [investor-state dispute settlement] as a good international practice. Also to ensure alignment with IIAs [international investment agreements].6

I think the broad idea regarding investor rights is to ensure [the law] either gives rights that are higher than those $[\ldots]$ already available in IIAs or BITs [bilateral investment treaties], or to match them. That is the core message from our side. [...] We say that it is always better to have your domestic law in alignment with your international laws that you have already accepted like 15-20 years ago in the form of a BIT.7

We are not arguing that FIAS officials instruct national officials to insert access to arbitration in their domestic laws; rather, that their framing of arbitration influences how national officials see it. National officials are likely to conclude that providing arbitration access is best practice and that its benefits will likely outweigh the risks. In fact, FIAS officials report that they often have to reassure states that are afraid of arbitration cases: 'we have to tell them that states have won more times in ISDS cases than have private investors.' 8 This leads to our hypothesis: Receiving technical assistance on investment law reform from FIAS increases the probability that a state will consent to arbitration in its domestic investment laws.

6 Interview, FIAS A, 2019.

7 Interview, FIAS B, 2019.

8 Interview, FIAS B, 2019. 
If our hypothesis is supported, we will observe a relationship between governments receiving advice from FIAS and laws that mention arbitration, across a range of countries. Yet, how do we know that governments receive technical assistance first, and then start remaking their investment laws? In the sections below, we explore possible selection effects and sequencing.

\section{Selection: Who Asks for Technical Assistance?}

Formally, governments must ask FIAS to provide technical assistance. This leads to concerns about endogeneity and selection bias. Have governments already decided to embark on reforms to their investment laws when they ask FIAS for assistance?

Our interviews with FIAS officials and country officials suggest that FIAS technical assistance missions are initiated for a variety of reasons, most of which do not relate to the government's willingness to undertake policy change in hopes of attracting foreign investment. In other words, countries rarely self-select into assistance; they are selected because the World Bank is operating other projects there or because a donor suggests funding a project in that country. In fact, we have not been able to identify a single instance in which a government started work on a new domestic investment law and then asked FIAS for assistance.

In practice, the idea for FIAS assistance emerges externally, often through suggestions by officials in other arms of the World Bank Group. As one official put it:

We have other [World Bank] teams that are working on these areas, and then they say [to the government], 'Well now you have addressed this, you have to address the broader investment climate aspects, to ensure that you get the maximum benefit', and they refer us. The country makes the decisions though, to engage us.9

9 Interview, FIAS B, 2019. 
World Bank country offices also provide information to governments about the technical assistance services that the World Bank Group can provide:

The approach is, or should be, demand-driven and not supply-driven. However, of course, as I mentioned, the World Bank has local offices all around the world. And these local offices, their work is to keep our relationship with the government. They produce reports and analysis, they go to meetings with the government, to workshops [...] so the government, whenever they feel they need assistance on something, they can reach out to the World Bank colleagues in the region.10

Capacity-constrained governments face a complicated landscape with many donor agencies, IOs, and other actors; they are not necessarily aware of FIAS. World Bank country offices advertise or remind governments of available technical assistance. Moreover, FIAS advisory missions often overlap with World Bank lending operations. These countries do not embark on investment law reform and then contact FIAS; the assistance emerges as part of larger World Bank operations.

FIAS advisers are often invited to countries shortly after the end of armed conflict or in the early years after independence, as part of larger World Bank and donor programs in those countries. For instance, Sierra Leone's civil war raged until 2002, and by 2003, FIAS advisers were in-country. Similarly, FIAS began advisory work in Timor-Leste immediately after independence from Indonesia was restored in 2002 (See Table 1). FIAS strategy documents state that its 'priority clients' are 'fragile and conflict-affected situations, low-income countries, and Sub-Saharan Africa' (FIAS, 2014, p. 7).

Donors can also influence which countries receive assistance. FIAS is donor-funded and some donors earmark which countries they want the money to be used for; donors may even

10 Interview, FIAS A, 2019. 
allocate funds for specific types of technical assistance, including FIAS investment law reform work. An official gave the following hypothetical example: 'They say I allocate 40 percent of this project to business regulations, and then I allocate 20 percent to investment policy and then another 30 percent to sectors'.11 This is further evidence that although governments do formally invite FIAS to provide assistance, the impetus for investment law reform often does not come from them.

The countries that receive FIAS assistance are characterized by capacity constraints that make robust scrutiny of an IO template less likely. Broome and Seabrooke (2015, pp. 960-1) observe that states differ along two dimensions, policy capacity, defined as the ability to implement a policy, and policy space, defined as the range of thinkable policy options. These dimensions create four types of states: (I) lower-capacity rogue states, (II) lower-capacity states that are "eager to embrace global "best practice" policies without the capacity to adapt them to the local environment', (III) higher-capacity states innovating policies, and (IV) higher-capacity states involved in IO trainings (Broome and Seabrooke 2015, p. 961). When asymmetric diffusion occurs, the IO templates should appear most frequently (and perhaps only) in this second type of state, defined by eagerness to implement best practice and by capacity constraints that make scrutiny or adaptation less likely.

\section{Sequence: Technical Assistance as a Process}

We conceptualize technical assistance as a process; international actors bring with them a template of best practices, which are transmitted and translated in an iterative relationship.

FIAS projects on domestic law reform begin with the project being funded and an external consultant and local lawyer being hired. External consultants are often former

11 Interview, FIAS B, 2019. 
ambassadors or retired trade negotiators, or they have worked for international organizations.12 These consultants often work for FIAS repeatedly, and may work on drafting domestic investment laws in several countries.13 The consultant and possibly FIAS officials travel to the country for initial scoping exercises. There is a related diagnostic stage in which FIAS officials or consultants review relevant national laws, administrative processes, and investment treaties agreed by the country. One official described this stage succinctly: 'We review the law up against best practices'.14 Then there are consultations with 'stakeholders in the private and public sectors, to identify issues in the legal framework and build reform consensus'.15

The local lawyer usually writes the first draft of the new investment law, using the Investment Law Reform Handbook as a template as well as example clauses suggested by FIAS. Then, a draft of the law is sent to FIAS in Washington; FIAS reviews it and provides comments. FIAS officials emphasized that they do not write laws at any point, but they do provide detailed comments whenever there is a draft.16

In many governments, a working group is set up to discuss a new investment law. The timing, mandate, and composition of working groups vary, but international actors often participate. When FIAS is involved, the external consultant and local lawyer will participate. Officials from other IOs may participate, as well as representatives of foreign firms or industry groups, foreign law firms, and aid agency officials. For instance, the working group that drafted Kosovo's investment law (which did not include FIAS, because Kosovo is not a World Bank member) included representatives from the American aid agency USAID, the American

12 Interview, FIAS B, 2019.

13 Interview, Kyrgyz B, 2019.

14 Interview, FIAS B, 2019.

15 Interview, FIAS B, 2019.

16 Interview, FIAS A, 2019; Interview, FIAS B, 2019. 
Chamber of Commerce, and the Kosovo Chamber of Commerce.17 When FIAS is involved, the working group may send drafts of the law to FIAS in Washington for review. FIAS Annual Reports frequently report providing comments to a government in multiple years when a new investment law is being drafted.

The final step in most countries is parliamentary review and debate. Even in this step, external actors may have influence. For instance, the Bosnian investment law was preceded by a letter from the United Nations High Representative, who noted that the House of Representatives had 'removed the Draft Law from the proposed agenda' but that he believed doing so was 'against the best interest of Bosnia and Herzegovina'. Therefore, he wrote, 'I have decided to put into force the Law on the Policy of Foreign Direct Investment in Bosnia and Herzegovina'.18 This extreme case is a reminder that FIAS and other providers of technical assistance often work in contexts in which domestic deliberation may be limited or curtailed.

\section{Alternative Explanations}

With one exception (Poulsen, 2015), existing research on domestic investment laws is limited to policy reviews of state practices (UNCTAD, 2016; Bonnitcha, 2017) and legal analysis (Parra, 1997; Caron, 2010; Potestà, 2011; Hepburn, 2018). Yet many of the arguments advanced to explain why governments sign investment treaties with arbitration clauses may be relevant for why governments enact domestic investment laws with the same arbitration provisions. Therefore, we review three explanations for why governments sign investment treaties with arbitration provisions.

17 Kosovo official, personal communication, December 19, 2018.

18 Letter from Carlos Westendorp, High Representative for Bosnia and Herzegovina, to Slobodan Bijelic and Avdo Campara, 'Decision imposing the Draft Law on the Policy of Foreign Direct Investment in BiH', 3 May 1998. 
The first explanation is that developing countries are engaged in a rational competition for capital, and governments provide access to arbitration in order to increase the credibility of their commitments to investors and to compensate for weak institutions (Guzman, 1998; Elkins, Guzman, \& Simmons, 2006). If this explanation applies in the context of domestic investment laws, we should see a correlation between lower-quality domestic institutions and laws with arbitration access.

The second major explanation is power-based. Allee and Peinhardt (2014) find that access to arbitration in a bilateral treaty is determined by the degree of power asymmetry between the bargaining states. Since domestic laws do not emerge in bilateral bargaining contexts, we adapt this argument and identify two possible sources of coercion in domestic law drafting.

First, IOs may exert coercive influence. Gwynn (2016) argues that the structural power exercised by IOs is important to understand the spread of investor-state arbitration. We operationalize this type of coercive influence with explicit conditionality. If a new domestic investment law is a condition that must be met for a loan or loan disbursement from the World Bank, then coercion is at work. If we find a link between World Bank lending and domestic laws with arbitration, that would suggest our explanation needs to be revised for a more coercive one.

Second, foreign firms or other states may exert pressure on governments to change their laws. Some scholars find evidence that home states are lobbied by domestic firms who seek arbitration access (Allee \& Peinhardt, 2014; Maurer, 2013; Wellhausen, 2015) while others find less evidence of lobbying (Gertz, 2018; Poulsen, 2015; St John, 2018). We think that if firms lobby their host governments for access to arbitration, they are more likely to lobby for access to be written into their contracts. This is much easier than pushing for an overhaul of domestic 
legislation. Similarly, if another state seeks access to arbitration for their investors, they are likely to negotiate a treaty instead of pushing for new domestic legislation. Nevertheless, if this explanation is accurate, we should see a correlation between smaller markets and laws with arbitration access.

At first glance, these two alternate explanations, credible commitments and coercion, seem to have limited explanatory value regarding domestic investment laws. Figure 1 shows the distribution of states that have mentioned to arbitration in their domestic investment laws and those that have not, sorted on the quality of their domestic property rights institutions and their market size.19 While it is striking that no OECD state has ever mentioned arbitration in its domestic laws, the countries that have consented to arbitration are not clustered in any obvious way, when ordered on these two dimensions.

19 To measure property rights institutions, we use the Property rights index from the Varieties of Democracy data project (Coppedge et al., 2018, p. 237). For the GDP data, see Section 3. We use the average values for each variable over the period 1986-2015. 


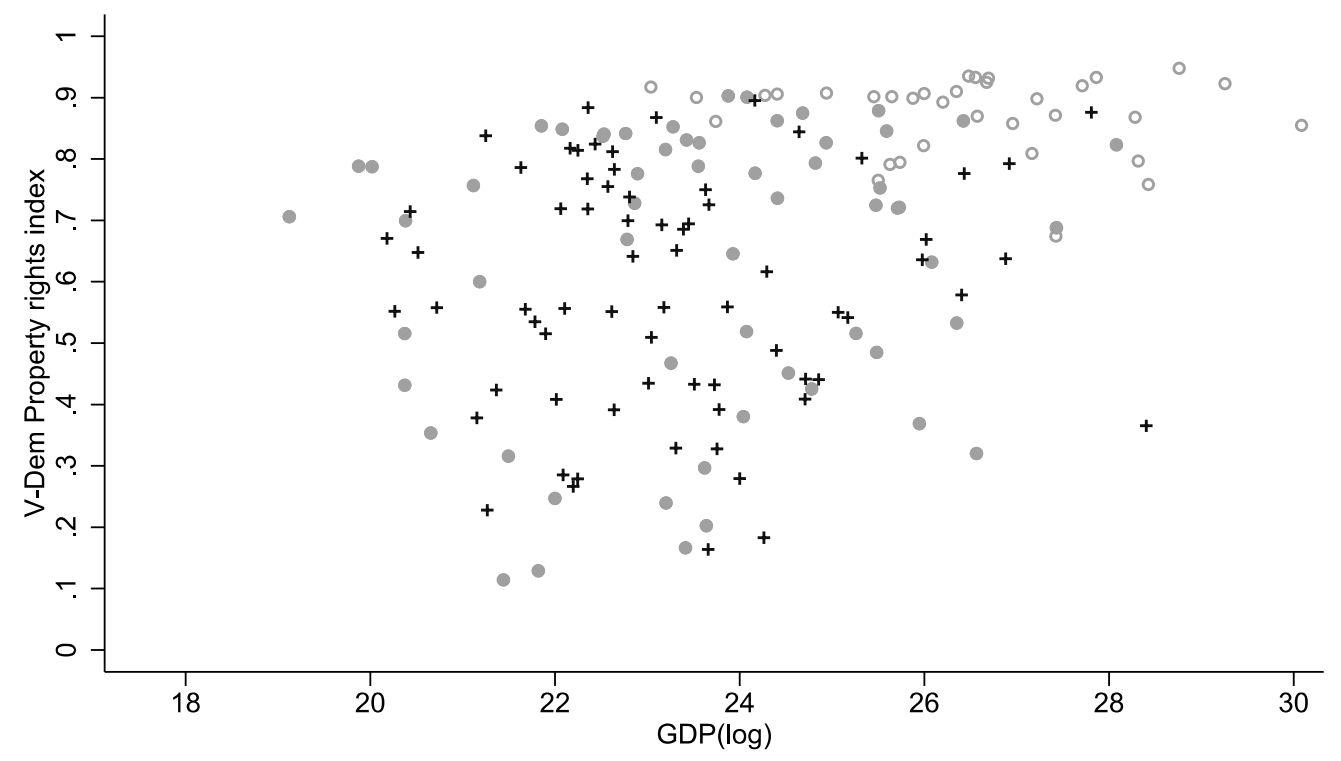

- No mention of abitration (non-OECD member)

- No mention of abritration (OECD member)

+ Mentions arbitration

Figure 1. Mention of arbitration in domestic laws, property rights institutions, and GDP (average values 1986-2015)

The third major explanation focuses on officials' perceptions of investment treaties. Poulsen (2015) argues that government officials initially underestimated the costs and overestimated the benefits of investment treaties. Jandhyala, Henisz, \& Mansfield (2011) argue that how government officials perceive treaties with arbitration changes over time. While in earlier decades officials signed investment treaties in hopes of attracting investment, by the 1990s, officials signed investment treaties because they had become an accepted norm.

We focus on the dynamic aspect of these explanations, that government officials can learn about investor-state arbitration and change their views over time. Poulsen and Aisbett (2013) show that once governments face their first investor-state arbitration claim, their propensity to sign investment treaties decreases significantly. If this explanation applies to 
domestic investment laws, we should see a correlation between fewer treaties or fewer arbitration claims faced, and laws with arbitration clauses.

In our analysis, we include indicators that capture each of these alternative explanations. To account for domestic institutions, we use measures that capture the quality of regulatory agencies and of government accountability; to account for potential coercion, we use World Bank lending data and measures of states' overall market size; and to account for potential learning effects, we use measures of actual exposure to arbitration. We comment on the independent effect of all these variables, but our primary interest is the explanatory value of FIAS technical assistance. 


\section{Research design and analysis}

\section{Quantitative analysis - establishing a link between FIAS and arbitration clauses}

Dependent variable: arbitration clauses in domestic investment laws

Our dependent variable is the time until adoption of a domestic investment law with access to arbitration, measured in days. We observe all World Bank member states, starting in 1986 when FIAS was established, or later if they joined the World Bank after 1986. Our event of interest is the passage of a domestic investment law with an arbitration clause.

We use two operationalizations: (I) laws that mention international arbitration at any arbitral fora, and (II) laws we are reasonably certain that tribunals would interpret as providing consent and direct access to arbitration, based on published legal interpretations and previous tribunal decisions on jurisdiction. All laws coded in category (II) will necessarily also be in category (I). The first measure is straightforward and replicable. The second is more meaningful because it attempts to isolate if a government thought it was providing foreign investors with access to arbitration, but it is also more subjective. We discuss both operationalizations in Appendix A, including the legal scholarship and decisions we used to code category (II).20 Within our sample period (1986-2015), we identify 74 laws coming into force that mention international arbitration, of which 42 laws are coded as providing probable consent to arbitration at some point in time.21 Figure 2 shows these developments over time.

20 Appendix A reproduces the dispute resolution clause of each law we coded, with an explanation of our coding and the sources used.

21 A few countries have domestic investment laws with arbitration clauses that came into force before 1986: Egypt (1974), Sri Lanka (1978) and the Republic of the Congo (1982). As discussed in Appendix A, we exclude these countries from our sample, even though we have anecdotal evidence connecting these provisions to the presence of external advisers, including World Bank officials. To the best of our knowledge, Egypt's law is the first investment law that provides consent to investor-state arbitration, but Fatouros (1962, p. 186-187) mentions that a handful of national petroleum laws included provisions on arbitration and notes a 1953 Greek law that outlines a procedure for investor-state arbitration. 


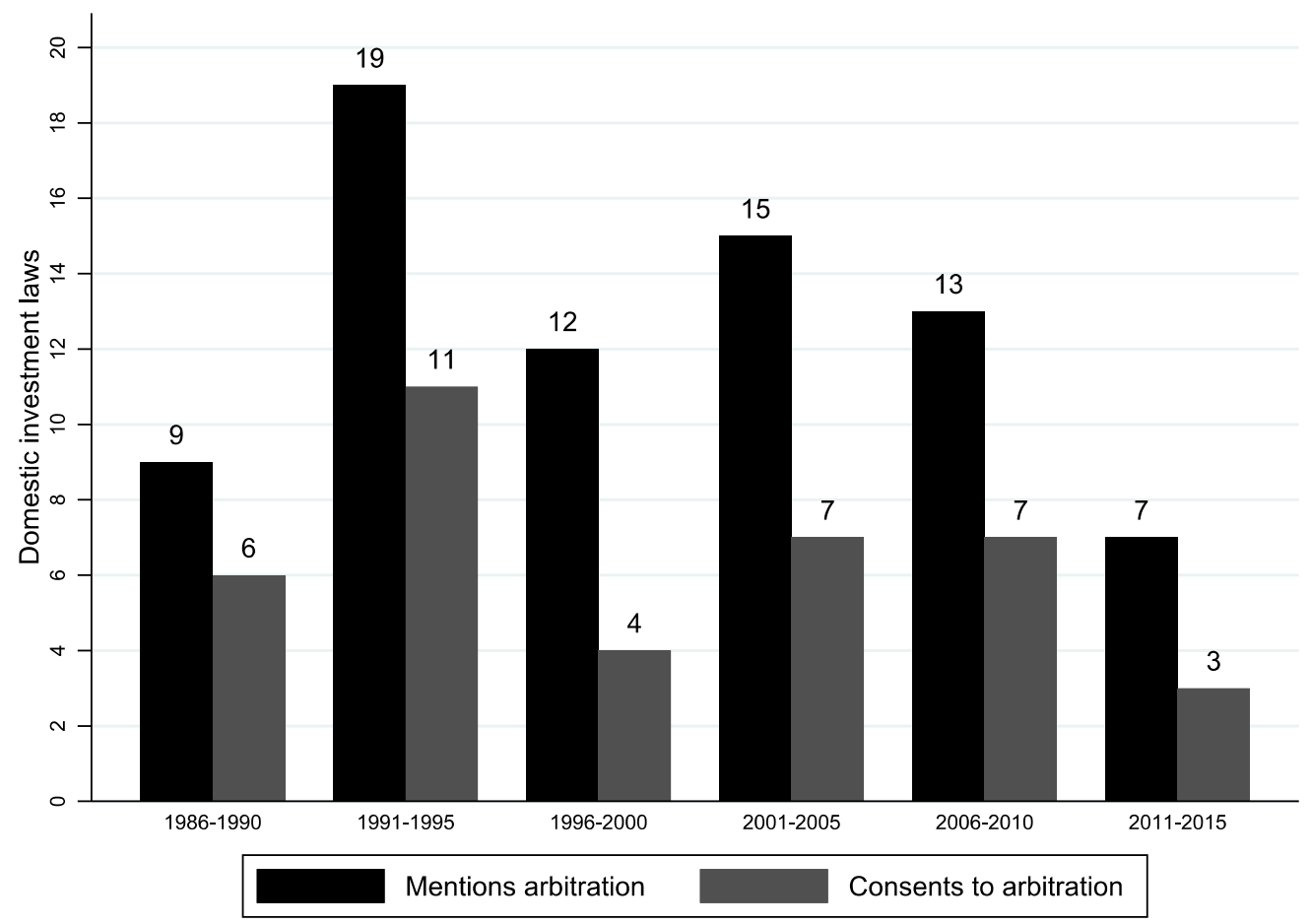

Figure 2. Developments in domestic investment laws enacted, five-year intervals, authors' own coding

Independent Variable: FIAS advice on reforming domestic investment laws

Our independent variable is a binary measure of the in-country presence of FIAS technical advisory missions. We coded the presence of a FIAS mission, using FIAS's annual reports, which list all advisory projects finalized in any given year.22 The annual reports distinguish different types of advisory activity, which enables us to single out FIAS projects that gave advice on domestic investment laws. Since drafting and implementing legislation is a process that can take years, we employ two versions of our independent variable. The first measures whether

22 We used FIAS's annual reports to identify technical assistance missions going back to 1999, and an internal evaluation of FIAS's first 13 years of operation to identify technical assistance missions from 1986 to 1998 (World Bank, 1995; World Bank, 2004, pp. 33-36). The annual reports are available through the World Bank's document portal, for instance (World Bank, 2000b, 2001). Interviews with FIAS officials confirmed that all projects are listed in their annual reports (Interview, FIAS A, 2019; Interview, FIAS B, 2019). 
FIAS finalized a project on that country's investment law in any of the previous three years, and the second, in any of the previous five years. So, when FIAS reports to have concluded an advisory project on domestic legal reform in Afghanistan in 2004, the first version of our variable is coded as 1 from 2004-2006, while the second version is coded as 1 for 2004-2008.

Figure 3 shows the distribution of completed FIAS advisory projects on domestic investment laws over time. The peak of advisory activity occurred in the late 1990s, with 18 reform projects on domestic investment laws completed in 1998 and 13 projects in 2000. While the number of projects fluctuates, FIAS's advice to states has remained consistent over time: providing access to arbitration in domestic law is best practice.

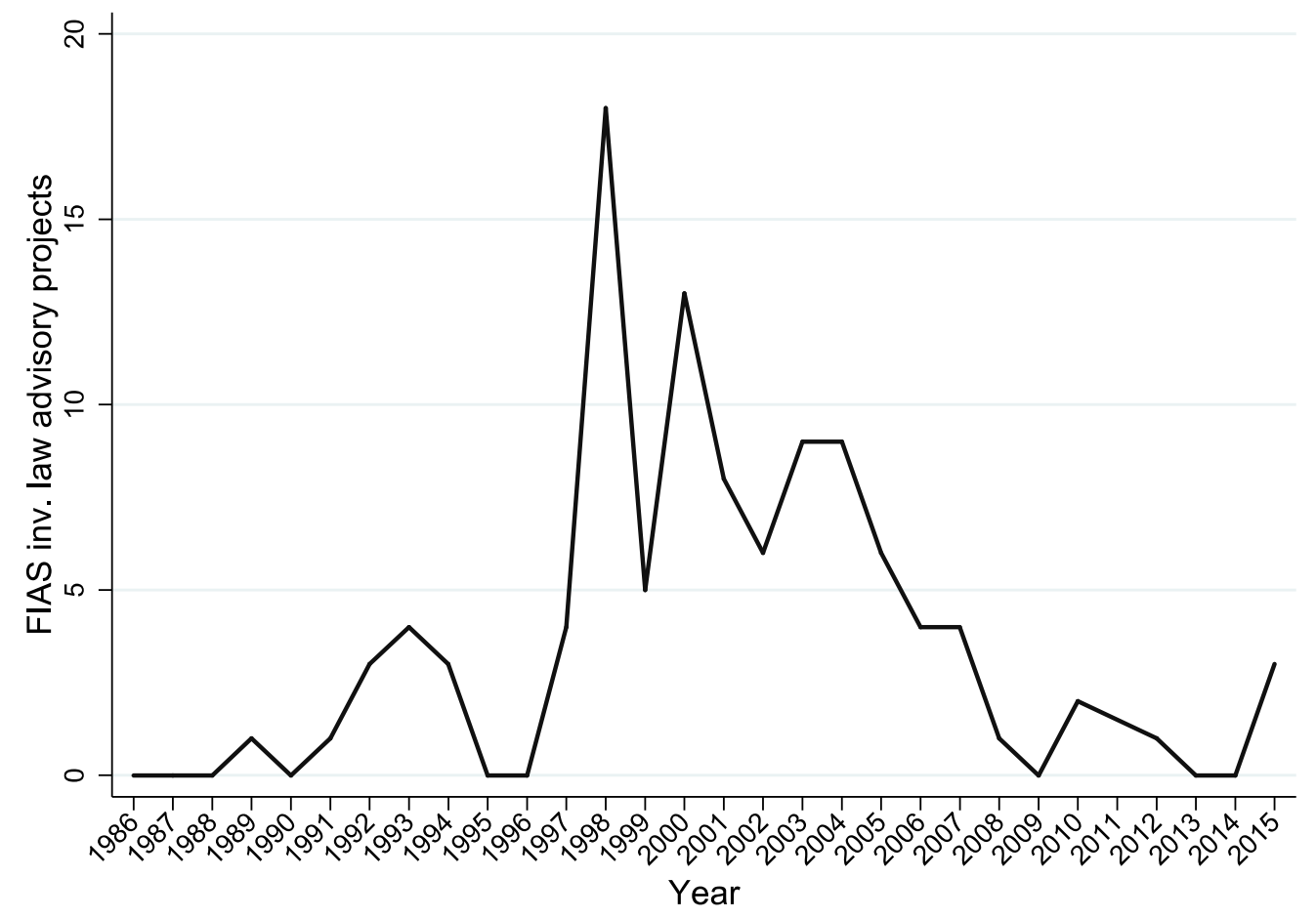

Figure 3. Completed FIAS advisory projects on domestic investment law reform, authors' own coding 
Analysis

Before we present the results from our event history analysis, we present the bivariate link between FIAS technical assistance and arbitration clauses in domestic investment laws. Table 1 lists all countries that have received FIAS technical advice or passed an investment law that mentions or consents to arbitration between 1986 and 2015.23

The link between FIAS and investment-law-making is striking. Of the 74 World Bank member states that have passed an investment law mentioning or consenting to arbitration after 1986, 30 countries received investment law advice from FIAS prior to passing the law (grey rows). For the large majority of these countries (27 of 30), it took less than three years from FIAS's previous advisory project until they passed their investment laws. Moreover, almost 50 percent (30/65) of the states that received investment law advice from FIAS included arbitration in their laws. That is remarkably high, given the potential for domestic opposition to arbitration clauses and given the administrative and political hurdles to passing legislation.

\begin{tabular}{lllll}
\hline Country & $\begin{array}{l}\text { FIAS advisory } \\
\text { mission completed }\end{array}$ & $\begin{array}{l}\text { Law mentioning } \\
\text { arbitration }\end{array}$ & $\begin{array}{l}\text { Law consenting } \\
\text { to arbitration }\end{array}$ & $\begin{array}{l}\text { Time from last FIAS } \\
\text { mission to law }\end{array}$ \\
\hline Afghanistan & 2004 & 2005 & 2005 & 1 year \\
\hline Albania & & 1993 & 1993 & \\
\hline Algeria & & 1993 & & 2013 \\
\hline Armenia & $1999 ; 2000 ; 2003$ & & 1990 & \\
\hline Azerbaijan & $2003 ; 2005$ & 1992 & & \\
\hline Belarus & & 2013 & years \\
\hline Benin & & 1990 & 1995 \\
\hline Bhutan & $2002 ; 2005$ & 1990 & \\
\hline Bolivia & 2002 & 1998 & \\
\hline Bosnia and Herzegovina & $1998 ; 2015$ & 1995 & \\
\hline Burkina Faso & & & \\
\hline
\end{tabular}

23 Table 1 shows a subset of the states we observe in our analysis, which includes all World Bank member states except the four that provided consent prior to 1986, as discussed in Appendix A. 


\begin{tabular}{|c|c|c|c|c|}
\hline Burundi & & 2008 & 2008 & \\
\hline Cabo Verde & & 1993 & 1993 & \\
\hline Cambodia & 1994; 2002; 2004 & 1994 & & 0 years \\
\hline Cameroon & & 1990 & 1990 & \\
\hline Central African Republic & & 2001 & & \\
\hline Chad & & 2008 & & \\
\hline China & 1998 & 1988 & & \\
\hline Colombia & & 2000 & & \\
\hline Comoros & 2006 & & & \\
\hline Costa Rica & 1998 & & & \\
\hline Côte d'Ivoire & & 1995 & 1995 & \\
\hline \multicolumn{5}{|c|}{ Dem. People's Rep. of Korea } \\
\hline Dem. Rep. of the Congo & $2001 ; 2002$ & 2002 & 2002 & 0 years \\
\hline Dominican Republic & 1998 & & & \\
\hline Ecuador & & 1997 & & \\
\hline El Salvador & $1994 ; 1998$ & 1999 & 1999 & 1 year \\
\hline Equatorial Guinea & $1992 ; 1993$ & & & \\
\hline Fiji & $1998 ; 2004$ & 2004 & & 0 years \\
\hline Gambia & & 2010 & 2010 & \\
\hline Georgia & & 1996 & 1996 & \\
\hline Ghana & 1993 & 1994 & 1994 & 1 year \\
\hline Guinea & & 1987 & 1987 & \\
\hline Guinea-Bissau & $\begin{array}{l}\text { 1997; 1998; 2006; } \\
2010\end{array}$ & & & \\
\hline Guyana & 2004 & 2004 & 2004 & 0 years \\
\hline Honduras & & 2011 & 2011 & \\
\hline Hungary & 1991 & & & \\
\hline Indonesia & $2006 ; 2007$ & 2007 & & 0 years \\
\hline Iran & & 2002 & & \\
\hline Iraq & & 2006 & & \\
\hline Jordan & 2003 & 1994 & 1994 & \\
\hline Kazakhstan & 1998 & 1994 & 1994 & \\
\hline Kenya & $2000 ; 2005$ & & & \\
\hline Kuwait & $1998 ; 2000$ & 2013 & & 13 years \\
\hline Kyrgyzstan & 1998; 1999; 2001 & 2003 & 2003 & 2 years \\
\hline Liberia & 2010 & 2010 & 2010 & 0 years \\
\hline Libya & & 2010 & & \\
\hline Lithuania & 1999 & 1999 & 1999 & 0 years \\
\hline Macedonia & 2000 & & & \\
\hline Madagascar & $2007 ; 2008$ & 2008 & 2008 & 0 years \\
\hline Malawi & 1992 & 1992 & & \\
\hline Maldives & 2003 & & & \\
\hline
\end{tabular}




\begin{tabular}{|c|c|c|c|c|}
\hline Mali & 2012 & 1991 & 1991 & \\
\hline Marshall Islands & 1998 & & & \\
\hline Mauritania & $1999 ; 2002$ & 2002 & 2002 & 0 years \\
\hline Micronesia & 2000 & & & \\
\hline Moldova & 2004 & 2004 & & 0 years \\
\hline Mongolia & 1998; 2001; 2003 & 2013 & 2013 & 10 years \\
\hline Montenegro & & 2011 & & \\
\hline Morocco & 2001 & & & \\
\hline Mozambique & & 1993 & & \\
\hline Namibia & 1992 & 1990 & & \\
\hline Nepal & & 1992 & 1992 & \\
\hline Nicaragua & 1998 & 2000 & 2000 & 2 years \\
\hline Niger & & 1989 & 1989 & \\
\hline Nigeria & & 1995 & 1995 & \\
\hline Oman & & 1994 & & \\
\hline Palau & $2001 ; 2003$ & & & \\
\hline Panama & 2002 & & & \\
\hline Papua New Guinea & 1989 & 1992 & & 3 years \\
\hline Paraguay & & 1992 & & \\
\hline Qatar & 2000 & 2000 & & 0 years \\
\hline Romania & 1998 & & & \\
\hline Russia & 1994; 1998; 2000 & 1999 & & 1 year \\
\hline Rwanda & 1998 & 2015 & & 17 years \\
\hline Sao Tome and Principe & 2001 & & & \\
\hline Saudi Arabia & 2001 & & & \\
\hline Sierra Leone & $1997 ; 2003$ & 2004 & 2004 & 1 year \\
\hline Slovakia & 2000 & & & \\
\hline Solomon Islands & $\begin{array}{l}\text { 1997; 2000; 2004; } \\
2005 ; 2006\end{array}$ & 2005 & & 0 years \\
\hline Somalia & & 1987 & 1987 & \\
\hline South Sudan & & 2009 & 2009 & \\
\hline Sudan & & 2013 & & \\
\hline Suriname & 2005 & & & \\
\hline Swaziland & 1997 & & & \\
\hline Syria & $2004 ; 2007$ & 2007 & 2007 & 0 years \\
\hline Tajikistan & & 2007 & & \\
\hline Tanzania & $1999 ; 2000$ & 1997 & & \\
\hline Timor-Leste & $2003 ; 2004$ & 2005 & & 1 year \\
\hline Togo & & 1989 & 1989 & \\
\hline Tonga & 2000 & 2002 & & 2 years \\
\hline Turkey & 2000,2003 & 2003 & & 0 years \\
\hline Uganda & $1998 ; 2000$ & 1991 & & \\
\hline
\end{tabular}




\begin{tabular}{|c|c|c|c|c|}
\hline Ukraine & 1998 & & & \\
\hline Uzbekistan & & 1998 & & \\
\hline Venezuela & & 1999 & & \\
\hline Vietnam & 1993 & & & \\
\hline Yemen & 2007 & 2010 & 2010 & 3 years \\
\hline Zambia & $1993 ; 2004$ & 2006 & & 2 years \\
\hline
\end{tabular}

Table 1. World Bank member states that have received FIAS advice and/or enacted laws with an arbitration clause between 1986-2015, authors' own coding

Since our dependent variable is measured as time until law adoption, and many of the country spells we observe are right-censored (i.e., the country in question never mentioned or consented to arbitration in a domestic investment law), we use event history analysis (BoxSteffensmeier \& Jones, 2004). Event history models estimate hazard rates, defined as the rate of occurrence of an event - in our case mention of or consent to arbitration - which is appropriate for making inferences about the duration of events in the face of right-censoring.

Moreover, using the event history framework is a good estimation strategy to incorporate time dependence in analyses of law adoption or diffusion (Strang, 1991). We estimate semiparametric Cox proportional hazard models that leave the duration dependence unspecified, because we have no assumptions about the shape of the time baseline hazard (Box-Steffensmeier \& Jones, 2004, p. 47), and because faulty specification of duration-dependency can bias inferences (Golub, 2008). The Cox model assumes that the effects of covariates do not vary with time (the proportional hazard assumption). Tests indicate that none of the covariates in our models violate this assumption.24

Our analysis begins in 1986, the year FIAS became operational within the World Bank, and includes investment laws passed until 2015. Our unit of analysis is country-year, and we 24 We used Schoenfeld residuals (stphtest in STATA) to test the proportionality for each covariate. 
observe all World Bank member states (except the three countries that passed domestic laws with arbitration clauses before 1986). Countries exit our sample on the day they pass a domestic investment law with an arbitration clause. 25 For countries that passed multiple laws between 1986 and 2015, we let them exit on the day they passed their first law with an arbitration clause. All models are estimated using robust standard errors clustered on countries and using the Efron method for handling tied events (Hertz-Picciotto \& Rockhill, 1997).

As discussed in the alternative explanations section, there are other explanations for why states include arbitration clauses in their domestic laws. Some of these factors may also confound the relationship between FIAS advice and domestic investment laws.

First, because we expect countries with well-developed domestic institutions to be less likely both to seek technical assistance from FIAS and to enact domestic investment laws, we use the Rigorous and impartial public administration variable from the Varieties of Democracy (VDem) data project (Coppedge et al., 2018, p. 159) to control for the quality of regulatory agencies. For similar reasons, we control for the strength of civil society and general government accountability. We use the Accountability index from V-Dem, which captures civil society's and the media's oversight over government processes, as well as vertical and horizontal checks on the executive (Coppedge et al., 2018, pp. 223-224).

To control for the fact that larger, more developed economies should be less likely to solicit technical assistance from the World Bank and less likely to give foreign investors preferential treatment, we control for countries' market size (using the log of GDP) and level of development (using the log of GDP per capita).26 Since newly independent countries and post-

25 For laws where we have not found records of the exact date of passage, we use the year midpoint, July 1.

26 These data are taken from the International Political Economy Data Resource (Graham \& Tucker, 2019), who use Penn World Tables data to supplement missing values in the World Bank's economic data. See:

https://dataverse.harvard.edu/dataset.xhtml?persistentId=doi:10.7910/DVN/X093TV. 
conflict countries are more likely both to seek technical assistance and to adapt their legislation to facilitate inflows of private capital, we introduce two controls: the log of the number of years since a country became independent, 27 and the log of regime durability.28 To control for the learning effect associated with facing arbitration claims, we control for the cumulative number of arbitration claims a state has faced, and the cumulative number of investment agreements with arbitration clauses that a state has signed.29 To control for the fact that enacting investment laws might be linked to structural power or coercion from the World Bank, we control for the log of annual International Bank for Reconstruction and Development (IBRD) loans. 30 Summary statistics for all variables, including bivariate correlations between the independent variables, are reported in Appendix B.

${ }_{27}$ We used The World Factbook from the Central Intelligence Agency to identify year of independence. See: https://www.cia.gov/library/publications/resources/the-world-factbook/.

28 To measure regime durability, we use data on the number of years since the most recent regime change from the Polity IV Project (Marshall, Gurr, \& Jaggers, 2018, p. 17).

${ }_{29}$ We compute the cumulative count of arbitration cases and investment agreements by using the list of publicly known claims and agreements available on UNCTAD's investment policy hub, see:

https://investmentpolicyhub.unctad.org. UNCTAD's IIA content mapping allows us to exclude agreements without arbitration clauses from our count.

30 These data are taken from the World Bank’s World Development Indicators. See:

https://datacatalog.worldbank.org/dataset/world-development-indicators. 


\begin{tabular}{|c|c|c|c|c|c|c|}
\hline & \multicolumn{3}{|c|}{ DV: Time-to-mention } & \multicolumn{3}{|c|}{ DV: Time-to-consent } \\
\hline & Model 1 & Model 2 & Model 3 & Model 4 & Model 5 & Model 6 \\
\hline \multirow[t]{2}{*}{ FIAS, previous 3 yrs. } & & $7.549^{* * *}$ & & & $7.971 * * *$ & \\
\hline & & {$[4.267,13.355]$} & & & {$[3.828,16.594]$} & \\
\hline \multirow[t]{2}{*}{ FIAS, previous 5 yrs. } & & & $6.407 * * *$ & & & $6.703^{* * *}$ \\
\hline & & & {$[3.693,11.117]$} & & & {$[3.194,14.066]$} \\
\hline \multirow[t]{2}{*}{ Rigorous and imp. adm. } & 0.836 & 0.875 & 0.877 & 0.914 & 0.918 & 0.915 \\
\hline & {$[0.630,1.108]$} & {$[0.660,1.159]$} & {$[0.666,1.157]$} & {$[0.613,1.364]$} & {$[0.604,1.396]$} & {$[0.608,1.379]$} \\
\hline \multirow[t]{2}{*}{ Accountability } & 1.286 & 1.061 & 1.063 & 1.410 & 1.196 & 1.178 \\
\hline & {$[0.817,2.023]$} & {$[0.688,1.637]$} & {$[0.686,1.650]$} & {$[0.782,2.542]$} & {$[0.654,2.186]$} & {$[0.650,2.134]$} \\
\hline \multirow[t]{2}{*}{ GDP $(\log )$} & 1.039 & 1.097 & 1.096 & 0.890 & 0.928 & 0.917 \\
\hline & {$[0.868,1.243]$} & {$[0.922,1.305]$} & {$[0.916,1.311]$} & {$[0.713,1.111]$} & {$[0.741,1.160]$} & {$[0.731,1.150]$} \\
\hline \multirow[t]{2}{*}{ GDP per capita (log) } & $0.665^{* *}$ & $0.688^{*}$ & $0.680 * *$ & $0.543^{* *}$ & $0.582^{* *}$ & $0.575^{* *}$ \\
\hline & {$[0.448,0.985]$} & {$[0.473,1.001]$} & {$[0.462,1.000]$} & {$[0.309,0.955]$} & {$[0.359,0.945]$} & {$[0.346,0.956]$} \\
\hline \multirow[t]{2}{*}{ Time since indep. $(\log )$} & $0.675 * *$ & $0.778^{*}$ & $0.780 *$ & 0.831 & 0.947 & 0.963 \\
\hline & {$[0.494,0.923]$} & {$[0.583,1.037]$} & {$[0.582,1.044]$} & {$[0.583,1.187]$} & {$[0.679,1.322]$} & {$[0.688,1.347]$} \\
\hline \multirow[t]{2}{*}{ Regime durability (log) } & 1.026 & 1.039 & 1.046 & 1.117 & 1.165 & 1.172 \\
\hline & {$[0.830,1.268]$} & {$[0.839,1.285]$} & {$[0.844,1.297]$} & {$[0.834,1.495]$} & {$[0.858,1.582]$} & {$[0.862,1.594]$} \\
\hline \multirow[t]{2}{*}{ Arbitration claims, cum. } & $0.800 *$ & 0.864 & 0.867 & 1.011 & 1.038 & 1.043 \\
\hline & {$[0.637,1.005]$} & {$[0.703,1.061]$} & {$[0.702,1.071]$} & {$[0.915,1.118]$} & {$[0.972,1.107]$} & {$[0.976,1.115]$} \\
\hline \multirow[t]{2}{*}{ IIAs signed, cum. } & 0.991 & 0.989 & 0.989 & $0.977 *$ & $0.974 *$ & $0.974 *$ \\
\hline & {$[0.978,1.004]$} & {$[0.975,1.004]$} & {$[0.975,1.004]$} & {$[0.953,1.001]$} & {$[0.947,1.002]$} & {$[0.947,1.002]$} \\
\hline \multirow[t]{2}{*}{ IBRD loans (log) } & 1.006 & 1.007 & 1.006 & 0.994 & 1.007 & 1.003 \\
\hline & {$[0.958,1.055]$} & {$[0.968,1.048]$} & {$[0.965,1.049]$} & {$[0.918,1.075]$} & {$[0.948,1.069]$} & {$[0.942,1.068]$} \\
\hline Spells (\# of countries) & 156 & 156 & 156 & 156 & 156 & 156 \\
\hline Events (\# of consents) & 70 & 70 & 70 & 35 & 35 & 35 \\
\hline Obs. (country-years) & 3475 & 3475 & 3475 & 3989 & 3989 & 3989 \\
\hline$A I C$ & 623.258 & 582.661 & 586.743 & 321.059 & 298.594 & 301.742 \\
\hline
\end{tabular}

Table 2. Cox regression models: Mention of or consent to arbitration in domestic investment laws

A series of Cox regression models using our two dependent variables are presented in Table 2. Estimates are reported as hazard rates. A hazard rate of greater than one represents a positive effect on the odds of a country adopting a domestic law with arbitration, and a hazard rate of less than one represents a negative effect. Models 1-3 use time-to-mention of arbitration in domestic laws as their dependent variable, and models 4-6 use time-to-consent to arbitration. 
Models 1 and 4 include only the control variable set. When looking at the effect of the variables that capture the three alternative explanations for arbitration clauses in these two models, only the two learning variables - the cumulative count of arbitration claims (model 1) and the cumulative count of investment agreements (models 4-6) - seem to be linked with the adoption rate of domestic laws with arbitration. Increases in both variables (more cases; more agreements) are associated with a decrease in the rate of law adoption. Variables related to the quality of domestic institutions (regulatory agencies; accountability) and IO coercion (market size; IBRD loans) have no independent effect on the adoption of domestic investment laws with access to arbitration.

When looking at the effects of FIAS technical assistance, the results are unequivocal. Receiving technical assistance on domestic investment law reform is strongly and significantly associated with an increase in the adoption rate of domestic investment laws that mention or consent to arbitration. Holding all other variables constant, moving from not receiving FIAS advice on domestic legal reform to receiving FIAS advice increases the rate of adoption of laws with arbitration clauses by between 650 and 800 percent. Interestingly, the effect of FIAS advice is strongest regarding laws that consent to arbitration. 


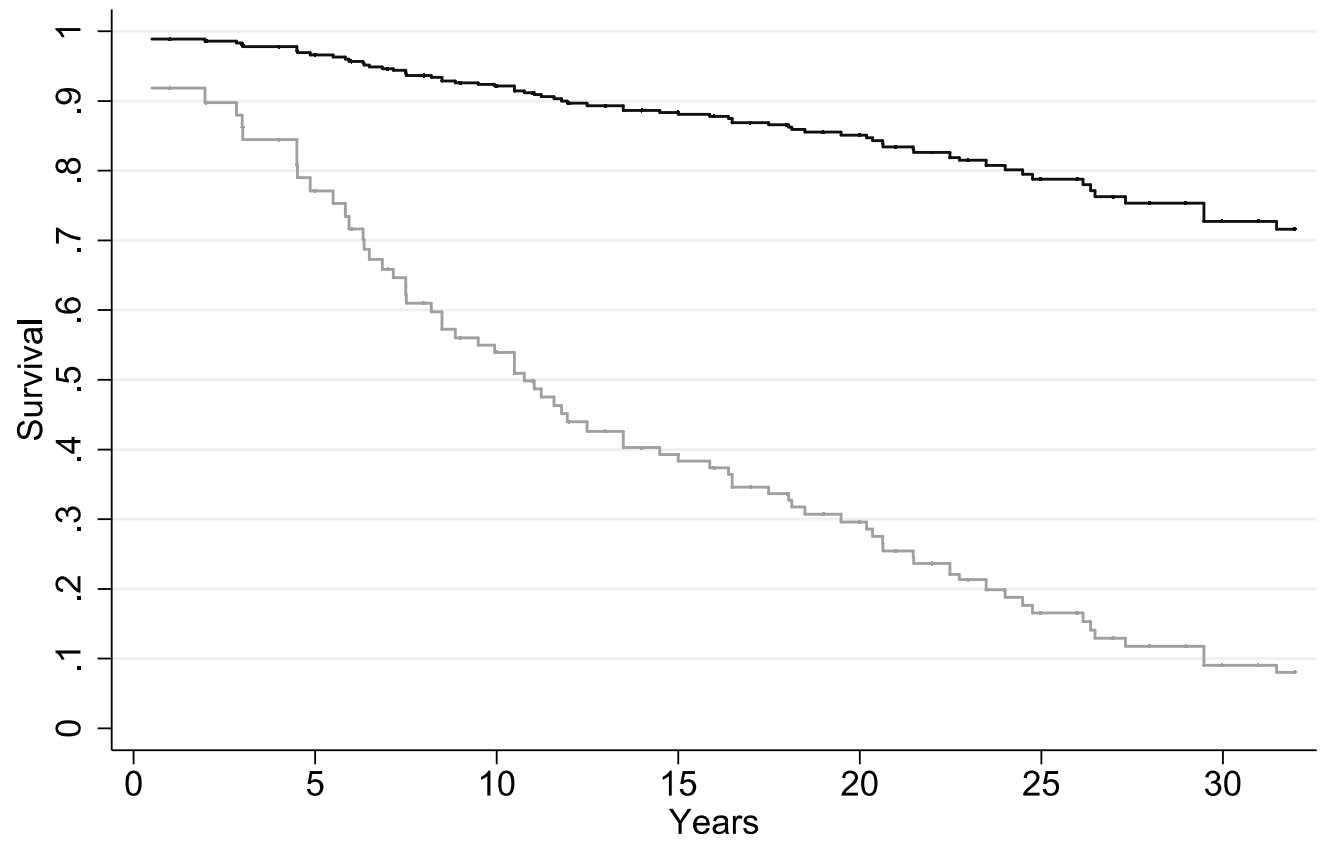

No FIAS mission

FIAS, previous 3 yrs.

Figure 4. Survivor function, mention of arbitration in domestic investment law (model 2 in Table 2)

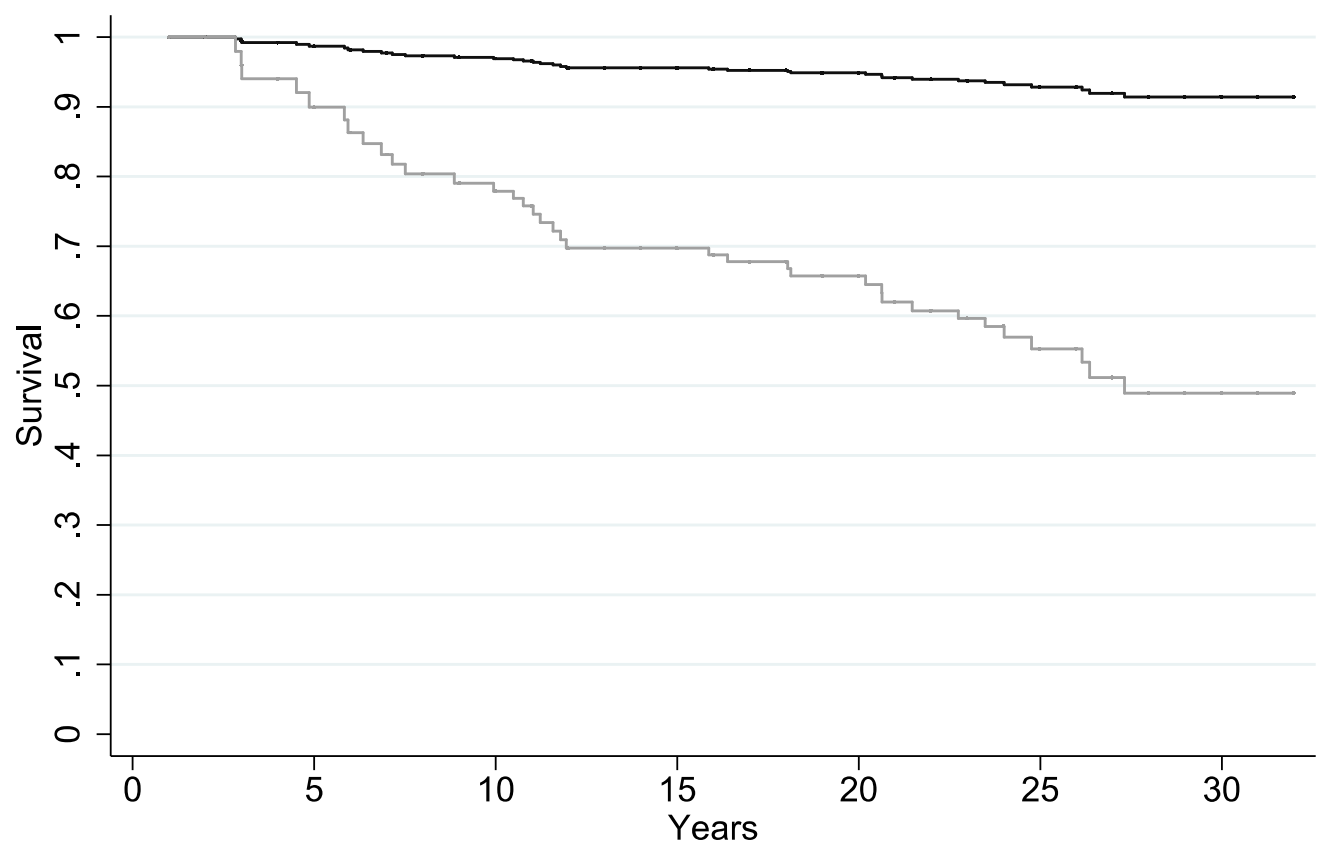

No FIAS mission

FIAS, previous 3 yrs.

Figure 5. Survivor function, consent to arbitration in domestic investment laws (model 4 in Table 2) 
Figures 4 and 5 illustrate this relationship by comparing the survivor functions for countries that have received FIAS advice on domestic legal reform in one of the previous 3 years with those that have not, while holding all other variables at their means. The diverging lines show the probability that a country in our sample that passed a domestic investment law mentioning or consenting to arbitration is markedly different for those states that received FIAS advice.

We conduct a series of robustness checks, including controlling for additional confounders, conducting placebo tests, trying alternative estimation methods, and running sensitivity tests. These robustness checks are described in Appendix C. The general tendency is that our results are robust to a broad range of checks.

\section{Qualitative analysis - the Kyrgyz Republic's 2003 Investment Law}

We conducted one case study to illustrate our hypothesis. Since our purpose was confirmatory or illustrative, we selected a typical case (Seawright \& Gerring, 2008, p. 297). A typical case is 'well explained by an existing model' and is used to better explore the causal mechanisms at work in the theorized relationship (Seawright \& Gerring, 2008, p. 299). A number of cases are well explained by our model; Table 1 above lists 23 countries that passed a new law providing consent to arbitration within two years of receiving FIAS advice. Any of those countries could have been selected as typical cases. We selected the Kyrgyz Republic, which received technical assistance from FIAS in 1998, 1999, and 2001, and then passed an investment law with consent to arbitration in 2003. 


\section{Context}

As we would expect of a typical case, the Kyrgyz government had low bureaucratic capacity, weak property rights institutions, and little experience dealing with foreign investors when this investment law was drafted. As the World Bank Country Assistance Strategy put it: 'Investment levels are low, and foreign investors are scarce. The Government is still establishing the institutional capacity to deal with the rapid changes in legislation that have been enacted to create a market economy' (World Bank, 1998, p. 1). The 1990s and 2000s were a period of political instability; the constitution was significantly reworked or rewritten nine times between 1993 and 2010 (Liebert \& Tiulegenov, 2013, p. 71). Internal World Bank documents describing the Kyrgyz government in the 1990s mention insufficient bureaucratic capacity consistently:

These delays are mainly attributable to the inexperience of the agencies involved and inadequate institutional capacity (World Bank, 1998 Annex B8 Attachment, p. 2).

The [Kyrgyz Republic], as a newly independent country, was struggling to formulate a reform program with limited policymaking capacity, weak and inappropriate institutions, and little exposure to international institutions or the ways of market economies (World Bank, 2000a, p. 4).

Poorer and smaller than its Central Asian neighbors, the Kyrgyz Republic joined the World Trade Organization (WTO) in 1998 and Kyrgyz governments in this era were generally eager to implement market reforms.

\section{Involvement of External Actors in Investment Policy Generally}

External actors, including donor agencies and IOs, were heavily involved in the Kyrgyz Republic when this law was drafted. The World Bank played a particularly important role. The only major foreign investment in the Kyrgyz Republic at the time was the investment made in the Kumtor 
gold mine, which was insured by the World Bank's insurance arm (World Bank, 1998, p. 17). The World Bank's International Finance Corporation also provided a US $\$ 30$ million loan for the mine (World Bank, 1998 Annex B8, p. 2). The Kumtor mine was run by a Canadian company, but the project was mediated by World Bank officials (World Bank, 1998 Private Sector Assessment, p. 6).

The World Bank and the American aid agency USAID were early providers of technical assistance for legal reform related to foreign investment (World Bank, 2000a, p. 12). By 1998, other donors had joined them in working on reforming the investment climate in the Kyrgyz Republic, including the International Monetary Fund, the European Bank for Reconstruction and Development, Germany, Japan, and Switzerland (World Bank, 1998, p. 18). Many donors provided technical assistance related to drafting legislation (World Bank, 2009, p. 18). Fifty-five percent of all bills under consideration in the spring of 1998 were formulated by IOs or other technical assistance providers, a figure that rises to $65 \%$ in economic policy (Cooley and Ron, 2002, p. 19).

The Kyrgyz Republic's first investment law, passed in 1997, was drafted with considerable World Bank and USAID support. The enactment of this 1997 law was listed as a 'main achievement' in the World Bank report on a loan to the Kyrgyz Republic (World Bank, 1998 Annex B1, p. 4). This 1997 law does not include arbitration access.

\section{The FIAS Project}

The first formal FIAS mission on domestic law reform to the Kyrgyz Republic was undertaken in 1998. The FIAS project was initiated as part of the wider World Bank country assistance strategy for the Kyrgyz Republic, which included an adjustment credit 'to improve the environment for private sector investment', and noted that FIAS, along with two other World 
Bank agencies, would 'be active participants in formulating the policies' for this improvement (World Bank, 1998, p. ii). The formal invitation to FIAS advisers came from the State Committee on Foreign Investments (GOSKOMINVEST), which itself was created via technical assistance under the 1993-1996 World Bank loan (World Bank, 2000a, p. 4).

In 1998, FIAS officials undertook diagnostic exercises and consultations. The working group within GOSKOMINVEST that would be responsible for drafting the law was created then.31 To evaluate our alternative explanations, we probed if other actors advocated for arbitration in the law, but did not find evidence of that. Mining companies were the main foreign investors interested in the Kyrgyz Republic, and even World Bank documents note that these companies sought to negotiate contracts with the government instead of relying on the domestic law, for instance: 'many mining investors will still seek to negotiate separate investment agreements with the authorities, which can provide for better investment terms' (World Bank, 1998, p. 6).

The investment law was drafted and considered in parallel to a Law on Arbitration Courts, which is 'mostly based on the UNCITRAL Model Law' (Korobeinikov, 2017, p. 275). This demonstrates that an international template coming into the Kyrgyz Republic and being translated into domestic law was an established practice. Kyrgyz actors pointed out that international templates are not copied and pasted wholesale, and other models, such as Russian and Kazakh laws, are also often looked at, as well as older laws.32 Similarly, Kyrgyz actors note that foreign advisers 'don't overpower' locals and that there is often contestation in working groups, but it does not take the form of 'foreign institutions pressuring and locals resisting', rather that the splits usually depend on whose ministries or jobs will be affected by the new 
law.33 Yet this same individual noted that sometimes there are not splits within the Kyrgyz government. When asked to describe who would be for or against including arbitration in the law, they answered: 'I think the government did not deliberate much in 2003, we didn't have any cases. If we had, all of the Kyrgyz government would have been against it.' 34

By 2000, there was an initial draft of the law, which FIAS officials reviewed (World Bank, 2000b). In 2001, FIAS officials undertook a third review, and provided comments on the latest draft (World Bank, 2001). The comments that FIAS provides are confidential, but based on the publicly available Handbook.

\section{Pending World Bank Loan}

The investment law passed in March 2003, just before the approval of a large concessional loan from the World Bank. The loan was approved May 15, 2003 and the first tranche of this loan was released July 31, after being delayed because the Kyrgyz Republic had not yet met the policy conditions for disbursement (World Bank, 2009, p. 4). This timing, and Kyrgyz officials' preparing progress reports on their implementation of 'legislative action plans' and timetables 'for further legal reform actions, satisfactory to [the World Bank]' at this time, suggest a role for structural power or coercion (World Bank, 2000a Annex D, p. 36). The World Bank was undoubtedly in a commanding position, but there was no formal conditionality: a new investment law was not one of the conditions the Kyrgyz government had to meet for the loan to be released (World Bank, 2009, p. 5). In contrast, passing other laws based on international templates were formal conditions for the loan, for instance, a procurement law based on an UNCITRAL model law (World Bank, 2009, p. 5). Since passing an investment law was not a formal condition for 
the loan, our alternative explanation about coercion does not hold.

\section{Legislative Approval and Subsequent Events}

In the late 1990s, World Bank officials started providing training for Kyrgyz parliamentarians about how to prepare and implement legislation related to World Bank work (World Bank, 1998, p. 16). Training for parliamentarians was seen as an important way of addressing a widespread perception that 'neither the citizenry at large nor the Parliament in particular have been well informed about, much less feel themselves to be stakeholders in, the reform process' (World Bank, 2000a, p. 25). Procedurally, the Parliament (Jogorku Kenesh) must review draft laws multiple times, yet often falls short of robust scrutiny: 'by law they have to review, scrutinize and question the drafters. But often they do not, either because they are not interested or because they do not have enough time or capacity to do the full research'.35

Yet the Parliament was capable of unpicking or frustrating certain aspects of laws drafted with heavy World Bank involvement, when it sought to do so (Cooley and Ron 2002, p. 21-36). An internal World Bank document reports: 'The Parliament, which has passed an impressive body of market-oriented legislation, has on occasion undone key provisions through subsequent amendments' (World Bank, 1998, p. 4). That did not happen with the investment law, which was adopted in March 2003, and is often seen as a package with the Law on Arbitration Courts and the creation of the International Arbitration Court in the Kyrgyz Republic.

This case study illustrates our mechanism: FIAS technical assistance introduced a domestic law template with consent to arbitration. While there was no coercion from the World Bank, there was strong external involvement and little domestic deliberation. Since 2003, the

35 Kyrgyz official, Interview B, 2019. 
Kyrgyz Republic has been a respondent in 14 known arbitration cases, and in at least five of these cases, the jurisdictional claim was based on the 2003 investment law.36

\section{Conclusion}

In this paper, we examine IO analytic institutions and the asymmetric diffusion of best practice. We focus on including arbitration in domestic law, a policy defined as best practice by the World Bank but only recommended to a subset of states. We find that FIAS technical assistance is an exceptionally strong predictor of arbitration clauses in domestic investment laws. We are relatively confident that there is a causal link between receiving FIAS technical assistance and consenting to arbitration in domestic investment laws. Our interviewees alleviated our endogeneity concerns and the strong relationship we found between FIAS involvement and arbitration clauses in domestic laws is robust to controlling for wider IO or donor community involvement and lending. Our placebo tests and the specificity of our findings increases our confidence in a causal link.

We see implications from these findings for scholars and for practitioners. Our interviews and findings suggest the drafting of these domestic laws is a strategic context permeated by international actors. Future research could probe how other types of international actors, including aid agencies, business associations, and foreign law firms, are involved in domestic investment law-making processes. In particular, analyzing technical assistance provided by national aid agencies, typically under the heading of commercial law reform, may help to explain investment laws with arbitration in countries that did not receive FIAS advice. Even in the cases we do not explain here, we think it is likely that governments were prompted by external actors

36 Sistem v. Kyrgyzstan (2006); Nadel. v. Kyrgyzstan (2012); Levitis v. Kyrgyzstan (2012); Stans Energy v. Kyrgyzstan (II) (2015); and, Consolidated Exploration v. Kyrgyzstan (2013). 
to provide arbitration consent. Of all the available policies to encourage investment, arbitration in domestic law is an odd, little-known choice, unlikely to appeal within governments (as the interviewee quoted earlier noted, 'If we had [deliberated it], all of the Kyrgyz government would have been against it').

Our findings also have implications for practitioners. Domestic investment laws have not featured much in discussions about the backlash against investor-state arbitration, or how it might be reformed. Yet, after arbitration cases, several governments have rewritten their domestic investment laws to remove access to arbitration, including El Salvador and Egypt, as discussed in Appendix A. The increasing salience of investor-state arbitration means that recommendations to provide consent in domestic laws may trigger internal and external contestation. For instance, after Myanmar received advice from FIAS, drafts of a new law that included consent to arbitration were circulated for consultation; at that point, the consent provisions were contested, and eventually removed.37 Despite these examples, there is still a disconnect: recommending arbitration in domestic investment laws is out of step with current government discussions in multilateral fora, which focus on replacing investor-state arbitration or undertaking systemic reform. FIAS could revisit its guidance on inserting arbitration into domestic laws in light of growing evidence about the costs and benefits of investor-state arbitration.

Our findings also have an implication for arbitrators who interpret these laws. Currently, if a domestic investment law is unclear, then 'arbitral practice, if anything, appears to incline toward a liberal interpretation' (Caron, 2010, p. 673). A liberal interpretation asserts that a government intended to give foreign investors consent to arbitration, if there is unclear language.

${ }_{37}$ We are grateful to Jonathan Bonnitcha for discussing this with us. 
Some arbitrators, like Caron, argue that a liberal interpretation is appropriate because of assumptions they make about 'the circumstances of a reasoned, debated, public law' (Caron, 2010, p. 674). In this paper, we find that many domestic investment laws are drafted with heavy external input and relatively little deliberation, which suggests these assumptions need to be revisited. 


\section{References}

Allee, T., \& Peinhardt, C. (2014). Evaluating three explanations for the design of bilateral investment treaties. World Politics, 66(1), 47-87.

Barnett, M., \& Finnemore, M. (2004). Rules for the world: International organizations in global politics. Ithaca: Cornell University Press.

Berge, T. L., \& Berger, A. (2019). Does investor-state dispute settlement lead to regulatory chill of domestic environmental regulation? The role of respondent state capacity. Paper presented at the 2019 Political Economy of International Organizations Annual Conference.

Best, J. (2017). The rise of measurement-driven governance: The case of international development. Global Governance, 23(2), 163-181.

Betz, T., \& Pond, A. (2019). Foreign financing and the international sources of property rights. World Politics, 71(3), 1-39.

Block-Lieb, S., \& Halliday, T. C. (2017). Global lawmakers: International organizations in the crafting of world markets. Cambridge: Cambridge University Press.

Bonnitcha, J. (2017). Investment laws of ASEAN countries: A comparative review. Report written for the International Institute for Sustainable Development (IISD).

Bonnitcha, J., Poulsen, L. N. S., \& Waibel, M. (2017). The political economy of the investment treaty regime. Oxford: Oxford University Press.

Box-Steffensmeier, J. M., \& Jones, B. S. (2004). Event history modelling: A guide for social scientists. Cambridge: Cambridge University Press.

Broome, A., Homolar, A., \& Kranke, M. (2018). Bad science: International organizations and the indirect power of global benchmarking. European Journal of International Relations, 24(3), 514-539.

Broome, A., \& Quirk, J. (2015). Governing the world at a distance: The practice of global benchmarking. Review of International Studies, 41, 819-841.

Broome, A., \& Seabrooke, L. (2007). Seeing like the IMF: Institutional change in small open economies. Review of International Political Economy, 14(4), 576-601.

Broome, A., \& Seabrooke, L. (2012). Seeing like an international organisation. New Political Economy, 17(1), 1-16. 
Broome, A., \& Seabrooke, L. (2015). Shaping policy curves: Cognitive authority in transnational capacity building. Public Administration, 93(4), 956-972.

Caron, D. (2010). 'The interpretation of national foreign investment laws as unilateral acts under international law'. In M. Arsanjani, J. Cogan, R. Sloane, \& S. Wiessner (Eds.), Looking to the future: Essays on international law in honor of W. Michael Reisman. Leiden: Martinus Nijhoff Publishers, 649-674.

Chorev, N. (2013). Restructuring neoliberalism at the World Health Organization. Review of International Political Economy, 20(3), 627-666.

Clegg, L. (2010). Our dream is a world full of poverty indicators: The US, the World Bank, and the power of numbers. New Political Economy, 15(4), 473-492.

Cooley, A., \& Ron, J. (2002) The NGO scramble: Organizational insecurity and the political economy of transnational action. International Security, 27(1), 5-39.

Cooley, A., \& Snyder, J. (Eds.) (2015). Ranking the world: Grading states as a tool of global governance. Cambridge, UK: Cambridge University Press.

Coppedge, M., Gerring, J., Knutsen, C. H., Lindberg, S. I., Skaaning, S-E., Teorell, J., Altman, D., Bernhard, M., Cornell, A., Fish, M. S., Gjerløw, H., Glynn, A., Hicken, A., Krusell, J., Lührmann, A., Marquardt, K. L., McMann, K., Mechkova, V., Olin, M., Paxton, P., Pemstein, D., Seim, B., Sigman, R., Staton, J., Sundström, A., Tzelgov, A., Uberti, L., Wang, Y-T., Wig, T., \& Ziblatt, D. (2018). 'V-Dem Codebook, v8', Varieties of Democracy (V-Dem) Project.

Davis, K., Fisher, A., Kingsbury, B., \& Merry, S. E. (Eds.) (2012). Governance by indicators: Global power through quantification and rankings. Oxford: Oxford University Press. Elkins, Z., Guzman, A. T., \& Simmons, B. A. (2006). Competing for capital: The diffusion of bilateral investment treaties, 1960-2000. International Organization, 60(4), 811-846.

Fatouros, A. A. (1962). Government guarantees to foreign investors. New York: Columbia University Press.

FIAS. (2006). FIAS, the facility for investment climate advisory services: 2006 annual report. Washington DC: World Bank.

FIAS. (2010). Investment law reform: A handbook for development practitioners. Washington DC: World Bank. 
FIAS. (2014). FIAS, the facility for investment climate advisory services: 2014 annual review. Washington DC: World Bank.

Finnemore, M. (1993). International organizations as teachers of norms: The United Nations Educational, Scientific, and Cultural Organization and science policy. International Organization, 47(4), 565-597.

Gertz, G. (2018). Commercial diplomacy and political risk. International Studies Quarterly, 62(1), 94-107.

Golub, J. (2008). 'Survival analysis'. In J. M. Box-Steffensmeier, H. E. Brady, \& D. Collier (Eds.), The Oxford handbook of political methodology. Oxford: Oxford University Press.

Graham, B., \& Tucker, A. T. (2019). The international political economy data resource. Review of International Organizations, 14(1), 149-161.

Guzman, A. T. (1998). Why LDCs sign treaties that hurt them: Explaining the popularity of bilateral investment treaties. Virginia Journal of International Law, 38, 639-688.

Gwynn, M. (2016). Power in the international investment framework. Basingstoke: Palgrave Macmillan.

Halliday, T. C., Block-Lieb, S., \& Carruthers, B. G. (2010) Rhetorical legitimation: Global scripts as strategic devices of international organizations. Socio-Economic Review, 8(1), 77-112.

Hepburn, J. (2018). Domestic investment statutes in international law. American Journal of International Law, 112(4), 658-706.

Hertz-Picciotto, I., \& Rockhill, B. (1997). Validity and efficiency of approximation methods for tied survival times in Cox regression. Biometrics, 53(3), 1151-1156.

Jacoby, W. (2001). Tutors and pupils: International organizations, Central European elites, and Western models. Governance, 14(2), 169-200.

Jandhyala, S., Henisz, W. J., \& Mansfield, E. D. (2011). Three waves of BITs: The global diffusion of foreign investment policy. Journal of Conflict Resolution, 55(6), 1047-1073.

Kelley, J., \& Simmons, B. (2015). Politics by number: Indicators as social pressure in international relations. American Journal of Political Science, 59(1), 55-70.

Kelley, J., \& Simmons, B. (2019). Introduction: The power of global performance indicators. International Organization, 73(3), 491-510. 
Kentikelenis, A. E., \& Seabrooke, L. (2017). The politics of world polity: Script-writing in international organizations. American Sociological Review, 82(5), 1065-1092.

Korobeinikov, A. (2017). Kyrgyzstan, in The Baker McKenzie international arbitration yearbook 2016-2017. London: Baker McKenzie.

Liebert, S., \& Tiulegenov, M. (2013). 'Public administration in Kyrgyzstan', in Public administration in post-communist countries: Former Soviet Union, Central and Eastern Europe, and Mongolia, edited by S. Liebert, S. Condrey, \& D. Goncharov. London: Routledge.

Marshall, M., Gurr, T. R., \& Jaggers, K. (2018). Polity IV Project. Political Regime Characteristics and Transitions, 1800-2017. Dataset Users' Manual. Center for Systemic Peace.

Maurer, N. (2013). The Empire Trap: The Rise and Fall of U.S. Intervention to Protect American Property Overseas, 1893-2013. Princeton: Princeton University Press.

Merry, S. E., Davis, K. E., \& Kingsbury, B. (Eds.) (2015). The quiet power of indicators: Measuring governance, corruption, and rule of law. Cambridge, UK: Cambridge University Press.

Park, S., \& Vetterlein, A. (2010). Owning development: Creating policy norms in the IMF and World Bank. Cambridge, UK: Cambridge University Press.

Parra, A. (1992). Principles Governing Foreign Investment, as Reflected in National Investment Codes. ICSID Review, 7(2), 428-452.

Parra, A. (1997). Provisions on the settlement of investment disputes in modern investment laws, bilateral investment treaties and multilateral instruments on investment. ICSID Review, 12(2), 287-364.

Parra, A. (2017). The History of ICSID. Second edition. Oxford: Oxford University Press.

Pelc, K. J. (2017). What explains the low success rate of investor-state disputes? International Organization, 71(3), 559-583.

Potestà, M. (2011). The interpretation of consent to ICSID arbitration contained in domestic investment laws. Arbitration International, 27(2), 149-170.

Poulsen, L. N. S. (2015). Bounded rationality and economic diplomacy: The politics of investment treaties in developing countries. Cambridge: Cambridge University Press. 
Poulsen, L. N. S., \& Aisbett, E. (2013). When the claim hits: Bilateral investment treaties and bounded rational learning. World Politics, 65(2), 273-313.

Scott, J. (1998). Seeing like a state: How certain schemes to improve the human condition have failed. New Haven: Yale University Press.

Seabrooke, L., \& Sending, O. J. (2019). Contracting development: Managerialism and consultants in intergovernmental organizations. Review of International Political Economy, 1-26.

Seawright, J., \& Gerring, J. (2008). Case selection techniques in case study research: A menu of qualitative and quantitative options. Political Research Quarterly, 61(2), 294-308.

Sharman, J. (2012). Seeing like the OECD on tax. New Political Economy, 17(1), 17-33.

Shihata, I. F. I. (1991). Promotion of foreign direct investment - A general account, with particular reference to the role of the World Bank. ICSID Review, 6(2), 484-509.

Shihata, I. F. I. (1993). Legal treatment of foreign investment: The World Bank Guidelines. London: Martinus Nijhoff.

Strang, D. (1991). Adding social structure to diffusion models: An event history framework. Sociological Methods \& Research, 19(3), 324-353.

St John, T. (2018). The rise of investor-state arbitration: Politics, law and unintended consequences. Oxford: Oxford University Press.

UNCTAD. (2016). Investment laws: A widespread tool for the promotion and regulation of foreign investment. UNCTAD Investment Policy Monitor, Special Issue, November.

Vetterlein, A. (2012). Seeing like the World Bank on poverty. New Political Economy, 17(1), $35-58$.

Wellhausen, R. (2015). The shield of nationality: When governments break contracts with foreign firms. Cambridge: Cambridge University Press.

World Bank. (1995). The World Bank and legal technical assistance: Initial lessons. Policy research working paper 1414. Washington, DC: World Bank Legal Department.

World Bank. (1998). Memorandum of the President of the International Bank for Reconstruction and Development, the International Development Association and the International Finance Corporation to the Executive Directors on a joint country assistance strategy of the World Bank Group for the Kyrgyz Republic. Washington DC: World Bank. 
World Bank. (2000a). Performance audit report: The Kyrgyz Republic Rehabilitation Credit (RC) and Privatization and Enterprise Sector Adjustment Credit (PESAC). Washington DC: World Bank Operations Evaluations Department.

World Bank. (2000b). Foreign Investment Advisory Service (FIAS) program bi-annual report for FY1999 and FY2000. Washington DC: World Bank.

World Bank. (2001). Foreign Investment Advisory Service - FIAS - program annual report for FY2001. Washington DC: World Bank.

World Bank. (2004). An evaluation of World Bank investment climate activities. Washington DC: World Bank Operations Evaluation Department.

World Bank. (2009). Implementation completion and results report on a IDA credit to the Kyrgyz Republic for a governance structural adjustment credit. Washington DC: World Bank Poverty Reduction and Economic Management Unit. 


\section{Appendix A. Coding of Domestic Investment Laws}

In this appendix, we elaborate how we coded our dependent variable, the dispute resolution clauses of domestic investment laws. The Appendix has five sections. First, it discusses our domestic law sources. Second, it addresses the issue of change over time. Third, it explains how we tackled ambiguous language and borderline cases. Fourth, it presents the list of laws that mention arbitration. Fifth, it presents the rationale behind the coding for each law coded as giving consent to arbitration.

\section{Sources}

We used two main sources to find the domestic investment laws. Our primary resource is UNCTAD Investment Policy Hub's repository of domestic investment laws.40 The UNCTAD repository only includes laws currently in force. We also consulted current and previous versions of ICSID's Investment Laws of the World volumes.41 These volumes have been published since 1973 and are updated at regular intervals: when a country updates its domestic law, the government should report the new law to the ICSID Secretariat, who then updates that country's entry in these volumes.

Once we had identified what we believed was the first mention or consent to arbitration, we then undertook secondary research to confirm our codings, using older IO publications, legal scholarship, arbitration awards, and contacting governments. In general we worked backwards from the investment law we had identified, trying to find any previous investment laws in that country, then checking if the previous laws mentioned or consented to arbitration.

We also used available tribunal decisions to code if provisions have been found to provide consent or not. In order to identify and access tribunal decisions on domestic law cases, we used: Investment Treaty Arbitration (ITA) Law,42 PluriCourts Investment Treaty Arbitration Database (PITAD), 43 and, when awards or other actual case documents were not available,

40 See: http://investmentpolicyhub.unctad.org/InvestmentLaws

${ }_{41}$ See: https://icsid.worldbank.org/en/Pages/resources/Investment-Laws-of-the-World.aspx)

42 See: https://www.italaw.com

43 See: https://pitad.org 
Investment Arbitration Reporter.44 We did not use UNCTAD since the 'Investment Disputes Settlement Navigator' only reports treaty-based arbitrations, not domestic law-based arbitrations.

We believe that we have the most comprehensive panel data yet compiled on the dispute resolution provisions of domestic investment laws, but despite our best attempts, it is possible that some previous investment laws are not captured here. Constructing uninterrupted records of domestic legislation across all non-OECD countries between 1986-2015 and then ascertaining how tribunals have interpreted their dispute resolution provisions is a complex, multi-lingual, time-intensive task. We have aimed to be frank about the challenges of conducting research in this field and to be transparent about what laws we code and what information we used to code them. While we acknowledge the possibility of missing laws or differing interpretations, we note that for most countries, we were able to construct an uninterrupted record of what laws were in force between 1986-2015. Therefore, we do not think the potential missingness meaningfully affects our analysis.

\section{How we addressed change over time}

A main challenge in constructing this indicator was addressing change over time. In this section, we discuss how we addressed the four issues related to change over time.

\section{Countries with domestic investment laws with arbitration in force before 1986}

Four countries pass consent prior to 1985 as per our content coding of dispute settlement procedures in domestic investment laws: Tunisia (1969), Egypt (1974), Sri Lanka (1978) and The Republic of the Congo (1982). These countries are excluded from our population.

\section{Countries that rewrote their laws to remove consent}

Several countries have passed laws that provide access to arbitration after 1986, then passed new laws that remove the consent. These countries exit the population on the day they pass the law that mentions (or consents) to arbitration. Their subsequent actions do not affect our results.

44 See: https://www.iareporter.com 
These countries include: El Salvador (consent 1999-2009), Guinea (consent 1987-2015), Jordan (consent 1995-2014), Kazahkstan (consent 1994-2003). Egypt and Tunisia also removed consent from their laws, but they consented before our time period begins.

\section{Countries that updated their laws and alter the dispute resolution clause}

For countries that pass multiple laws between 1986 and 2015, they exit on the day they pass the first law with a mention or with consent (depending on what is being measured). In some instances, countries first pass a law with explicit consent to arbitration, before passing a new law that moderates the degree of consent, and in some instances it goes the other way. An example of the former is Niger, who passed a law in 2001 that gave clear consent to arbitration, before passing a new law in 2014 where the consent is less clear. Niger still exits our sample in 2001. An example of the latter is Gambia, who passed a law in 2001 that did not give consent to arbitration, before passing a new law in 2010 that gives clear consent. Gambia thus exited our sample in 2010.

\section{Countries that passed investment laws after 2015}

Between 31 December 2015, the final day in our analysis, and June 2019, two countries passed investment laws that mentioned arbitration: Laos (2016) and Myanmar (2016). We exclude these laws from our analysis, even though available evidence suggests they fit our explanation.

\section{Summary of investment laws that we studied, but exclude from our population}

Before: Tunisia (1969), Egypt (1974), Sri Lanka (1978), and the Republic of Congo (1982).

After: Laos (2016), Myanmar (2016)

Not World Bank members: Democratic People Republic of Korea (1992), and Kosovo (2005). Interestingly, the laws of both DPRK and Kosovo mention arbitration, and Kosovo provides clear consent to ICSID. 


\section{How we addressed ambiguous language and borderline cases}

Coding domestic laws for direct access to arbitration is a detailed, legal task. There are several ways in which laws can mention arbitration without providing access to it. Laws that do provide access to arbitration do so in many different wordings and formulations. Potestà (2011) identifies a spectrum of ways in which laws make reference to ICSID jurisdiction. At one end of Potestà's spectrum are domestic laws that contain a straightforward, standing offer by the state to submit disputes to arbitration. This is the case when the piece of legislation uses formulations such as "the host state hereby consents" or "the consent of the host state is constituted by this article." 45 In the middle of the spectrum is legislation which does not provide access to arbitration explicitly, but still may be found to give consent to arbitration: this occurred when ICSID tribunals examined Georgia's and El Salvador's laws and found they contained consent to ICSID.46 On the other end of the spectrum are formulations which provide access to arbitration "as may be mutually agreed by the parties", which tribunals have found do not provide access to arbitration without consent expressed in another instrument.47

Since precedent does not operate formally in arbitration, it is up to each tribunal to interpret a law's wording and decide if it has jurisdiction. Tribunal decisions interpreting domestic laws have not always been consistent. Therefore, while it is possible to identify patterns and general principles, it is impossible to predict, definitively, how laws will be interpreted in the future.

In light of this uncertainty, we employ two codings: laws that mention international arbitration and laws that provide consent to arbitration, or more precisely, laws that we believe tribunals are likely to interpret as providing direct access to arbitration, based on previous tribunal decisions on jurisdiction and published legal interpretations.

${ }_{45}$ For instance, the domestic law of Albania, 1993. This provision was at issue in Tradex Hellas $v$ Albania.

46 Zhinvali Development Ltd v. Republic of Georgia, ICSID ARB/00/1, Award, 24 January 2003; Inceysa Valliosoletana, SL v Republic of El Salvador, ICSID ARB/03/26, Award, 2 August 2006.

${ }_{47}$ For instance, the tribunal in Biwater Gauff v Tanzania found that the Tanzania's Investment Act of 1997 does not provide access to arbitration. It says disputes with foreign investors may be submitted to arbitration "as may be mutually agreed by the parties." Biwater Gauff Ltd v United Republic of Tanzania, ICSID ARB/05/22, Award, 24 July 2008, para 329. 
The first coding, laws that mention arbitration, is straightforward. If international arbitration is mentioned in the law, it is coded as " 1 ." If international arbitration is not mentioned, it is coded as " 0 ." The advantages of this coding are that it is clear and replicable. The disadvantage is that this coding likely overreports the number of domestic laws that provide access to arbitration. As mentioned above, there are many ways that laws can mention arbitration without providing access to it. Some domestic laws refer to arbitration, but specify the parties have to agree to the specific arbitration. 48 Other domestic laws indicate that bilateral or multilateral treaties signed by the state may provide for arbitration, but do not themselves provide access to arbitration.49 Future arbitration tribunals, however, may come to different conclusions and find that such clauses do provide them with jurisdiction.

The second coding, laws that we believe would be interpreted by a tribunal as providing consent to arbitration, attempts to isolate what really matters: if a domestic law provides foreign investors with direct access to arbitration. While more meaningful, this coding is more open to challenge, since the phrasing of some clauses is unclear. Our approach is to acknowledge that it is impossible to have a definitive count of which clauses provide consent, but take all possible steps to ensure that we have an authoritative, well-founded count. Therefore, we have taken several steps to check the validity of this indicator.

The first check is inter-rater reliability; we were able to compare our coding against the coding of an international organization, UNCTAD. (Note: UNCTAD's coding has no legal force and is unlikely to be taken into account by a tribunal.) In 2015, we coded every domestic investment law in the ten volumes of the Investment Laws of the World (2014) series, collected and published by ICSID. Then, in 2017, UNCTAD released their database of domestic investment laws, which had not previously been available. We were then able to compare the two codings for the laws in both repositories: there was a high degree of agreement, with differences on three laws only, and each difference was one coding "unclear" and the other coding "consent." After this initial comparison, we then undertook more research to fill in laws missing from both repositories and searched for tribunal decisions. To generate the "mentions arbitration" list, we followed four steps:

48 As examples of this, Potestà 2011 mentions Estonia's law on Investments of 1991, Indonesia's law on investments of 2007, and Azerbaijan's law on investments of 1992.

49 As examples of this, Potestà mentions Algeria's law of 1993, Uzbekistan's law of 1998, Ethiopia's law of 1996, Guatemala's law of 1998, Kazakhstan's law of 2003. 
1. We began with 57 clauses listed on the UNCTAD Investment Policy Hub as "International Arbitration: Consent" in December 2017.50

2. Then we added laws that appear in the ICSID Foreign Investment Laws of the World but are not included in the UNCTAD data, and mention international arbitration.

3. Then we added laws that were discussed in cases, but did not appear in either repository.

4. Then we searched for earlier laws that mentioned arbitration.

Then, once had the list below of 74 laws that mention arbitration, we coded those 74 to see which provided consent and which did not. Here is the procedure we followed:

1. If a tribunal has found that a law provides jurisdiction, then we code it 'Consent.' If a tribunal has found that a law does not provide jurisdiction, then we code it as 'No consent.' We follow tribunal decisions, even if according to our coding rules below it would have been coded differently.

2. If no tribunal has interpreted a provision, we then relied heavily on legal scholarship, in particular Michele Potestà's article on consent in domestic investment laws.

3. If a tribunal had not interpreted a provision and it was not discussed in legal scholarship, then we kept our rules for interpretation constant:

a. When a clause specifies that the investor and state "must agree" to submit the dispute to arbitration, we code this as not providing consent. Examples of this are: Estonia's Investment Law of 1991, Indonesia's Investment Law of 2007, and Azerbaijan's Investment Law of 1992.

b. When a clause specifies that arbitration must be agreed in the original contract, or that a country has signed bilateral or multilateral treaties that may provide for arbitration (but do not themselves provide access to arbitration), we code this as

50 See: http://investmentpolicyhub.unctad.org/InvestmentLaws/B\#il-top. 
not providing consent. Examples of this are: Algeria's Investment Law of 1993, Uzbekistan's Investment Law of 1998, Ethiopia's Law of 1996, Guatemala’s Investment Law of 1998, and Kazakhstan's Investment Law of 2003.

4. There are six laws listed in the table as unclear followed by what we think a tribunal is likely to decide. Our reasoning for each is summarized here:

a. Belarus. Unclear, would likely be interpreted as providing consent: 'If disputes not referred to the exclusive competence of courts of the Republic of Belarus, arisen between an investor and the Republic of Belarus are not regulated under a pre-trial procedure through negotiations ... then such disputes may, at the option of the investor, be regulated also: in an arbitration court [ICSID or UNCITRAL].'

b. Lithuania. Unclear, would likely be interpreted as providing consent. Article 6 (2) suggests the parties need to agree on the venue, but Article 6.3 gives unambiguous access. 'In the case of investment disputes the foreign investor/investors shall have the right to apply directly to the ICSID.'

c. Mauritania. Unclear, would likely be interpreted as providing consent Dispute procedure is the choice of the parties ("au choix des parties"), but the three options listed as choices are all international arbitration.

d. Nicaragua. Unclear, likely to be interpreted as providing consent. Any dispute may or can be submitted to international arbitration in accordance with what is established by regulation ("podrá someterse a Arbitraje Internacional de acuerdo con lo que se disponga reglamentariamente").

e. Russian Federation. Unclear, likely to be interpreted as no consent. Expert opinion as well as Russian Supreme Court decision suggesting no consent. The relevant language is: disputes 'shall be resolved in compliance with international treaties of the Russian Federation and federal laws in the court or arbitration court or in an international arbitration court.'

f. Syrian Arab Republic. Ambiguous, but may be interpreted by a tribunal as 
providing consent. The provision is not specific and does not mention any international instruments, but does say that if the disputing parties cannot reach an amicable solution, "each of them shall have the right to take the case to one of the following: Arbitration..." 


\section{Laws that mention international arbitration}

\begin{tabular}{|l|l|l|}
\hline Country & Law Name & Year passed \\
\hline Afghanistan & Law on Domestic and Foreign Private Investment & 2005 \\
\hline Albania & Law on Foreign Investments of November 1993 & 1993 \\
\hline Algeria & Algérie Promotion de l'investissement & 1993 \\
\hline Azerbaijan & Law on the Protection of Foreign Investments & 1992 \\
\hline Belarus & Law of the Republic of Belarus on Investments & 2013 \\
\hline Benin & $\begin{array}{l}\text { Law 90-002 of May 9, 1990 relating to the Code } \\
\text { of Investments }\end{array}$ & 1990 \\
\hline Bolivia & Ley de Inversiones & 1990 \\
\hline Bosnia and Herzegovina & Law on the Policy of Foreign Direct Investment & 1998 \\
\hline Burkina Faso & Code des Investissements & 1995 \\
\hline Burundi & Investment Code & 2008 \\
\hline Cabo Verde & External Investment Code & 1993 \\
\hline Cambodia & Law on Investment & 1994 \\
\hline Cameroon & Investment Charter & 1990 \\
\hline Central African Republic & Charte Communautaire de 1'Investissement & 2001 \\
\hline Chad & Charte des Investissements & 2008 \\
\hline China & Law on Sino-foreign Cooperative Joint Ventures & 1988 \\
\hline Colombia & Decreto 2080 de 2000 y sus Modificaciones & 2000 \\
\hline Côte d'Ivoire & Code des Investissements & 1995 \\
\hline $\begin{array}{l}\text { Democratic Republic of the } \\
\text { Congo }\end{array}$ & Code des Investissements & 2002 \\
\hline Ecuador & Ley de Promoción y Garantía de Inversiones & 1997 \\
\hline El Salvador & Investment Law (Decree No. 732) & 1999 \\
\hline Fiji & Foreign Investment Act of Fiji (Amendments) & 2004 \\
\hline Gambia & Investment and Export Promotion Agency Act & 2010 \\
\hline Georgia & $\begin{array}{l}\text { Law on the Investment Activity Promotion and } \\
\text { Guarantees }\end{array}$ & 1996 \\
\hline Ghana & Ghana Investment Promotion Centre Act & 1994 \\
\hline Guinea & Code Des Investissements & 1987 \\
\hline Guyana & Investment Act 2004 & 2004 \\
\hline Honduras & $\begin{array}{l}\text { Decreto No 51-2011 Ley para la Promocion y } \\
\text { Proteccion de Inversiones }\end{array}$ & 2011 \\
\hline Indonesia & Law Concerning Investment & 2007 \\
\hline Iran & $\begin{array}{l}\text { Law on Encouragement and Protection of Foreign } \\
\text { Investment }\end{array}$ & 2002 \\
\hline Iraq & Investment Law & 2006 \\
\hline Jordan & The Investment Promotion Law of 1995 & 1995 \\
\hline Kazakhstan & Law on Investments & 1994 \\
\hline & & \\
\hline
\end{tabular}




\begin{tabular}{|c|c|c|}
\hline Kuwait & $\begin{array}{l}\text { Law Regarding the Promotion of Direct } \\
\text { Investment }\end{array}$ & 2013 \\
\hline Kyrgyz Republic & Law on Investments & 2003 \\
\hline Liberia & Investment Act of 2010 & 2010 \\
\hline Libya & Law on Investment Promotion & 2010 \\
\hline Lithuania & Law on Investment & 1999 \\
\hline Madagascar & Investment Law & 2008 \\
\hline Malawi & Investment Promotion Act & 1992 \\
\hline Mali & $\begin{array}{l}\text { Law No. 91-048/AN-RM of } 26 \text { February } 1991 \\
\text { Bearing on Investment Law }\end{array}$ & 1991 \\
\hline Mauritania & Code des Investissements & 2002 \\
\hline Moldova & Law on Investments in Entrepreneurial Activity & 2004 \\
\hline Mongolia & Law on Investment & 2013 \\
\hline Montenegro & Foreign Investment Law & 2011 \\
\hline Mozambique & Law on Investment & 1993 \\
\hline Namibia & Foreign Investment Act & 1990 \\
\hline Nepal & $\begin{array}{l}\text { Foreign Investment and Technology Transfer Act } \\
1992\end{array}$ & 1992 \\
\hline Nicaragua & Ley de Promoción de Inversiones Extranjeras & 2000 \\
\hline Niger & Code des investissements en Republique du Niger & 1989 \\
\hline Nigeria & Nigerian Investment Promotion Commission Act & 1995 \\
\hline Oman & Foreign Capital Investment Law & 1994 \\
\hline Papua New Guinea & Investment Promotion Act 1992 & 1992 \\
\hline Paraguay & Ley de Inversiones & 1992 \\
\hline Qatar & $\begin{array}{l}\text { Law on Organization of Foreign Capital in the } \\
\text { Economic Activity }\end{array}$ & 2000 \\
\hline Russian Federation & Law on Foreign Investments & 1999 \\
\hline Rwanda & $\begin{array}{l}\text { Law Relating to Investment Promotion And } \\
\text { Facilitation }\end{array}$ & 2015 \\
\hline Sierra Leone & The Investment Promotion Act, 2004 & 2004 \\
\hline Solomon Islands & Foreign Investment Act 2005 & 2005 \\
\hline Somalia & The Foreign Investment Law & 1987 \\
\hline South Sudan & The Investment Promotion Act, 2009 & 2009 \\
\hline Sudan & National Investment Encouragement Act 2013 & 2013 \\
\hline Syrian Arab Republic & Investment Promotion Law & 2007 \\
\hline Tajikistan & $\begin{array}{l}\text { The Law of the Republic of Tajikistan on } \\
\text { Investments }\end{array}$ & 2007 \\
\hline Tanzania & Tanzania Investment Act, 1997 & 1997 \\
\hline Timor-Leste & Foreign Investment Law & 2005 \\
\hline Togo & Code Des Investissements & 1989 \\
\hline Tonga & Foreign Investment Act 2002 & 2002 \\
\hline Turkey & Foreign Direct Investment Law & 2003 \\
\hline
\end{tabular}




\begin{tabular}{|l|l|l|}
\hline Uganda & Investment Code Act & 1991 \\
\hline Uzbekistan & $\begin{array}{l}\text { Law on Guarantees and Measures of Protection of } \\
\text { Foreign Investors' Rights }\end{array}$ & 1998 \\
\hline Venezuela & Ley de Promoción y Protección de Inversiones & 1999 \\
\hline Yemen & Investment Law & 2010 \\
\hline Zambia & Zambia Development Agency Act 2006 & 2006 \\
\hline
\end{tabular}


Laws that consent to international arbitration

\begin{tabular}{|l|l|l|l|l|}
\hline Country & Law Name & $\begin{array}{l}\text { Year } \\
\text { passed }\end{array}$ & Source & Coding \\
\hline Afghanistan & $\begin{array}{l}\text { Law on Domestic and Foreign Private } \\
\text { Investment }\end{array}$ & 2005 & UNCTAD & Consent \\
\hline
\end{tabular}

Note: UNCTAD and ICSID 2012-1 both have 2005 Afghanistan Private Investment Laws, but the two are different. Both are unofficial translations (although the ICSID version is a translation provided by the Embassy of Afghanistan in Washington DC.) The dispute resolution clauses are below - both provide consent.

UNCTAD version

Article 26. Disputes between foreign and domestic investors versus the Office of Investment and government officials may be directly resolved in an amicable manner by understanding and observing the rules of this legislation and documentation of the Enterprise, including whatever specialized contracts have been signed and agreed upon.

Should the disputes not be resolved in this manner, the parties shall settle their dispute according to the provisions of the Washington Arbitration Regulations of March 18, 1965 or in accordance with the United Nation's Judiciary Laws for International Commerce.

Article 27. The decision based on theses international agreements for dispute settlement and/or their rendered judgments shall be final and both parties are obliged to accept such a final decision.

ICSID 2012-1 Version

Article 30, (5). If a dispute arises pursuant to a contract or other agreement between a Foreign Investor or an Approved Enterprise with foreign ownership on one hand and an administration or organization of the State on the other hand with regard to a Foreign Investment (...) the parties shall endeavor to settle such dispute amicably by mutual discussions. Failing such amicable settlement, and unless the parties to such dispute otherwise agree, the parties shall submit such dispute to: The International Centre for Settlement of Investment Disputes (ICSID) for settlement, pursuant to the Convention on the Settlement of Investment Disputes between States and Nationals of Other States of March 18, 1965. 2. Arbitration in Accordance with UNCTIRAL Rules if ICSID rules preclude [the Foreign Investors from] arbitrating before ICSID. The Government, in such cases, consents to the submission of any such dispute to ICSID for settlement by arbitration in accordance with Article 25 (1) of the Convention.

\begin{tabular}{|l|l|l|l|l|}
\hline Albania & $\begin{array}{l}\text { Law on Foreign Investments of } \\
\text { November 1993 }\end{array}$ & 1993 & ICSID & Consent \\
\hline
\end{tabular}


Tradex Hellas $v$ Albania found that Albania had "unambiguously" consented to the jurisdiction of the Centre by way of that legislative provision (171-178).

Article 8. Settling of Disputes. If a disagreement with respect to a foreign investment between a foreign investor and the state administration of the Republic of Albania, which is not settled by agreement, then the foreign investor may apply to a court or arbitration tribunal competent in the Republic of Albania, in accordance with its compensation for expropriation or discrimination, or with transfers under Article 7 of this law, then the foreign investor may also apply to the International Center for the Resolution of Investment Disputes (the Center) established by the Convention for the resolution of investment disputes between states and citizens of other states approved in Washington on March 18, 1965.

\begin{tabular}{|l|l|l|l|l|}
\hline Algeria & Algérie Promotion de l'investissement & 1993 & Potestà & No consent \\
\hline
\end{tabular}

Potestà argues "Article 43 of Law No. 93-12 reminds of the fact of BITs or multilateral treaties which may provide for arbitration."

ICSID (2009-2 version) replaced this law with several ordinances related to investment from 2001-8. None provided consent.

\begin{tabular}{|l|l|l|l|l|}
\hline Azerbaijan & $\begin{array}{l}\text { Law on the Protection of Foreign } \\
\text { Investments }\end{array}$ & 1992 & UNCTAD & No consent \\
\hline
\end{tabular}

Note: ICSID (2004-1) has a different title for the law and lists it as 1995, but the clause wording is the same. Potestà confirms that this clause means a dispute can only be submitted if both the state and investor choose to do so. Baker and McKenzie "Doing Business in Azerbaijan" also finds no consent (page 165 here: https://www.bakermckenzie.com//media/files/insight/publications/2018/04/bkdbgazerbaijanapr18.pdf?la=en): "Foreign investors may rely on the provisions of the CCP and the law On Protection of Foreign Investments dated 15 January 1992 (the 'Foreign Investment Law') pursuant to which investment disputes may be resolved either by Azerbaijani courts or in accordance with the dispute resolution procedures agreed by the parties. This may include international arbitration, either in Azerbaijan or abroad."

Article 42. Settlement of disputes. Disputes or disagreements arising between foreign investors and enterprises with foreign investments and state bodies of the Azerbaijan Republic, enterprises, public organizations and other legal entities of the Azerbaijan Republic, disputes and disagreements between participants of the enterprise with foreign investments and such enterprise itself are to be settled in Law Courts of the Azerbaijan Republic or, on agreement between the Parties, in the Court of Arbitration, including those abroad. 


\begin{tabular}{|l|l|l|l|l|}
\hline Belarus & $\begin{array}{l}\text { Law of the Republic of Belarus on } \\
\text { Investments }\end{array}$ & 2013 & UNCTAD & $\begin{array}{l}\text { Unclear, } \\
\text { but likely to } \\
\text { be } \\
\text { interpreted } \\
\text { as } \\
\text { providing } \\
\text { consent }\end{array}$ \\
\hline
\end{tabular}

Note: ICSID (2004-1) has a 2001 investment code that does not provide consent.

Article 13. Settlement of disputes between an investor and the Republic of Belarus

Disputes between an investor and the Republic of Belarus arising in the carrying out of investments are settled under a pre-trial procedure through negotiations, unless otherwise established by the legislative acts of the Republic of Belarus.

Disputes between an investor and the Republic of Belarus not regulated under a pre-trial procedure through negotiations within three months from the day of receipt of a written proposal about the regulation thereof are settled through court proceedings in accordance with the legislation of the Republic of Belarus.

If disputes not referred to the exclusive competence of courts of the Republic of Belarus, arisen between an investor and the Republic of Belarus are not regulated under a pre-trial procedure through negotiations within three months from the day of receipt of a written proposal about the regulation thereof under a pre-trial procedure, then such disputes may, at the option of the investor, be regulated also:

in an arbitration court being established for settlement of each specific disputed according to the Arbitration Rules of the United Nations Commission on International Trade Law (UNCITRAL), unless the parties agree otherwise; at the International Centre for Settlement of Investment Disputes (ICSID) in the case if this foreign investor is citizen or legal person of a member state of the Convention on the Settlement of Investment Disputes between States and Nationals of Other States of March 18, 1965.

In the case if a treaty of the Republic of Belarus and/or a contract concluded between an investor and the Republic of Belarus establishes otherwise in relation to the settlement of disputes between the investor and the Republic of Belarus arising in the carrying out of investments, then provisions of this treaty of the Republic of Belarus and/or the contract concluded between the investor and the Republic of Belarus shall be applied. 


\begin{tabular}{|l|l|l|l|l|}
\hline Benin & $\begin{array}{l}\text { Law 90-002 of May 9, 1990 relating to } \\
\text { the Code of Investments }\end{array}$ & IC90 & Consent \\
\hline
\end{tabular}

Title V, Article 74. Note: the copy provided to ICSID is a strange translation, but clearly provides ad hoc arbitration or 'the right to apply to ICSID.'

\begin{tabular}{|l|l|l|l|l|}
\hline Bolivia & $\begin{array}{l}\text { Law on the Policy of Foreign Direct } \\
\text { Investment (Ley No. 1182) }\end{array}$ & 1990 & ICSID & No consent \\
\hline
\end{tabular}

Our interpretation is based on the phrase 'in conformity with the constitution' ('de conformidad a la Constitución Política del Estado') which we believe would likely lead a tribunal to decline jurisdiction.

Article 10. Los inversionistas nacionales y extranjeros podrán acordar someter sus diferencias a tribunales arbitrales, de conformidad a la Constitución Política del Estado y normas internacionales. Article 11. Los inversionistas nacionales y extranjeros podrán acogerse a los incentivos otorgados por el Gobierno Nacional.

\begin{tabular}{|l|l|l|l|l|}
\hline $\begin{array}{l}\text { Bosnia and } \\
\text { Herzegovina }\end{array}$ & $\begin{array}{l}\text { Law on the Policy of Foreign Direct } \\
\text { Investment }\end{array}$ & 1998 & UNCTAD & No consent \\
\hline
\end{tabular}

Article 17 Foreign investment disputes shall be settled by the relevant courts in Bosnia and Herzegovina, unless interested parties contract some other procedure for the settlement of disputes, including but not limited to domestic or international conciliation or arbitration.

\begin{tabular}{|l|l|l|l|l|}
\hline Burkina Faso & Code des Investissements & 1995 & UNCTAD & Consent \\
\hline
\end{tabular}

Chapitre III. Règlement des différends

Article 30

Le règlement des différends résultant de l'application des dispositions du présent Code aux entreprises agréées et la détermination de l'indemnité due par méconnaissance ou violation des obligations imposées, des engagements souscrits ou des garanties octroyés peut, indépendamment des voies de recours devant la juridiction administrative du Burkina Faso faire l'objet d'une procédure d'arbitrage.

Il est prévu deux procédures d'arbitrage:

1. La constitution d'un collège arbitral par: 
désignation d'un arbitre par chacune des parties;

désignation d'un tiers arbitre par les deux premiers arbitres.

La désignation du second ou du tiers arbitre sera faite à l'initiative de la partie la plus diligente par la Cour Suprême du Burkina Faso dans l'un des cas suivants:

l'une des deux parties n'aurait pas désigné son arbitre dans les 60 jours suivant la notification par l'autre partie de son arbitre désigné;

les deux arbitres ne se seraient pas mis d'accord dans les 30 jours suivant la désignation du second arbitre sur le choix du tiers arbitre.

Les arbitres établiront leur procédure, ils statueront ex æquo et bobo, la sanction arbitrale sera définitivement exécutoire sans procédure d'exequatur.

2. Le recours au Centre International pour le règlement des Différends Relatifs aux Investissements (CIRDI).

Lorsque les intérêts étrangers sont en cause, il existe en outre deux voies de recours: recours au CIRDI (Centre International pour le règlement des Différends Relatifs aux Investissements) créé par la Banque Internationale pour la Reconstruction et le Développement par la Convention de 1965 ou recours à la Cour Permanente d'Arbitrage de la Hayes.

La demande d'arbitrage, à l'initiative de l'une des deux parties suspend automatiquement toute procédure contentieuse qui aurait été engagée auparavant.

\begin{tabular}{|l|l|l|l|l|}
\hline Burundi & Investment Code & 2008 & UNCTAD & Consent \\
\hline
\end{tabular}

Title IV. Settlement of disputes

Article 17 Disputes resulting from the application of the present investment code between the Government and the investor, which are not settled amicably, shall be settled in accordance with the laws and regulations in force in Burundi. Disputes can be settled, according to the choice of the investor, by internal institutional arbitration or international arbitration.

When the investor takes recourse to international arbitration, he will do so in accordance with arbitration rules of the International Centre for the Settlement of Investment Disputes as applicable at the time of execution of the investment which gave rise to the dispute.

\begin{tabular}{|l|l|l|l|l|}
\hline Cabo Verde & External Investment Code & 1993 & UNCTAD & Consent \\
\hline
\end{tabular}


Note: the law does not refer to the New York or ICSID Conventions for enforcement and says the arbitration will take place in Cabo Verde.

Article 17. Conciliation and Arbitration

Conflicts between the State and the foreign investor regarding foreign investments, will be solved by means of conciliation and arbitration, according to the present article, if other methods have not been established differently in international agreements signed by the Government of Cabo Verde or defined by common agreement by the parties.

The arbitration procedure is initiated by written notice from one party to the other, stating:

The notified party must respond in writing, within 30 days, referring expressly to all points listed in number 2 above. The arbitration will be performed by a single arbitrator, except when the parties agree upon the use of an arbitrage commission to be established non later than 45 days from the date of the written notice established in number 2.The single arbitrator will be appointed by joint agreement of both parties. They may choose to request his/her appointment by the Superior Court or, if the foreign investor is not Capeverdean, by an international arbitration entity agreed upon.

If, within 90 days of the written notice referred to in the previous number 2, there is no agreement on the process of nomination of a single arbitrator, any of the parties may request his/her nomination by the Paris headquarters of the International Chamber of Commerce. When the investor is a Capeverdean, the request is submitted to the Superior Court.The single arbitrator or the president of the commission designated by the Paris International Chamber of Commerce, as established previously, can not be of the same nationality of none of the involved parties.

The following applies to the resolution of conflicts: The arbitration will take place in Cabo Verde, if another location is not agreed upon by the parties. The arbitration language will be Portuguese, if the parties do not disagree on the matter. The decision of the arbitration is final and not subject to appeal.

\begin{tabular}{|l|l|l|l|l|}
\hline Cambodia & Law on Investment & 1994 & UNCTAD & No consent \\
\hline
\end{tabular}

Note: arbitration in or outside Cambodia "as agreed by both parties."

Article 20

Except for land-related disputes, any dispute relating to a QIP concerning its right and obligations set forth in the law shall be settled amicably as far as possible through consultation between the Council for the Development of Cambodia, the investors and any other party involved in the dispute.

If the parties failed to reach an amicable settlement within two months from the date of the first written request to enter such consultations, the dispute shall be brought by either party for:

Conciliation before the Council which shall provide its opinion, or Arbitration in or outside of Cambodia as agreed by both parties, or Trial by the tribunals of the Kingdom of Cambodia. 


\begin{tabular}{|l|l|l|l|l|}
\hline Cameroon & $\begin{array}{l}\text { Ordinance Law No. 90/7 of 8 Nov., } \\
1990\end{array}$ & 1990 & Article & Consent \\
\hline
\end{tabular}

The 1990 Code provided access to arbitration at the ICC or at ICSID, in article 45, according to: KofeleKale, Ndiva. (1991). 'Investment Codes as Instruments of Economic Policy: A Cameroon Case Study.' The International Lawyer 25 (4): 821-858.

'Article 45 reserves, to the foreign investor operating in Cameroon, the right to have any disputes pertaining to the validity and interpretation of the investment agreement resolved through arbitration or conciliation under the rules of the International Chamber of Commerce (ICC) or the International Centre for the Settlement of Investment Disputes (ICSID)' (Kofele-Kale, 1991: 837).

It is no publicly known if this 1990 law or the later 2002 law was used as the basis for the claim in Lafarge v Republic of Cameroon (ARB/02/4). In any case, this claim was discontinued 13 June 2003.

\begin{tabular}{|l|l|l|l|l|}
\hline $\begin{array}{l}\text { Central } \\
\text { African } \\
\text { Republic }\end{array}$ & $\begin{array}{l}\text { Charte Communautaire de } \\
\text { 1'Investissement }\end{array}$ & 2001 & UNCTAD & No consent \\
\hline
\end{tabular}

Note: Article 23 says the recourse to ICSID jurisdiction or the Additional Facility must be expressively set out in the license/approval (that the foreign investor got when initiating the investment).

Art 22. Tout différent opposant un ou plusieurs investisseurs à l'Etat centrafricain concernant l'application de la charte est réglé conformément à une procédure d'arbitrage et de conciliation découlant: (...) oit de la Convention du 10 mars 1965 pour le règlement des différends relatifs aux investissements entre l'Etat et les ressortissants d'autres Etats, établie sous l'égide de la Banque Interntionale pour la Reconstruction et le Développement (BIRD) et ratifiée par la République Centrafricaine le 23 février 1966; soit, si la personne physique ou morale concernée ne remplit pas les conditions de nationalité stipulées à l'article 25 de la Convention susvisée, conformément aux dispositions des règlements du mécanisme supplémentaire approuvées par le Conseil d'Administration du CIRDI. Article 23. Le recours aux juridictions du CIRDI ou au mécanisme supplémentaire tels qu'énoncés ci-dessus doit être expressément précisé dans les agréements.

Article 23

Le recours aux juridictions du CIRDI ou au mécanisme supplémentaire tels qu'énoncés ci-dessus doit être expressément précisé dans les agréments.

\begin{tabular}{|l|l|l|l|l|}
\hline Chad & Charte des Investissements & 2008 & UNCTAD & No consent \\
\hline
\end{tabular}


Article 8.

L'Etat veille à la promotion de la sécurité juridique et judiciaire et au renforcement de l'Etat de droit à travers les dispositions suivantes:

créer les conditions juridiques de base nécessaires pour attirer les investissements privés et renforcer les droits des investisseurs;

adhérer aux dispositions internationales de garantie et de protection des investissements et respecter les accords bilatéraux et multilatéraux y relatifs notamment ceux de l'Agence Multilatérale de Garantie des Investissements (AMGI), du Centre International pour le Règlement des Différends relatifs aux Investissements (CIRDI); garantir l'application des procédures et arrêts de la Cour Communautaire de Justice de la CEMAC et de la Cour Commune de Justice et d'Arbitrage (CCJA) de l'Organisation pour l'Harmonisation en Afrique du Droit des Affaires (OHADA); renforcer les capacités des magistrats dans le traitement des affaires commerciales; veiller à l'exécution diligente des décisions de justice et d'arbitrage.

\begin{tabular}{|l|l|l|l|l|}
\hline China & $\begin{array}{l}\text { Law on Sino-foreign Cooperative Joint } \\
\text { Ventures }\end{array}$ & 1988 & ICSID & No consent \\
\hline
\end{tabular}

Note: UNCTAD has two laws, including the Law on Wholly Foreign-Owned Enterprises (1986) that does not mention arbitration or dispute settlement. In this law, arbitration is mentioned, but must be included in the initial contract or agreed separately.

Article 25 If a dispute arises between Chinese and foreign partners over the implementation of a cooperative enterprise contract, the matter shall be resolved through consultation or mediation. If the Chinese and foreign partners are unwilling to use consultation or mediation to resolve the dispute or if consultation or mediation fail to produce a result, the matter may be submitted to a Chinese arbitral body or another arbitral body for arbitration in accordance with the provisions on arbitration in the cooperative enterprise contract or an arbitral agreement concluded in writing after the dispute has arisen.

If the Chinese and foreign partners have not included provisions on arbitration in the co-operative enterprise contract and fail to conclude a written arbitral agreement after a dispute has arisen, a suit may be filed in a Chinese court.

\begin{tabular}{|l|l|l|l|l|}
\hline Colombia & $\begin{array}{l}\text { Decreto } 2080 \text { de } 2000 \text { y sus } \\
\text { Modificaciones }\end{array}$ & 2000 & UNCTAD & No consent \\
\hline
\end{tabular}

Note: disputes will be resolved in Colombian courts "except as provided for in international treaties."

Artículo 14. Ley y jurisdicción aplicables 
Salvo lo dispuesto en los tratados o convenios internacionales vigentes, en la solución de controversias o conflictos derivados de la aplicación del régimen de las inversiones de capital del exterior, se aplicará lo dispuesto en la legislación colombiana.

Con la misma salvedad contemplada en el inciso anterior y sin perjuicio de las acciones que puedan instaurarse ante jurisdicciones extranjeras, todo lo atinente a las inversiones de capital del exterior, también estará sometido a la jurisdicción de los tribunales y normas arbitrales colombianas, salvo que las partes hayan pactado el arbitraje internacional.

\begin{tabular}{|l|l|l|l|l|}
\hline Côte d'Ivoire & Code des Investissements & 1995 & ICSID & Consent \\
\hline
\end{tabular}

Potestà calls this unambiguous consent (the 1995 and 2012 versions of the law are identical). The last line says that "the consent of the parties to the jurisdiction of ICSID or the additional mechanism, as the case may be, required by the instruments governing them, is hereby established for the Republic of Côte d'Ivoire, and is expressed expressly in the application for approval for the person concerned."

\section{Law at UNCTAD:}

Article 20

L'Etat garantit aux investisseurs, le droit à un procès équitable pour tout litige né dans le cadre de l'application des dispositions du présent Code.

Tout différend ou litige entre les personnes physiques ou morales étrangères et la République de Côte d'Ivoire, relatif à l'application du présent Code, à défaut d'un règlement amiable, est réglé par les juridictions ivoiriennes ou par un tribunal arbitral. Les compétences du tribunal arbitral sont déterminées dans les conditions ci-après:

des Accords et Traités relatifs à la protection des investissements sont conclus entre la République de Côte d'Ivoire et l'Etat dont la personne physique ou morale étrangère concernée est ressortissante;

une procédure de conciliation et d'arbitrage dont les parties sont convenues est définie;

la Convention du 18 mars 1965 pour le règlement des différends relatifs aux investissements entre Etats et ressortissants d'autres Etats, établie sous l'égide de la Banque Internationale pour la Reconstruction et le Développement et ratifiée par la République de Côte d'Ivoire en vertu du décret n ${ }^{\circ}$ 65-238 du 26 juin 1965, est applicable;

la personne concernée ne remplit pas les conditions de nationalité stipulée à l'article 25 de la convention susvisée, conformément aux dispositions des règlements du mécanisme supplémentaire, approuvé par le Conseil d'Administration du Centre International pour le Règlement des Différends relatifs aux Investissements, en abrégé CIRDI. Le consentement des parties à la compétence du CIRDI ou du 
mécanisme supplémentaire, selon le cas, requis par les instruments les régissant, est constitué pour la République de Côte d'Ivoire par le présent article, et est exprimé expressément dans la demande d'agrément pour la personne concernée.

\begin{tabular}{|l|l|l|l|l|}
\hline $\begin{array}{l}\text { Democratic } \\
\text { Republic of } \\
\text { the Congo }\end{array}$ & Code des Investissements & 2002 & UNCTAD & Consent \\
\hline
\end{tabular}


This law was the basis of jurisdiction for Abou Lahoud and Bounafeh-Abou Lahoud v Democratic Republic of the Congo, ICSID Case No ARB/10/4, as well as International Quantum Resources Limited, Frontier SPRL et Compagnie Minière de Sakania SPRL v. République démocratique du Congo, ICSID Case No. ARB/10/21. Potestà also says this clause has unambiguous consent.

Tire IX. Du règlement des litiges

Article 37

Les litiges pouvant survenir à l'occasion de l'interprétation ou de l'application des dispositions de la présente loi ou de l'Arrêté Interministériel prévu au Titre III de la présente loi peuvent faire l'objet d'un arbitrage, selon la procédure prévue aux articles 159 à 174 du Code de Procédure Civile Congolais.

Article 38

Tout différend entre un investisseur et la République Démocratique du Congo relatif à:

un contrat ou accord d'investissement;

une autorisation d'investissement octroyée par l'autorité compétente, ou;

toute violation des droits de l'investisseur et / ou de l'investissement attribués ou crées par le Code des investissements ou par d'autres lois nationales ou par les Traités et Conventions Internationaux auxquels la République Démocratique du Congo a adhéré est réglé dans la mesure du possible, à l'amiable par voie de négociations.

Si les parties ne parviennent pas à un règlement à l'amiable de leur différend dans un délai de 3 mois à compter de la première notification écrite demandant l'engagement de telles négociations, le différend sera réglé, à la requête de la partie lésée, conformément à une procédure d'arbitrage découlant:

ode la Convention du 18 mars 1965 pour le règlement des différends relatifs aux investissements entre Etats et Ressortissants d'autres Etats, (Convention CIRDI), ratifiée par la République Démocratique du Congo le 29 avril 1970 ou

des dispositions des Règlements du Mécanisme supplémentaire, si l'investisseur ne remplit pas les conditions de nationalité stipulées à l'article 25 de la Convention CIRDI;

du Règlement d'arbitrage de la Chambre de Commerce Internationale de Paris. Le consentement des parties à la compétence du CIRDI ou du Mécanisme Supplémentaire, selon le cas, requis par les instruments les régissant, est constitué en ce qui concerne la République Démocratique du Congo par le présent article et en ce qui concerne l'investisseur par sa demande d'admission au régime de la présente loi ou ultérieurement par acte séparé. 
Si l'investisseur a effectué son investissement par l'intermédiaire d'une société de droit congolais qu'il contrôle, les parties conviennent qu'une telle société, aux fins de la Convention CIRDI, doit être considérée comme un ressortissant d'un autre Etat contractant.

\begin{tabular}{|l|l|l|l|l|}
\hline Ecuador & $\begin{array}{l}\text { Ley de Promoción y Garantía de } \\
\text { Inversiones }\end{array}$ & 1997 & UNCTAD & No consent \\
\hline
\end{tabular}

Article 31. El Ecuador respeta plenamente los Tratados y Convenios que en materia de Promoción y Protección de Inversiones, incluyendo los referidos a evitar la doble tributación, ha firmado y ratificado con otros países o en el marco de su participación en organismos internacionales.

Article 32. El Estado y los inversionistas extranjeros podrán someter las controversias que se suscitaren por la aplicación de esta Ley a Tribunales Arbitrales constituidos en virtud de Tratados Internacionales de los cuales sea parte el Ecuador o a los procedimientos específicamente acordados o estipulados en los convenios bilaterales o multilaterales firmados y ratificados por el País.

\begin{tabular}{|l|l|l|l|l|}
\hline El Salvador & Investment Law (Decree No. 732) & 1999 & Cases & Consent \\
\hline
\end{tabular}

Article 15 of El Salvador's investment law was the basis for jurisdiction in Pacific Rim v El Salvador. The tribunal in Inceysa v. El Salvador noted that the law provided consent: "The foregoing clearly indicates that the Salvadoran State, by Article 15 of the Investment Law, made to the foreign investors a unilateral offer of consent to submit, if the foreign investor so decides, to the jurisdiction of the Centre, to hear all' disputes referring to investments' arising between El Salvador and the investor in question. However, in the case at hand, as indicated in the previous paragraphs, Inceysa cannot enjoy the rights granted by said Investment Law because its'investment' does not meet the conditions of legality."

Pac Rim Cayman LLC v. The Republic of El Salvador, Memorial Objections on Jurisdiction (page 114). Article 15:

Should disputes or differences arise among local or foreign investors and the State, regarding the investments made by them in El Salvador, the parties may resort to the competent courts of justice, in accordance with legal proceedings.

In case of disputes arising between foreign investors and the State, regarding their investments in El Salvador, the investors may refer the dispute to:

a) The International Centre for Settlement of Investment Disputes (ICSID), in order to settle the dispute by means of conciliation and arbitration, in accordance with the Convention on the Settlement of Investment Disputes between States and Nationals of other States (ICSID Convention) ....

\begin{tabular}{|l|l|l|l|l|}
\hline Fiji & $\begin{array}{l}\text { Foreign Investment Act of Fiji (2004 } \\
\text { Amendments) }\end{array}$ & 2004 & ICSID & No consent \\
\hline
\end{tabular}


Section 14 (3) A foreign investor has the same right as a national enterprise to recourse to the jurisdiction of courts or other tribunals of the Fiji Islands in respect of settlement of disputes.

(4) The court or tribunal may take into account the principles of the International Convention on Settlement of Investment Disputes when settling any disputes involving a foreign investor.

\begin{tabular}{|l|l|l|l|l|}
\hline Gambia & $\begin{array}{l}\text { Investment and Export Promotion } \\
\text { Agency Act }\end{array}$ & 2010 & UNCTAD & Consent \\
\hline
\end{tabular}

Note: ICSID (2008-1) has earlier law (from 2001), with a different clause that does not constitute consent.

Article 55. Dispute resolution

1) Where a dispute arises between investors or between an investor and the Government, the parties to the dispute shall settle their difference amicably through conciliation or mediation.

2) Where the parties fail to resolve the matter through conciliation or mediation they may resort to:

a. arbitration under the Alternative Dispute Resolution Act of The Gambia;

b. the international Centre for the Settlements of Investment Disputes; or

c. the provisions of any existing Bilateral Investment Treaty between The Gambia and the country the investor originates from.

\begin{tabular}{|l|l|l|l|l|}
\hline Georgia & $\begin{array}{l}\text { Law on the Investment Activity } \\
\text { Promotion and Guarantees }\end{array}$ & 1996 & UNCTAD & Consent \\
\hline
\end{tabular}

This law was the basis for Zhinvali Development Ltd v Republic of Georgia, in which the tribunal found it embodied state consent to ICSID.

Article 16. Procedure for dispute resolution

1) A dispute between a foreign investor and an enterprise registered in Georgia shall be subject to resolution under the agreement of the parties or in courts of Georgia.

2) A dispute between a foreign investor and a state agency shall unless the procedure for its resolution is not defined by way of their agreement, be subject to resolution in courts of Georgia or in the International Center for the Resolution Investment Disputes. Unless the dispute is considered in the 
International Center for the Resolution of Investment Disputes, a foreign investor shall be entitled to apply to any international arbitration body which has been set up by the Commission of the United Nations for International Trade Law - UNCITRAL to resolve the dispute in accordance with the rules established under the arbitration and international agreement.

3) Any award of the international arbitration bodies as indicated in paragraph 2 of this Article shall be final and not subject to appeal. Its observance shall be secured by the state.

\begin{tabular}{|l|l|l|l|l|}
\hline Ghana & $\begin{array}{l}\text { Ghana Investment Promotion Centre } \\
\text { Act }\end{array}$ & 1994 & ICSID & Consent \\
\hline
\end{tabular}

Article 29 (2) Any dispute between an investor and Government in respect of an enterprise to which this Act applies which is not amicably settled through mutual discussions may be submitted at the option of the aggrieved party to arbitration as follows----(a) in accordance with the rules of procedure for arbitration of UNCITRAL or (b) in the case of a foreign investor, within the framework of any bilateral or multilateral agreement on investment protection to which the Government and the country of which the investor is a national are parties (c) in accordance with any other national or international machinery for the settlement of investment dispute agreement to by the parties. (3) Where in respect of any dispute, there is disagreement between the investor and the Government as to the method of dispute settlement to be adopted, the choice of the investor shall prevail.

\begin{tabular}{|l|l|l|l|l|}
\hline Guinea & Code Des Investissements & 1987 & ICSID (1987-4) & Consent \\
\hline
\end{tabular}

Guinea's law was the basis for several claims:

Getma International and others v. Republic of Guinea [II], ICSID Case No. ARB/11/29

Société Civile Immobilière de Gaëta v. Republic of Guinea, ICSID Case No. ARB/12/36

BSG Resources Limited, BSG Resources (Guinea) Limited and BSG Resources (Guinea) SÀRL v. Republic of Guinea, ICSID Case No. ARB/14/22

The 1987 law was replaced in 2015 with a law that did not consent to arbitration. The text of the 1987 law is available here: https://www.italaw.com/sites/default/files/laws/ITA\%20LAW\%207039.pdf

Art.28.- 1) Les différends résultant de l'interpré tation ou de l'application du présent code, sont ré glés par les juridictions guinéennes compétentes conformément aux lois et règlements de la Répu blique.

2) Toutefois, les différends entre l'Etat Guinéen et les ressortissants étrangers, relatifs à l'application ou l'interprétation du présent code, sont, sauf ac cord contraire des parties en cause, définitivement réglés par arbitrage conduit : 
conformément aux dispositions de la conven tion du 18 mars 1985 pour le « Règlement des différends relatifs aux investissements entre Etats et ressortissants d'autres Etats » établie sous l'égide de la Banque Internationale pour la Reconstitution et le Développement, ratifiée par la République de Guinée le 4 novembre 1986, ou

si la personne ou l'entreprise concernée ne remplit pas les conditions de nationalité stipu lée à l'article 25 de ladite convention, confor mément aux dispositions des règlements du mécanisme supplémentaire approuvé le 27 sep tembre 1978, par le Conseil Administratif du Centre International pour le Règlement des Différends Relatifs aux Investissements (CIRDI).

\begin{tabular}{|l|l|l|l|l|}
\hline Guyana & Investment Act 2004 & 2004 & UNCTAD & Consent \\
\hline
\end{tabular}

Section 28. Dispute resolution

1) In the event of disputes among foreign investors within an investment enterprise, or among foreign investors and domestic investors, or among Guyanese investors, or between the investors and the Government with respect to an investment enterprise, the parties to the dispute shall first seek to settle their disputes through consultation or meditation in order to reach an amicable settlement.

2) If parties to the dispute fail to resolve the matter, they may;

a. submit their dispute to arbitration under the Arbitration Act;

b. invoke the jurisdiction of the competent courts in Guyana;

c. adopt such other procedure provided for in the articles of association or other constituent document of the investment enterprise; or

d. submit their dispute to the International Centre for the Settlement of Investment Disputes (ICSID) of which Guyana is a member.

\begin{tabular}{|l|l|l|l|l|}
\hline Honduras & $\begin{array}{l}\text { Decreto No 51-2011 Ley para la } \\
\text { Promocion y Proteccion de Inversiones }\end{array}$ & 2011 & ICSID (2012-2) & Consent \\
\hline
\end{tabular}

Articulo 25. Cuando no se logre un acuerdo a través de los medios de negociación y conciliación, los inversionistas extranjeros cuya nacionalidad corresponda a un Estado que hubiere suscrito y ratificado el CIADI o que se hubiere adherido al mismo con posterioridad, podrán recurrir a uno de los siguientes mecanismos de solución de conflictos: (1) Arbitraje Internacional ante el CIADI de conformidad consu Convenio Constitutivo y sus reglas internas; (2) Arbitraje nacional o internacional ante uno de los Centros de Conciliación y Arbitraje Nacional; y, (3) La Justicia Ordinaria. Articulo 26. En cuanto a los inversionistas de países que no son parte del Convenio Constitutivo del CIADI, en aquellos casos en que no se hubiese logrado un acuerdo a través de los medios de negociación y conciliación, podrán recurrir a 
uno de los siguientes mecanismos de solución de conflictos: (1) Arbitraje Internacional haciendo uso del mecanismo complementario del CIADI; 2 and 3 as above.

\begin{tabular}{|l|l|l|l|l|}
\hline Indonesia & Law Concerning Investment & 2007 & UNCTAD & No consent \\
\hline
\end{tabular}

Note: Potestà says that parties have to agree.

Chapter XV. Dispute settlement

Article 32

1) In the event of dispute in investment sector between Government and any investors, the two parties shall devote their entire effort to settle it with deliberation.

2) In the event that such settlement set forth in paragraph (1) above fails, such dispute shall be settled through arbitration or alternative settlement or court of justice in accordance with the rules of law.

3) In the event of dispute in investment sector between Government and any domestic investors, the two parties may settle it through arbitration based on agreement between them, and if such settlement through arbitration fails, such dispute shall be settled by court of justice.

4) In the event of dispute in investment sector between Government and any foreign investors, the two parties may settle it through international arbitration based on agreement between them.

\begin{tabular}{|l|l|l|l|l|}
\hline Iran & $\begin{array}{l}\text { Law on Encouragement and Protection } \\
\text { of Foreign Investment }\end{array}$ & 2002 & UNCTAD & No consent \\
\hline
\end{tabular}

Chapter VI. Settlement of disputes

Article 19

If disputes between the government and foreign investors over reciprocal obligations within the framework of investments stipulated in this law are not solved through negotiations, they should be referred to domestic courts unless under a contract, the government and the respective government of the foreign investor have already agreed upon another method for settlement of disputes.

\begin{tabular}{|l|l|l|l|l|}
\hline Iraq & Investment Law & 2006 & UNCTAD & No consent \\
\hline
\end{tabular}

Article 27 
Disputes arising between parties who are subject to the provisions of this law shall be subject to the Iraqi law unless otherwise agreed, contrary to the cases that are subject to the provisions of the Iraqi law exclusively or the jurisdiction of Iraqi courts.

1) Disputes arising from the work contract shall exclusively be subject to the provisions of the Iraqi law and the jurisdiction of Iraqi courts. Non-Iraqi laborer shall be exempted if the work contract stipulated otherwise.

2) If parties to a dispute are non-Iraqis and in disputes not arising from a crime, the opponents may agree on the law to be applied, the competent court or any other agreement to resolve their dispute.

3) If a dispute between the partners or between the owner of the project and others in a project subject to the provisions of this law resulted in the stoppage of work for a period exceeding three months, the Investment Commission may withdraw the license and ask the owners of the project to settle the dispute within a period not to exceed three months. If such period elapsed without settling the dispute between the partners or between the owner of the project and others, the commission may take legal measures to liquidate the project and notify the owner of the project or one of the partners of such action. The liquidation money shall be deposited in one of the banks after paying the dues of the State or any other dues after final judgment of their entitlement is rendered.

4) If one of the parties to a dispute is subject to the provisions of this law, they may, at the time of signing the agreement, agree on a mechanism to resolve disputes including arbitration pursuant to the Iraqi law or any other internationally recognized entity.

5) Disputes arising between the Commission or any governmental entity and any of those subject to the provisions of this law on matters not related to violations of one of the provisions of this law shall be subject to Iraqi law and courts on civil matters. As for commercial disputes, parties may resort to arbitration provided that such an arrangement is stipulated in the contract organizing the relationship between parties.

\begin{tabular}{|l|l|l|l|l|}
\hline Jordan & $\begin{array}{l}\text { The Investment Promotion Law of } \\
1995\end{array}$ & 1995 & ICSID & Consent \\
& & & $(2004-2)$
\end{tabular}

Article 33: Investment disputes between an Investor of Foreign Capital and Jordanian governmental agencies shall be settled amicably. If no amicable settlement can be reached within a period not exceeding six months, either party may resort to litigation or may refer the dispute to ICSID for settlement by conciliation or arbitration in accordance with the provision of the Agreement on the Settlement of Investment Disputes between states and Nationals of Other states, which has been signed by the Kingdom.

\begin{tabular}{|l|l|l|l|l|}
\hline Kazakhstan & Law on Investments & $1994-2003$ & Cases & Consent \\
\hline
\end{tabular}


The text of Article 27(3) of Kazakhstan's investment law makes a specific reference to "consent" when it states that once an investor chooses ICSID "the consent of the Republic of Kazakhstan 'shall be presumed to have been granted."

The Law of the Republic of Kazakhstan on Foreign Investments dated December 27, 1994 (entered into force on December 28, 1994) is cited in Rumeli Telekom AS and Telsim Mobil Telekomunikasyon Hizmetleri AS v. Republic of Kazakhstan, Award, 29 July 2008. In paras. 332-336, the tribunal "considers that it has jurisdiction on the basis of the Foreign Investment Law" (in addition to jurisdiction under a BIT). The case also notes that the relevant law was repealed as of January 8, 2003, and replaced.

The 2003 Law (on record with UNCITRAL does not provide consent. Potestà says that "Article 9 of the 2003 law merely reminds of the fact of BITs and multilateral treaties that may provide access."

Article 9. Disputes

1) Investment disputes can be resolved through negotiations, including with the involvement of experts, orin accordance with previously agreed by the parties dispute settlement procedures.

2) If you can not resolve investment disputes in accordance with the provisions of paragraph 1 of this article, the resolution of disputes shall be in accordance with international treaties and laws of the Republic of Kazakhstan in the courts of the Republic of Kazakhstan, as well as in international arbitrations, the parties specified in the agreement.

3) Disputes not related to investment, are settled in accordance with the laws of the Republic of Kazakhstan.

\begin{tabular}{|l|l|l|l|l|}
\hline Kuwait & $\begin{array}{l}\text { Law Regarding the Promotion of } \\
\text { Direct Investment }\end{array}$ & 2013 & UNCTAD & No consent \\
\hline
\end{tabular}

Article 26. Competent courts

The Kuwaiti courts are the ones solely competent to consider any disputes arising between investment projects and third parties, whoever they may be. The parties may also agree to refer such disputes to arbitration.

\begin{tabular}{|l|l|l|l|l|}
\hline $\begin{array}{l}\text { Kyrgyz } \\
\text { Republic }\end{array}$ & Law on Investments & 2003 & Cases & Consent \\
\hline
\end{tabular}

The Kyrgyz Republic law has been the basis for several claims, including: Stans Energy Corp and Kutisay Mining LLC v Kyrgyz Republic. The award from that arbitration, dated 25 January 2017, is not public, but it was summarized in the High Court of Justice case (CL-2017-000115), available here: 
https://www.italaw.com/sites/default/files/case-documents/italaw10537.pdf. High Court (of England and Wales) judge noted:

That Award was rendered in proceedings brought by Stans Energy Corp ("Stans") and Kutisay Mining LLC ("Kutisay") (together, "the Defendants") under Article 18(2) of Law No. 66 on investment in the Kyrgyz Republic of 27 March 2003 ("the 2003 Investment Law"), in which the Defendants seek compensation for the Republic's alleged violations of Kyrgyz and international law in respect of their investments in the Republic's mining sector. In that Award, the Tribunal dismissed each of the Republic's five objections to jurisdiction that the Tribunal had decided to resolve at that stage.

The Kyrgyz Republic applied to the High Court to challenge the substantive jurisdiction of the arbitral tribunal. After 47 pages debating if Article 18 (listed below) provides consent, the High Court decision finds the Tribunal has jurisdiction.

Note: in Petrobart Limited v. The Kyrgyz Republic, the investor's claim was based on an earlier law, but the tribunal declined jurisdiction. Award, issued in 2003:

https://www.italaw.com/sites/default/files/case-documents/ita0627.pdf)

Article 18. Settlement of investment disputes

1) Investment dispute shall be resovled [sic] in accordance with any applicable procedure agreed in advance between an investor and authorized state bodies of the Kyrgyz Republic that does not exclude the use of other means of legal defense by an investor in accordance with the legislation of the Kyrgyz Republic.

2) If such agreement is not reached the investment dispute between authorized state bodies of the Kyrgyz Republic and investor shall be resolved by conducting consultation between parties. If parties will not agree in 3 month period from the day of first written address for such consultation, the dispute shall be resolved by addressing to a court of the Kyrgyz Republic, unless one of the parties to a dispute between the foreign investor and the state body requests to consider the dispute in accordance with one of the following procedures:

a. by applying to the International Center for Settlement of Investment Disputes (ICSID) pursuant to the Convention on settlement of investment disputes between states and citizens of other states or the rules regulating the use of additional means for conduct of hearings by the Secretariat of the Center; or

b. by applying to arbitrage or an international temporary arbitral tribunal (commercial court) formed in accordance with the arbitration rules of UN Commission on international trade law.

3) In the event that an investment dispute is to be resolved through arbitrage as referred to in subpoints "a" and "b" of point 2 of this Article, the Kyrgyz Republic shall waive any claim for preliminary application of the internal administrative or judicial procedures prior to referral of the dispute to international arbitration. 
4) Any investment dispute between the foreign and domestic investors shall be considered by the judicial bodies of the Kyrgyz Republic unless the parties reach an agreement on any other dispute settlement procedure, including national and international arbitration.

5) Disputes between foreign investors and physical and legal entities of the Kyrgyz Republic may be resolved under agreement of parties by an arbitral tribunal of the Kyrgyz Republic as well as a foreign arbitral tribunal. In case if such agreement is not reached the disputes will be resolved in conformity with a procedure provided by the legislation of the Kyrgyz Republic.

\begin{tabular}{|l|l|l|l|l|}
\hline Liberia & Investment Act of 2010 & 2010 & UNCTAD & Consent \\
\hline
\end{tabular}

Note: ICSID (2011-2) lists this as the Investment Act of 2009, but the relevant text is identical.

Section 12. Dispute settlement Procedures

1) The courts of Liberia shall have jurisdiction over the resolution of business disputes. Parties to an investment dispute may however specify any arbitration or other dispute resolution procedure upon which they may agree.

2) Where a dispute arises between an investor and Government in respect of an enterprise, all efforts shall be made through mutual discussion to reach an amicable settlement.

3) Any dispute between an investor and Government in respect of an enterprise to which this Act applies which is not amicably settled through mutual discussions may be submitted at the option of the aggrieved party to arbitration as follows:

a. in accordance with any national or international machinery for the settlement of Investment dispute agreed to by the parties.

b. in the case of a foreign investor:

(i). in accordance with the rules and procedures for arbitration by the United Nations Commission on International Trade Law; or

(ii). within the framework of any bilateral or multilateral agreement on investment protection to which the Government and the country of which the investor is a national are parties;

\begin{tabular}{|l|l|l|l|l|}
\hline Libya & Law on Investment Promotion & 2010 & UNCTAD & No consent \\
\hline
\end{tabular}

Art. 24. Settlement of disputes

Any dispute that may arise between the foreign investor and the state, which may be attributed to the investor or due to procedures taken against him by the state, shall be forwarded to the appropriate courts 
of the state, unless if there are mutual agreements between the state and the investor's state or multilateral agreements to which the investor's state is a party thereof, including texts relating to reconciliation or arbitration or special agreement between the investor and the state stipulating arbitration as a condition.

\begin{tabular}{|l|l|l|l|l|}
\hline Lithuania & Law on Investment & 1999 & UNCTAD & $\begin{array}{l}\text { Unclear, } \\
\text { would } \\
\text { likely be } \\
\text { interpreted } \\
\text { as } \\
\text { providing } \\
\text { consent }\end{array}$ \\
\hline
\end{tabular}

Reason behind our coding: Article 6 (2) suggests the parties need to agree on the venue, but Article 6.3 gives unambiguous access. "In the case of investment disputes the foreign investor/investors shall have the right to apply directly to the ICSID."

Article 6. Guarantees of investors' rights

1) State and local authorities and officers shall have no right to interfere with the management and use as well as disposal of by the investors of the object of investment according to the procedure established by law. Damage inflicted upon the investor by unlawful actions of state or local authorities and their officers shall be compensated according to the procedure established by the laws of the Republic of Lithuania.

2) Disputes relating to infringement of the rights and lawful interests of the investor/investors shall be settled according to the procedure established by the laws of the Republic of Lithuania. Disputes between the foreign investor/investors and the Republic of Lithuania relating to infringement of their rights and lawful interests (investment disputes) shall be considered, upon agreement between the parties, by the courts of the Republic of Lithuania, international arbitration bodies or other institutions.

3) Investment disputes shall also be settled with due regard being had to the provisions of international treaties. In case of investment disputes the foreign investor/investors shall have the right to apply directly to the International Centre for Settlement of Investment Disputes.

\begin{tabular}{|l|l|l|l|l|}
\hline Madagascar & Investment Law & 2008 & UNCTAD & Consent \\
\hline
\end{tabular}

Note: There is an error in the text, it says "national investor" twice, where we believe it should say "foreign investor." While there is some ambiguity, the second half of the article seems likely to be interpreted as providing consent. 
Article 21. Dispute settlement

Disputes between national investors and the state relating to the interpretation or enforcement of this Act are submitted to the competent Malagasy jurisdictions unless the parties have agreed or agree to seek a different mean of dispute settlement.

Disputes between national investors and the state relating to the interpretation or enforcement of this Act are regulated in compliance with a legal or arbitration proceeding emerging from:

agreements and treaties, relating to the protection of investments, between the Malagasy state and the state the concerned investor is a member of; or failing this,

the international Convention for dispute settlement, ratified by law N66-011 dated 5th July 1966, relating to investments between States and nationals of other States.

However, if the foreign investor requests for the proceeding, he is free to choose to submit the dispute between him and the State to the Malagasy competent jurisdictions, in place of the arbitration proceeding above-mentioned.

\begin{tabular}{|l|l|l|l|l|}
\hline Malawi & Investment Promotion Act & 1992 & UNCTAD & No consent \\
\hline
\end{tabular}

Access to international arbitration

The Government acknowledges that investors must have an acceptable forum to resolve disputes that cannot be settled amicably. Parties to disputes may agree to pursue arbitration and to choose an appropriate forum, including international arbitration. The Government is a member of the International Centre for the Settlement of Investment Disputes (ICSID).

\begin{tabular}{|l|l|l|l|l|}
\hline Mali & $\begin{array}{l}\text { Law No. 91-048/AN-RM of 26 } \\
\text { February 1991 Bearing on Investment } \\
\text { Law }\end{array}$ & I991 & ICSID & Consent \\
\hline
\end{tabular}

Note: Potestà considers this provision to provide unambiguous consent.

Article 21. The consent [to ICSID arbitration] is made up of this article, as far as the government is concerned; it is expressly set out in the application for approval, as far as investors are concerned.

\begin{tabular}{|l|l|l|l|l|}
\hline Mauritania & Code des Investissements & 2002 & ICSID & $\begin{array}{l}\text { Unclear, } \\
\text { would } \\
\text { likely be } \\
\text { interpreted } \\
\text { as }\end{array}$ \\
\hline
\end{tabular}




\begin{tabular}{|l|l|l|l|l|}
\hline & & & & $\begin{array}{l}\text { providing } \\
\text { consent }\end{array}$ \\
\hline
\end{tabular}

Note: In the article below, dispute procedure is the choice of the parties ("au choix des parties"), but the three options listed as choices are all international arbitration. The US State Department considers this Investment Code (Law No 2002-03) to provide consent. Page 6 of this document: http://www.state.gov/documents/organization/227363.pdf

Article 7.2 "Toutefois toit différend entre une personne physique ou morale étrangère et la République Islamique de Mauritanie, relatif à l'applicaion ou 'linterprétation du présent code est réglé conformément au choix des parties, conformément à une procédure d'arbitrage et de conciliation découlant: (a) Soit des accords et traités relatifs à la protection des investissements conclus entre la République et l'Etat dont la personne physique ou morale concernée est ressortissant. (b) Soit d'un arbitrage du CIRDI, crée par la Convention, ouverte à la signature à Washington le 18 mars 1965. (c) Soit d'un tribunal arbitral Ad-Hoc qui, à...UNCITRAL."

There is a later law, in 2012, which is not the same, but also likely to be interpreted as providing consent.

Article 30. Différends relatifs à l'interprétation ou l'application du Code des Investissements

Tous les différends résultant de l'interprétation ou de l'application du présent Code sont réglés par conciliation ou dans l'impossibilité d'entente entre les parties concernées, par voie d'arbitrage, ou selon l'option de l'investisseur, par les juridictions mauritaniennes compétentes conformément aux lois et règlements de la République Islamique de Mauritanie.

Les différends entre investisseurs étrangers ou entreprises sous contrôle étranger établies en République Islamique de Mauritanie et les autorités publiques de la République islamique de Mauritanie et relatifs au présent Code pourront en outre être résolus par conciliation ou arbitrage en vertu: soit d'un commun accord entre les deux parties; soit d'accords et traités relatifs à la protection des investissements conclus entre la République Islamique de Mauritanie et l'Etat dont l'investisseur est originaire; soit d'un arbitrage de la Chambre Internationale de Médiations et d'Arbitrage de Mauritanie (CIMAM) ou du Centre International pour le Règlements des Différends relatifs aux Investissements (CIRDI), créé par la « Convention pour le Règlement des Différends relatifs aux Investissements » entre Etats et ressortissants d'autres Etats du 18 Mars 1965, ratifiée par la Mauritanie.

\begin{tabular}{|l|l|l|l|l|}
\hline Moldova & $\begin{array}{l}\text { Law on Investments in Entrepreneurial } \\
\text { Activity }\end{array}$ & 2004 & UNCTAD & No consent \\
\hline
\end{tabular}

Note: There is an earlier law (1998) that does not mention or consent to international arbitration.

Article 14. Resolution of investments disputes 
1) Investment disputes shall be resolved by mutual agreement.

2) In the event of failure to resolve the dispute by mutual agreement the latter shall be subject to resolution by a competent court instance of the Republic of Moldova or, upon mutual consent, by the ad hoc or permanent arbitration.

3) If the parties agreed to resolve the dispute at the arbitration, they shall expressly confirm this fact, specifying, if necessary, rules of practice, selected in compliance with legislation of the Republic of Moldova on arbitration.

4) If the parties agreed to resolve the dispute at ad hoc arbitration, the following rules of practice shall be taken into account:

a. Arbitration Rules of United Nations Commission on International Trade Law (UNCITRAL Rules);

b. Arbitration Rules International Chamber of Commerce of Paris, approved on January 1, 1988 (ICC

Rules);

c. other principles, norms, rules, established by the parties.

5) If the parties agreed to resolve the dispute at the permanent arbitration, there shall be taken into account international agreements, to which the Republic of Moldova makes part, including:

a. The 1958 New York Convention on the Recognition and Enforcement of International Arbitration Awards;

b. European Convention on International Commercial Arbitration of 1961 Done at Geneva;

c. The 1962 Paris Agreement Relating to Application of the European Convention on International Commercial Arbitration.

6) Labor disputes between management of enterprise with foreign investments and its employees shall be adjudicated in compliance with legislation of the Republic of Moldova, if otherwise not envisaged for foreign employees in individual labor contracts.

\begin{tabular}{|l|l|l|l|l|}
\hline Mongolia & Law on Investment & 2013 & UNCTAD & Consent \\
\hline
\end{tabular}

Article 7 (9) Unless it is provided by law or in the international treaties, to which Mongolia is a party, an investor is entitled to select an international or domestic arbitration to settle any dispute which may arise regarding the contract concluded with the state authority of Mongolia.

\begin{tabular}{|l|l|l|l|l|}
\hline Montenegro & Foreign Investment Law & 2011 & UNCTAD & No consent \\
\hline
\end{tabular}


Article 30

Any dispute arising from foreign investment shall be resolved by the competent court in Montenegro, unless the decision on establishment i.e. the agreement on investment stipulates that such disputes are settled before domestic or foreign arbitration, in compliance with international conventions.

If a contracting party is the Government, then until the Convention of the International Center for the Settlement of Investment Disputes (ICSID Convention) is signed, the disputes arising from foreign investments shall be resolved before domestic or foreign arbitration in accordance with the additional rules of the ICSID Convention for countries that are not signatories to the ICSID Convention.

If the contracting parties are domestic or foreign legal entities and natural persons, then disputes arising from foreign investments shall be resolved before domestic or international arbitration in accordance with the United Nations Commission on International Trade Law (UNCITRAL) Rules.

\begin{tabular}{|l|l|l|l|l|}
\hline Mozambique & Law on Investment & 1993 & UNCTAD & No consent \\
\hline
\end{tabular}

Note: as far as we know, this law has not been interpreted by a tribunal. The language in 25 (2) is ambiguous, but the phrase [be entitled to submission] 'upon express agreement of both parties' leads us to believe a tribunal would likely not find this provision provides consent.

Article 25. Resolution of disputes

1) Any disputes arising from the interpretation and application of this Law and its Regulations, which cannot be resolved on a friendly basis or by means of negotiation, may be submitted to the competent judicial authorities, in accordance with Mozambican legislation, for their resolution.

2) Disputes between the Government of Mozambique and foreign investors concerning authorised and realised investments in the country, which cannot be resolved on the basis provided for in paragraph 1 of this Article, shall, unless otherwise agreed, be entitled to submission for resolution through arbitration, with possible recourse, upon express agreement of both parties, to:

a. the rules of the International Convention for the Settlement of Investment Disputes between States and Nationals of other States (ICSID) adopted in Washington on 15th March 1965, or through the International Centre for the Settlement of Investment Disputes between States and Nationals of other States;

b. rules set out in the ICSID Additional Facility adopted on the 27th September 1978 by the Administrative Council of the International Centre for Settlement of Investment Disputes between States and Nationals of other States, whenever the foreign investor does not meet the requirements provided for in Article 25 of the ICSID Convention;

c. rules of arbitration of the International Chamber of Commerce based in Paris. 


\begin{tabular}{|l|l|l|l|l|}
\hline Namibia & Foreign Investment Act & 1990 & ICSID & No consent \\
\hline
\end{tabular}

Foreign Investment Act, dated December 19, 1990, as amended by Act No 24 of 1993.

Article 13. The initial certificate will likely provide for the settlement of disputes by international arbitration. Without the certificate providing for international arbitration, then the investor has access to local courts, or may agree to international arbitration with the government.

\begin{tabular}{|l|l|l|l|l|}
\hline Nepal & $\begin{array}{l}\text { Foreign Investment and Technology } \\
\text { Transfer Act 1992 }\end{array}$ & 1992 & UNCTAD & Consent \\
\hline
\end{tabular}

Section 7. Settlement of Disputes

1) If any dispute arises between a foreign investor, national investor or the concerned industry, the concerned parties shall be required to settle the dispute by mutual consultations in the presence of the Department.

2) If the dispute could not be settled in the manner as referred to in sub-section (1) above, it shall be settled by arbitration in accordance with the prevailing arbitration rules of the United Nations Commission on International Trade Law (UNCITRAL).

3) The arbitration shall be held in Katmandu, The laws of Nepal shall be application in the arbitration.

4) Notwithstanding anything contained in subsections (1), (2) and (3)above, disputes arising in regard to foreign investment made in the industries with investment as prescribed may be settled as mentioned in the foreign investment agreement.

\begin{tabular}{|l|l|l|l|l|}
\hline Nicaragua & $\begin{array}{l}\text { Ley de Promocion de Inversiones } \\
\text { Extranjeras, Ley No. 344, 2000 }\end{array}$ & 2000 & ICSID (2002-1) & $\begin{array}{l}\text { Unclear, } \\
\text { likely to be } \\
\text { interpreted } \\
\text { as } \\
\text { providing } \\
\text { consent }\end{array}$ \\
\hline
\end{tabular}

This provision does not mention specific arbitration centers, but says that any disputes may be submitted to international arbitration in accordance with what is established by regulation ("podrá someterse a Arbitraje Internacional de acuerdo con lo que se disponga reglamentariamente").

Article 8. Toda diferencia, controversia o reclamo que surja o se relacione con las inversiones extranjeras reguladas por la presente Ley, podrá someterse a Arbitraje Internacional de acuerdo con lo 
que se disponga reglamentariamente, sin perjuicio de la aplicación de las normas legales nacionales vigentes y los convenios de los que la República de Nicaragua sea parte.

\begin{tabular}{|l|l|l|l|l|}
\hline Niger & $\begin{array}{l}\text { Code des investissements en } \\
\text { Republique du Niger }\end{array}$ & 1989 & ICSID & Consent \\
\hline
\end{tabular}

This Investment Code (Ordinance No 89-19 dated December 8, 1989) is then amended in 1997, 1999, 2001.

Article 6. The settlement of disputes related to the validity, interpretation or the application of the deed of agreement and the possible determination of compensation due to the ignorance or violation of the commitments will be subject to one of the arbitration procedures hereinafter to be determined in the deed of agreement: (1) constitution of an arbitration board (specifies directions for this) (2) The possibility for the non national to remedy to ICSID created by the convention dated march 18th 1965 of the IBRD.

\begin{tabular}{|l|l|l|l|l|}
\hline Nigeria & $\begin{array}{l}\text { Nigerian Investment Promotion } \\
\text { Commission Act }\end{array}$ & 1995 & UNCTAD & Consent \\
\hline
\end{tabular}


Note: We initially coded this law as not providing consent. Then the tribunal in Interocean Oil Development Company and Interocean Oil Exploration Company v. Federal Republic of Nigeria (ICSID Case No. ARB/13/20) found that this law provided them with jurisdiction. The 'Decision on Preliminary Objections' is here: https://www.italaw.com/sites/default/files/case-documents/italaw6336.pdf As far as we know, the Interocean tribunal is the only one to have interpreted this clause, so we follow their decision.

Section 27. Dispute settlement

1) Where a dispute arises between an investor and any Government of the Federation in respect of an enterprise all efforts shall be made Procedure through mutual discussion to reach an amicable settlement.

2) Any dispute between an Investor and any Government of the Federation in respect of an enterprise to which this Act applies which is not amicably settled through mutual discussions may be submitted at the option of the aggrieved party to arbitration as follows:

a. in respect of a Nigerian investor, in accordance with the rules of procedure for arbitration as specified in the Arbitration and Conciliation Act 1988; or

b. In the case of a foreign investor, within the framework of any bilateral or multilateral agreement on investment protection to which the Federal Government and the country of which the investor is a national disputes agreed on by the parties;

c. in accordance with any other national or international machinery for the settlement of investment disputes agreed on by the parties.

3) Where in respect of any dispute, there is disagreement between the investor and the Federal Government as to the method of dispute settlement to be adopted; the International Centre for Settlement of Investment Disputes Rules shall apply.

\begin{tabular}{|l|l|l|l|l|}
\hline Oman & Foreign Capital Investment Law & 1994 & UNCTAD & No consent \\
\hline
\end{tabular}

Article 14

It may be agreed to refer any dispute between the foreign investment projects and third parties to a local or international arbitration tribunal.

\begin{tabular}{|l|l|l|l|l|}
\hline $\begin{array}{l}\text { Papua New } \\
\text { Guinea }\end{array}$ & Investment Promotion Act 1992 & 1992 & Case & No consent \\
\hline
\end{tabular}

This provision was the basis for the claim in PNG Sustainable Development Program Ltd v Papua New Guinea (ICSID Case No ARB/13/33). The tribunal found the law does not contain consent to arbitration. 
Article 39. "The Investment Disputes Convention Act (Chapter 346) implementing the ICSID Convention; applies, according to its terms, to disputes arising out of foreign investment."

The Investment Disputes Convention Act, Article 2 states: "A dispute shall not be referred to the Centre [the International Centre for Settlement of Investment Disputes (ICSID)] unless the dispute is fundamental to the investment itself"

\begin{tabular}{|l|l|l|l|l|}
\hline Paraguay & Ley de Inversiones & 1992 & UNCTAD & No consent \\
\hline
\end{tabular}

Artículo 9

Los inversionistas nacionales y extranjeros, así como las entidades del Estado, incluyendo los entes autárquicos y las demás entidades de derecho público que contrataren con el inversor extranjero, podrán acordar someter sus diferencias a tribunales arbitrales nacionales o internacionales, de conformidad con las normas legales nacionales e internacionales pertinentes.

\begin{tabular}{|l|l|l|l|l|}
\hline Qatar & $\begin{array}{l}\text { Law on Organization of Foreign } \\
\text { Capital in the Economic Activity }\end{array}$ & 2000 & UNCTAD & No consent \\
\hline
\end{tabular}

Article 11

It may be agreed to solve any dispute arising between the investor and any other party through Local or international arbitration commission.

\begin{tabular}{|l|l|l|l|l|}
\hline $\begin{array}{l}\text { Russian } \\
\text { Federation }\end{array}$ & Law on Foreign Investments & 1999 & UNCTAD & $\begin{array}{l}\text { Unclear, } \\
\text { likely to be } \\
\text { interpreted } \\
\text { as no } \\
\text { consent }\end{array}$ \\
\hline
\end{tabular}

Note: as far as we know, no tribunal has interpreted this provision yet.

In 2014, Anton Asoskov provided an expert opinion for three PCA arbitrations (Hulley Enterprises Limited v. The Russian Federation, PCA Case No. AA 226; Veteran Petroleum Limited v. The Russian Federation, PCA No AA 228; Yukos Universal Limited v. The Russian Federation, PCA Case No. AA 227). Jurisdiction was based on the Energy Charter Treaty, but his expert opinion also addresses the 1999 law (pages 23-30) available here (https://www.italaw.com/sites/default/files/casedocuments/italaw4153.pdf). Asoskov finds the law does not provide consent to arbitration.

A tribunal may well come to different conclusion than the Russian Supreme Court, but the Supreme Court touched on Article 10 in a case on forum selection (Pages 33-34 here: 
http://vsrf.ru/Show_pdf.php?Id=11489). The Court was deciding if a Russian court or foreign court had jurisdiction to recover a loan; it referred to Article 10 and implied that forum selection comes in a separate instrument.

Article 10. The guarantee of proper resolution of a dispute arising from performance of foreign investment and entrepreneurial activities by a foreign investor in the territory of the Russian Federation.

A foreign investor's dispute arising in connection with the implementation of investment and entrepreneurial activities in the territory of the Russian Federation shall be resolved in compliance with international treaties of the Russian Federation and federal laws in the court or arbitration court or in an international arbitration court.

\begin{tabular}{|l|l|l|l|l|}
\hline Rwanda & $\begin{array}{l}\text { Law Relating to Investment Promotion } \\
\text { And Facilitation }\end{array}$ & 2015 & UNCTAD & No consent \\
\hline
\end{tabular}

Article 9. Dispute settlement

Any dispute arising between a foreign investor and one or more public organs in connection with a registered investment enterprise shall be amicably settled.

When an amicable settlement cannot be reached, parties shall refer the dispute to an arbitration agency as agreed upon in a written agreement between both parties.

Where no arbitration procedure is provided under a written agreement, both parties shall refer the matter to the competent court.

\begin{tabular}{|l|l|l|l|l|}
\hline Sierra Leone & The Investment Promotion Act, 2004 & 2004 & UNCTAD & Consent \\
\hline
\end{tabular}

Section 16

1) Where a dispute arises between an investor and the Government in respect of an investment in a business enterprise or in respect of an investment obstructed or delayed by Government, the parties will use their best efforts to settle such dispute amicably.

2) Where any dispute between an investor and the Government in respect of a business enterprise is not settled amicably, it may be submitted at the option of the aggrieved party to arbitration as follows-

a. in accordance with the rules of procedure for arbitration of the United National Commission on International Trade Laws (UNCITRAL). 
b. in the case of a foreign investor within the framework of any bilateral or multilateral agreement on investment protection to which the Government and the country of which the investor is a national are parties; or

c. in accordance with any other national or international machinery for the settlement of investment disputes as the parties may agree.

3) Where any dispute between an investor and a nongovernmental body in respect of an enterprise is not settled amicably, and where no recourse is available through arbitration or previously established contracts or other legal instruments, then the matter shall be referred to the relevant legal authority within Sierra Leone for settlement, in accordance with the law binding such transaction.

\begin{tabular}{|l|l|l|l|l|}
\hline $\begin{array}{l}\text { Solomon } \\
\text { Islands }\end{array}$ & Foreign Investment Act 2005 & 2005 & UNCTAD & No consent \\
\hline
\end{tabular}

Section 28. Disputes

1) The law of Solomon Islands applies to disputes involving foreign investors who conduct investment activities.

2) A dispute involving a foreign investor who conducts an investment activity shall be dealt with under the law of Solomon Islands as if it were a dispute involving a citizen of Solomon Islands.

3) To the extent that the Convention of Settlement of Investment Disputes (which was signed by Solomon Islands in Washington on 12 November 1979 and acceded to by Solomon Islands on 8 October 1981) is not inconsistent with the law of Solomon Islands, it applies to, and shall be complied with by, foreign investors who conduct investment activities as a law of Solomon Islands.

\begin{tabular}{|l|l|l|l|l|}
\hline Somalia & The Foreign Investment Law & 1987 & UNCTAD & Consent \\
\hline
\end{tabular}

Article 19. Settlement of disputes

1) Disputes in respect of the implementation of this law shall be settled:

a. In a manner to be agreed upon with the investor, or in the absence of such agreement;

b. Within the framework of the agreements in force between the Somali Democratic Republic and the investor's home country, or, in the absence of (a) and (b);

c. Within the framework of the Convention for the Settlement of Investment Disputes between the State and the Nationals of Other Countries, to which Somalia has adhered by virtue of Law No. 11 of 1967 , when such convention applies. 
2) In the absence of agreements or convention as per paragraph 1 of this Article, disputes shall be settled through arbitration. An arbitration board shall be established, comprising one member on behalf of each disputing party and a third member acting as a chairman, to be jointly named by the said two members. In the case that the disputing parties fail to agree on the nomination of the chair-man within 30 days of the date of the nomination of the second member, the chairman shall be appointed by the President of the Supreme Court of Somalia. The Arbitration Board shall lay down its rules of procedure unrestricted by the rules contained in the civil and commercial code of procedures, save for the rules which relate to the basic guarantees and principles of litigation. The Board shall see to it that the disputes be expediently resolved. Awards shall be rendered by majority vote, and shall be final and binding on both parties and enforceable as any other final judgment. The Arbitration Board shall decide who shall bear the arbitration costs.

\begin{tabular}{|l|l|l|l|l|}
\hline South Sudan & The Investment Promotion Act, 2009 & 2009 & UNCTAD & Consent \\
\hline
\end{tabular}

Article 39. Dispute Resolutions

1) The courts of Southern Sudan shall have jurisdiction over the resolution of business disputes.

2) Notwithstanding the provisions of subsections (1) above, parties to an investment dispute may specify any arbitration or other dispute resolution mechanisms upon which they may agree, within or outside the courts.

3) Where a dispute rises between an investor and the Government in respect of an enterprise, all efforts shall be made to reach an amicable settlement.

4) Any dispute between an investor and the Government in respect of an enterprise to which this Act applies but not amicably settled may be submitted at the option of the aggrieved party to arbitration as follows -

a. in accordance with the rules and procedures for arbitration by the International Centre for the Settlement of Investment Disputes; or

b. in case of a foreign investor, within the frame work of any bilateral or multilateral agreement on investment protection to which the Government and the country of which the investors is a national, are parties; or

c. in accordance with any other national or international machinery for the settlement of investment disputes, agreed to by the parties.

5) Any arbitral award made in respect of arbitration proceeding conducted in terms of this section shall be final and bindings on the parties, without such a ward having to be made an order of the court and the parties shall give effect to such award forthwith. 
6) Notwithstanding the provisions of subsections (5) above, a party in whose favour an award has been made shall be entitled to apply to the High Court for an order to compel the other party to comply with that award, and the High Court shall have the jurisdiction to grant such as order.

\begin{tabular}{|l|l|l|l|l|}
\hline Sudan & $\begin{array}{l}\text { National Investment Encouragement } \\
\text { Act 2013 }\end{array}$ & 2013 & UNCTAD & No consent \\
\hline
\end{tabular}

Article 39. Resolving of investment disputes

1) With exceptions to the disputes governed by the terms of the agreements stipulated for in item (2), if any legal dispute ensues in respect of the investment, shall be initially presented to the competent court unless the parties agree to refer it to arbitration or reconciliation.

2) The terms of the Unified Agreement for the Investment of Arabic Capital in Arab States 1980, Agreement for Settlements of Investment Disputes among Arab States 1974, Agreement for Settlement of Investment Disputes Among States and Nationals of other Countries 1965, General Agreement for Economical, Technical and Commercial Co-operation among Members Sates of Islamic Conference 1977 or any other agreement in this respect where Sudan is a party thereof, shall be applicable on any legal dispute arises directly from any of the said agreements.

\begin{tabular}{|l|l|l|l|l|}
\hline $\begin{array}{l}\text { Syrian Arab } \\
\text { Republic }\end{array}$ & Investment Promotion Law & 2007 & UNCTAD & $\begin{array}{l}\text { Ambiguous, } \\
\text { but may be } \\
\text { interpreted } \\
\text { by a } \\
\text { tribunal as } \\
\text { providing } \\
\text { consent }\end{array}$ \\
\hline
\end{tabular}

Note: as far as we know, no tribunal has interpreted this provision yet.

Article 7

a) Investment-related disputes between an investor and Syrian public bodies and institutions shall be settled amicably. If the disputing parties could not reach a solution amicably in three months from the date of making a written notification for an amicable settlement by one of the disputing parties, each of them shall have the right to take the case to one of the following:

Arbitration.

Competent Syrian Courts. 
Arab Investment Court created pursuant to the Unified Agreement for the Investment of Arab Capitals in the Arab states in 1980.

Investment Insurance and Protection Agreement signed by Syria and the investor's country, or any Arab or international organization.

b) All investment-related disputes shall be considered by the competent court as summary proceedings.

Earlier Law: Law No 10 of 1991 (and Law No 7 of May 7, 2000 amending Investment Law No 10 or 1991). No consent.

No mention of international arbitration. Then, possible resort to Arab Investment Court is mentioned in 2000 amendments.

\begin{tabular}{|l|l|l|l|l|}
\hline Tajikistan & $\begin{array}{l}\text { The Law of the Republic of Tajikistan } \\
\text { on Investments }\end{array}$ & 2007 & UNCTAD & No consent \\
\hline
\end{tabular}

Article 22. Settlement of investment disputes

1) Investment disputes between participants of investment activity are solved according to the conditions stipulated by contracts, concluded between the parties. In case of absence of the specified contracts, investment disputes between participants of investment activity are settled as far as possible, by consultation of the parties.

2) In case of impossibility of the settling of investment disputes according to the concluded contracts, disputes will be settled in the courts of the Republic of Tajikistan, and also in the international arbitration court, the arbitration court determined under the consent of the parties, according to acts of the Republic of Tajikistan and is international-legal acts.

Earlier version: Law on Foreign Investments in the Republic of Tajikistan (2000). Same dispute settlement provision included in 1994 ICSID.) No consent.

Article 36. Local courts unless provided for otherwise by treaty.

\begin{tabular}{|l|l|l|l|l|}
\hline Tanzania & Tanzania Investment Act & 1997 & UNCTAD & No consent \\
\hline
\end{tabular}

Biwater Gauff (Tanzania) Ltd v. United Republic of Tanzania, ICSID Case No. ARB/05/22, Award, 24 July 2008 (finding that Section 23.2 of the Tanzania Investment Act which provided that "A dispute between a foreign investor and the [Tanzania Investment] Centre may be submitted to arbitration in accordance with any of the following methods as may be mutually agreed by the parties, that is to say - 
(b) in accordance with the rules of procedure for arbitration of the International Centre for the Settlement of Investment Disputes" did not constitute a standing unilateral offer to arbitrate.)

Tribunal in Biwater Gauff Ltd v United Republic of Tanzania found the provision did not embody a standing unilateral offer to arbitrate by Tanzania; the tribunal emphasized the language "as may be mutually agreed by the parties" was an insurmountable obstacle. (noted by Potestà too)

Section 23. Settlement of disputes

1) Where a dispute arises between a foreign investor and the Centre or the Government in respect of a business enterprise, all efforts shall be made to settle the dispute through negotiations for an amicable settlement.

2) A dispute between a foreign investor and the Centre or the Government in respect of a business enterprise which is not settled through negotiations may be submitted to arbitration in accordance with any of the following methods as may be mutually agreed by the parties, that is to say-

a. in accordance with arbitration laws of Tanzania for investors;

b. in accordance with the rules of procedure for arbitration of the International Centre for the Settlement of Investment Disputes;

c. within the framework of any bilateral or multilateral agreement on investment protection agreed to by the Government of the United Republic and the Government of the Country the Investor originates.

\begin{tabular}{|l|l|l|l|l|}
\hline Timor-Leste & Private Investment Law & 2005 & ICSID & Consent \\
\hline
\end{tabular}

Article 23 (2) Os diferendos entre o Estado e os investidores externos de nacionalidade estrangeira, que não possam ser solucionados nos termos previstos no número anterior, salvo acordo em contrário, são resolvidos por via da arbitragem em conformidade com as regras da Convenção Internacional de Resolução de (CIRDI).

\begin{tabular}{|l|l|l|l|l|}
\hline Togo & Code Des Investissements & 1989 & ICSID & Consent \\
\hline
\end{tabular}

Potestà considers this article as unambiguous consent.

Le consentement des parties à la compétence du CIRDI requis par les instruments le régissant, est constitué en ce qui concerne la République togolaise par le présent article et, en ce qui concerne la personne intéressée, est exprimé dans la demande d'agrément.

\begin{tabular}{|l|l|l|l|l|}
\hline Tonga & Foreign Investment Act 2002 & 2002 & UNCTAD & No consent \\
\hline
\end{tabular}


Article 16. Investment guarantees

1) The provisions of the Arbitration Act 1996 (UK) shall apply to any arbitration under this Act.

2) Subject to this Act and any other laws, the Convention on the Settlement of Investment Disputes shall have the force of law in Tonga.

\begin{tabular}{|l|l|l|l|l|}
\hline Turkey & Foreign Direct Investment Law & 2003 & UNCTAD & No consent \\
\hline
\end{tabular}

Article 3

a) Freedom to Invest and National Treatment

Unless stipulated by international agreements and other special laws:

Foreign investors are free to make foreign direct investments in Turkey,

Foreign investors shall be subject to equal treatment with domestic investors.

b) Expropriation and Nationalisation

Foreign direct investments shall not be expropriated or nationalised, except for public interest and upon compensation in accordance with due process of law.

c) Transfers

Foreign investors can freely transfer abroad: net profits, dividends, proceeds from the sale or liquidation of all or any part of an investment, compensation payments, amounts arising from license, management and similar agreements, and reimbursements and interest payments arising from foreign loans through banks or special financial institutions.

d) Access to Real Estate

[Annuled]

e) Dispute Settlement

For the settlement of disputes arising from investment agreements subject to private law and investment disputes arising from public service concessions contracts and conditions which are concluded with foreign investors, foreign investors can apply either to the authorised local courts, or to national or international arbitration or other means of dispute settlement, provided that the conditions in the related regulations are fulfilled and the parties agree thereon. 


\begin{tabular}{|l|l|l|l|l|}
\hline Uganda & Investment Code Act & 1991 & UNCTAD & No consent \\
\hline
\end{tabular}

Section 28. Settlement of disputes

1) Where a dispute arises between a foreign investor and the authority or the Government in respect of a licensed business enterprise, all efforts shall be made to settle the dispute through negotiations for an amicable settlement.

2) A dispute between a foreign investor and the authority or the Government in respect of a licensed business enterprise which is not settled through negotiations may be submitted to arbitration in accordance with the following methods as may be mutually agreed by the parties:

a. in accordance with the rules of procedure for arbitration of the International Centre for the Settlement of Investment Disputes;

b. within the framework of any bilateral or multilateral agreement on investment protection to which the Government and the country of which the investor is a national are parties; or

c. in accordance with any other international machinery for the settlement of investment disputes.

3) The licence in respect of an enterprise may specify the particular mode of arbitration to be resorted to in the case of a dispute relating to that enterprise, and that specification shall constitute the consent of the Government, the authority or their respective agents and the investor to submit to that mode and forum of arbitration.

4) Where the parties to a dispute do not agree on the mode or forum for arbitration, the party aggrieved by compulsory acquisition or possession or the amount of compensation payable, or in respect of any other matter relating to the business enterprise may apply to the High Court for the determination of any of the following:

a. his or her interest or right;

b. the legality of the taking of the possession or acquisition of the property, interest or right;

c. the amount of compensation to whi8ch he or she is entitled and the prompt payment of that compensation;

d. any other matter in dispute relating to the business enterprise.

\begin{tabular}{|l|l|l|l|l|}
\hline Uzbekistan & $\begin{array}{l}\text { Law on Guarantees and Measures of } \\
\text { Protection of Foreign Investors' Rights }\end{array}$ & 1998 & UNCTAD & No consent \\
\hline
\end{tabular}


The tribunal in Metal-Tech Ltd. v. The Republic of Uzbekistan (ICSID ARB/10/3) examined this law and concluded 'that Article 10 of the Law of Guarantees does not provide the basis of consent to ICSID jurisdiction.' (at 388, available here: http://cisarbitration.com/wp-content/uploads/2015/11/METALTECH-LTD.-v.-THE-REPUBLIC-OF-UZBEKISTAN.pdf )

This law was also the basis for the claim made in Newmont USA Limited and Newmont (Uzbekistan) Limited v. Republic of Uzbekistan, ICSID Case No. ARB/06/20. This claim settled, with Uzbekistan paying $\$ 80$ million, and Newmont transferring its stake to Uzbekistan.

https://www.reuters.com/article/us-newmont-uzbekistan/gold-miner-newmont-resolves-dispute-withuzbekistan-idUSN2336630420070723

The Metal-Tech tribunal further noted (at 383): "To the Tribunal, Article 10 does not embody Uzbekistan's consent to submit disputes to ICSID arbitration independently of the BIT. Paragraph (1) of Article 10 merely states that a dispute which the Parties are unable to resolve amicably may be resolved by the Economic Court of Uzbekistan or through arbitration. It contains no expression of consent to a particular arbitral mechanism. More specifically, it embodies no offer by the State to submit to dispute settlement in the ICSID framework; ICSID is not even mentioned. The Tribunal notes that statutory provisions more specific than Article 10 - even provisions expressly naming ICSID - have been held not to contain state consent to ICSID arbitration."

Article 10. Settlement of disputes

Dispute associated with foreign investments (investment dispute) directly or indirectly, can be settled on agreement of the parties by consultation between them. If the parties will not be able to achieve agreed settlement, than such dispute should be settled either by an economic court of the Republic of Uzbekistan or by arbitration in accordance with the rules and procedures of international agreements (conventions) on settlement of investment disputes, to which the Republic of Uzbekistan has been joined.

The parties involved in investment dispute can, on mutual agreement, determine the authority settling such dispute, as well as a county which can execute arbitration legal procedure of investment dispute.

Foreign investors' disputes, not associated with their investment activity on the territory of the Republic of Uzbekistan, shall be settled in accordance with the legislation of the Republic of Uzbekistan except for cases when other procedure for dispute settlement is provided by an agreement in keeping with the rules of international law.

\begin{tabular}{|l|l|l|l|l|}
\hline Venezeula & $\begin{array}{l}\text { Ley de Promoción y Protección de } \\
\text { Inversiones }\end{array}$ & 1999 & Cases & No consent \\
\hline
\end{tabular}


Venezuela's domestic law has been the basis for multiple claims, but to our knowledge, tribunals have declined jurisdiction. Cases include: Brandes Investment Partners, LP v. Bolivarian Republic of Venezuela ICSID Case ARB/08/3; Cemex Caracas II Investments B.V. v. Bolivarian Republic of Venezuela, ICSID Case No. ARB/08/15; and Mobil v Venezuela.

The Mobil v. Venezuela tribunal decided that Article 22 of the Venezuelan law did not provide consent to arbitration. They quoted Article 22 of the Venezuelan law:

"Disputes arising between an international investor whose country of origin has in effect with Venezuela a treaty or agreement on the promotion and protection of investments, or disputes to which are applicable the provision of the Convention Establishing the Multilateral Investment Guarantee Agency (OMGI-MIGA) or the Convention on the Settlement of Investment Disputes between States and Nationals of Other States (ICSID), shall be submitted to international arbitration according to the terms of the respective treaty or agreement, if it so provides, without prejudice to the possibility of making use, when appropriate, of the dispute resolution means provided for under the Venezuelan legislation in effect."

\begin{tabular}{|l|l|l|l|l|}
\hline Yemen & Investment Law & 2010 & UNCTAD & Consent \\
\hline
\end{tabular}

Article 26

a) Yemeni commercial courts shall be the competent authority to resolve investment disputes in accordance with the provisions of this law.

b) Without prejudice to the provisions of the previous paragraph, the parties to an investment dispute may agree to settle their dispute amicably or through arbitration.

c) In the event any dispute arises between the investor and the government with respect to the project, the dispute may be settled amicably. Should an amicable settlement not be reached, the dispute shall be referred to arbitration in accordance with the following:

The arbitration rules and procedures of any national or regional recognized arbitration center.

The applicable arbitration rules and procedures of the United Nations Commission on International Trade Law (UNCITRAL).

\begin{tabular}{|l|l|l|l|l|}
\hline Zambia & Zambia Development Agency Act & 2006 & UNCTAD & No consent \\
\hline
\end{tabular}


Article 21. Settlement of disputes

Any dispute arising as a consequence of an investment under this Act shall be settled in accordance with the Arbitration Act.

The Arbitration Act of 2000 does not itself provide consent to investor-state arbitration; an arbitration agreement must be in a contract or in the form of a separate agreement. 


\section{Appendix B. Descriptive statistics}

Table B1. Summary statistics, models 4-6, Table 2

\begin{tabular}{lccccccc}
\hline Statistic & $N$ & Mean & SD & Min & P25 & P75 & Max \\
\hline FIAS, last 3 yrs. & 4546 & 0.046 & 0.209 & 0 & 0 & 0 & 1 \\
FIAS, last 5 yrs. & 4546 & 0.064 & 0.244 & 0 & 0 & 0 & 1 \\
Rigorous and imp. adm. & 3866 & 0.585 & 1.548 & -3.631 & -0.657 & 1.768 & 4.623 \\
Accountability & 3866 & 0.654 & 0.960 & -1.693 & -0.119 & 1.503 & 2.191 \\
GDP(log) & 4429 & 23.789 & 2.541 & 17.276 & 21.933 & 25.814 & 30.440 \\
GDP per capita(log) & 4429 & 8.431 & 1.538 & 4.749 & 7.135 & 9.672 & 11.886 \\
Time since indep.(log) & 4539 & 3.991 & 1.265 & 0 & 3.258 & 4.787 & 7.609 \\
Regime durability(log) & 3804 & 2.637 & 1.304 & 0 & 1.792 & 3.584 & 5.333 \\
ISDS claims, cum. & 4546 & 0.798 & 3.618 & 0 & 0 & 0 & 59 \\
IIAs signed, cum. & 4546 & 22.824 & 23.404 & 0 & 4 & 35 & 109 \\
IBRD loans(log) & 4513 & 11.176 & 9.808 & 0 & 0 & 20.016 & 24.366 \\
\hline
\end{tabular}


Table B2 - Summary statistics, models 4-6, Table 2

\begin{tabular}{lccccccc}
\hline Statistic & $N$ & Mean & SD & Min & P25 & P75 & Max \\
\hline FIAS, last 3 yrs. & 4942 & 0.050 & 0.219 & 0 & 0 & 0 & 1 \\
FIAS, last 5 yrs. & 4942 & 0.073 & 0.260 & 0 & 0 & 0 & 1 \\
Rigorous and imp. adm. & 4249 & 0.514 & 1.509 & -3.631 & -0.655 & 1.647 & 4.623 \\
Accountability & 4249 & 0.625 & 0.945 & -1.693 & -0.134 & 1.431 & 2.191 \\
GDP( $($ og) & 4825 & 23.816 & 2.510 & 17.276 & 22.036 & 25.770 & 30.440 \\
GDP per capita(log) & 4825 & 8.375 & 1.532 & 4.749 & 7.103 & 9.567 & 11.886 \\
Time since indep.(log) & 4935 & 3.996 & 1.242 & 0 & 3.258 & 4.787 & 7.609 \\
Regime durability(log) & 4187 & 2.615 & 1.297 & 0 & 1.792 & 3.584 & 5.333 \\
ISDS claims, cum. & 4942 & 0.852 & 3.607 & 0 & 0 & 0 & 59 \\
IIAs signed, cum. & 4942 & 22.881 & 23.341 & 0 & 5 & 34 & 109 \\
IBRD loans(log) & 4909 & 11.707 & 9.791 & 0 & 0 & 20.209 & 24.366 \\
\hline
\end{tabular}


Table B3 - Bivariate correlations between independent variables from regression models in Table 2

\begin{tabular}{|c|c|c|c|c|c|c|c|c|c|}
\hline & (1) & (2) & (3) & (4) & (5) & (6) & (7) & (8) & (9) \\
\hline (1) Rigorous and imp. adm. & 1.00 & & & & & & & & \\
\hline (2) Accountability & 0.75 & 1.00 & & & & & & & \\
\hline (3) GDP (log) & 0.49 & 0.48 & 1.00 & & & & & & \\
\hline (4) GDP per capita (log) & 0.71 & 0.57 & 0.71 & 1.00 & & & & & \\
\hline (5) Time since indep. $(\log )$ & 0.39 & 0.38 & 0.49 & 0.37 & 1.00 & & & & \\
\hline (6) Regime durability (log) & 0.47 & 0.27 & 0.43 & 0.53 & 0.35 & 1.00 & & & \\
\hline (7) Arbitration claims, cum. & 0.05 & 0.13 & 0.21 & 0.11 & 0.07 & 0.10 & 1.00 & & \\
\hline (8) IIAs signed, cum. & 0.29 & 0.25 & 0.40 & 0.35 & 0.22 & 0.25 & 0.22 & 1.00 & \\
\hline (9) IBRD loans (log) & -0.61 & -0.40 & -0.42 & -0.75 & -0.19 & -0.39 & 0.03 & -0.20 & 1.00 \\
\hline
\end{tabular}




\section{Appendix C. Robustness checks}

We conduct a range of additional checks to verify our findings. As a standard rule, we use models 2 and 5, and sometimes also models 3 and 6 from Table 2 in our robustness checks.

We first run two sets of placebo tests to further assess the strength of the claim to causal inference we make in our main analysis. The first set of tests assess how our findings are influenced by manipulating the year of our event of interest - i.e. mention or consent to arbitration in domestic investment laws. Figures $\mathrm{C} 1$ to $\mathrm{C} 4$ depict how the regression coefficient and corresponding significance levels for our two FIAS variables change when we move the date of consent or mention of arbitration in domestic investment laws five years backward and five years forward.51 The markers depict regression coefficients and the whiskers represent $99.5 \%$ confidence intervals. Each plot exhibits the same tendency. While the relationship between completed FIAS projects on domestic legal reform and adoption of arbitration clauses in domestic investment laws is statistically significant in the years immediately before and after the actual date of mention or consent (which is not surprising, given the slow nature of domestic legal reform processes), both the magnitude and statistical significance of this relationship declines as we move away from the actual year in which the law was passed. Around plus/minus two years after the actual date of mention or consent, the statistical relationship is no longer significant.

The second set of placebo tests assess whether there is a statistical relationship between FIAS advisory projects and variations in another class of domestic laws: environmental legislation. For data on environmental legislation, we rely on ECOLEX, an information service

51 In Figure C3, we had to drop the tests where the year of consent was moved three, four and five years forward. The coefficient in these models was so small that the whisker plot became unreadable. 
on environmental law operated by the Food and Agriculture Organization of the United Nations (FAO), the International Union for Conservation of Nature (IUCN) and the United Nations Environment Programme (UNEP).52 We use two dependent variables; one that counts all environmental acts at the country-level between 1986 and 2015, and one that counts only legislative acts in this same period. We follow Berge and Berger (2019) in logging each count variable, as a small change in regulatory activity from one year to the next should be of less importance if the total load of environmental legislative acts in a country is already very high than if the baseline level of legislative activity is low. We also rely on Berge and Berger (2019) for correct model specification and confounding covariates. We use pooled cross-section ordinary least squares (OLS) regression with country fixed effects, year fixed effects and a lagged dependent variable in all models. 53 The results from the second set of placebo tests is reported in Table $\mathrm{C} 1$. The results are unequivocal: there is no relationship between finalized FIAS advisory projects on domestic legal reform and variations in domestic environmental regulatory or legislative activity, regardless of how environmental legislation is measured, or which version of the FIAS variable is applied.

Next, we run two sets of tests assessing whether the relationship between FIAS technical assistance and arbitration clauses in domestic investment laws is part of a wider development trend driven by the broader advisory complex and donor community; or whether it is riven by more investment-specific economic factors and the country-level.

52 ECOLEX is the most comprehensive global source of information on environmental law, and it has a repository of all available domestic environmental legislation and regulations enacted around the world. See: https://www.ecolex.org/.

${ }_{53}$ See in-depth reasoning behind each covariate in Berge and Berger (2019). We use a skimmed down version of their covariate set. 
To control for the broader advisory complex, we introduce two new covariates. To assess whether arbitration clauses is FIAS' brainchild, or whether other IOs also push for this same type of reform, we include a variable that captures whether a country has received an investment policy review (IPR) from UNCTAD in the last three years.54 To measure the overall donor activity in countries, we control for the log of the net inflows of official development assistance (ODA).55 Tables $\mathrm{C} 2$ and $\mathrm{C} 3$ reports the findings from Cox regression models including these two variables, the former using time-to-mention as dependent variable and the latter using time-toconsent.

A couple of things are worth noting when examining the results in Table C3 and C4. First, the effect of FIAS advisory projects on the domestic law adoption rate is not influenced in any significant way by controlling for the broader advisory or donor complex (compare the baseline models - 15 and 19 - with the other models in the Tables C3 and C4 respectively). Second, receiving an investment policy review from UNCTAD does not seem to independently influence the rate of adoption of domestic investment laws with arbitration clauses. Third, increases in the total inflow of ODA does have an independent effect on the rate of law adoption, with more ODA leading to an increase in the rate of adoption of domestic investment laws with mention or consent to arbitration. As such, there does seem to be some other, donor-driven

${ }_{54}$ UNCTAD is a key actor in the international advisory complex on investment policy and law. In addition to hosting forums for deliberation between government officials such as the bi-annual World Investment Forum, and providing extensive data services on international investment agreements and investor-state dispute settlement cases (see: https://investmentpolicy.unctad.org/), they have since 1999 conducted extensive country-level investment policy reviews (IPRs) that often include very specific reform suggestions. These reviews take into account the entirety of the regulative framework for foreign direct investment, thereunder any domestic investment law or code in force. See: https://investmentpolicy.unctad.org/investment-policy-review.

${ }_{55}$ Data taken from the World Development Indicators, see:

https://datacatalog.worldbank.org/dataset/world-development-indicators. As the ODA variable can take on negative values, we use an alternative log-transformation: $y=\ln \left(x+\sqrt{x^{2}+1}\right)$ (Busse and Hefeker 2007: 404-405). 
factors that influence countries propensity to adopt domestic investment laws with arbitration clauses, but these do not in any way confound the influence of FIAS. It is more likely that they work in tandem with FIAS advice.

To control for more investment-specific factors at the country-level, we introduce four additional control variables: the log of total inflows of foreign direct investment (FDI);56 trade as percentage of GDP; annual use of International Monetary Fund (IMF) credits; and, annual GDP growth.57 Tables $\mathrm{C} 4$ and $\mathrm{C} 5$ reports the findings from Cox regression models including these additional control variables, the former using time-to-mention as dependent variable and the latter using time-to-consent. While some of the controls reduce the size of the FIAS-effect on the rate of adoption of investment laws somewhat, the high levels of significance are retained throughout. The totality of the models in Table C4 and C5 indicate that our findings are robust to more investment-specific economic control variables.

Next, we assess whether our findings are robust to the use of other estimation methods. We first run parametric survival models, assuming an exponential survival distribution. Table C6 report results from four models using both time-to-mention and time-to-consent as dependent variables. All four models reproduce the effect of FIAS assistance on the rate of adoption of domestic investment laws with arbitration clauses. We then use mention of/consent to arbitration in domestic laws as binary outcome variables, and run logit models with year fixed effects, and rare-event logit models. 58 Tables $\mathrm{C} 7$ and $\mathrm{C} 8$ report the results from these regressions, and all

${ }_{56}$ FDI data was taken from UNCTAD, see: https://unctad.org/en/Pages/DIAE/FDI\%20Statistics/FDIStatistics.aspx.

57 Data on trade, IMF credits and GDP growth were taken from the World Development Indicators, see: https://datacatalog.worldbank.org/dataset/world-development-indicators. 58 Logit models are known to suffer from small-sample bias (Firth 1993; King and Zeng 2001). In our data, the events in question become very rare when using mention of or consent to arbitration as binary outcome variables with a panel data set-up (72 of 4546 observations when using the mention-version of our dependent variable, and 36 of 4546 observations when using consent). We use the firthlogit 
eight models reproduce a strong, significant relationship between FIAS and mention of/consent to arbitration in domestic investment laws. Our findings do not seem to be driven by our choice of estimator.

Finally, we run two sets of sensitivity tests. In the first set we remove our control variables one-by-one, and see how that influences the FIAS regression coefficient. Figures C5 and C6 represent 10 replications of each of models 2 and 5 in Table 2, each removing one of the ten control variables. Neither set of replications indicate that the relationship between FIAS and domestic investment law adoption rates is driven by our choice of control variables. In the second set of sensitivity tests, we use a jackknife procedure to remove each observed country spell from the sample one-by-one. Figures C7 and C8 plot the density of the coefficients from 156 replications of each of models 2 and 5 in Table 2 . The density of each set of coefficients is very high, and the maximum fluctuation of the regression coefficients in each set is only about plus/minus 0.1 . Our results are remarkably robust to the influence of individual country spells.

All in all, our robustness checks lend strong support to the conclusions we reach in our article. In particular, the two sets of placebo tests, and the tests controlling for the broader advisory complex significantly strengthens our belief that the relationship between FIAS technical assistance and adoption of domestic investment laws with arbitration clauses is indeed of a causal nature.

\section{References}

Berge, T. L., \& Berger, A. (2019). Does investor-state dispute settlement lead to regulatory chill of domestic environmental regulation? The role of respondent state capacity. Paper

command in STATA, which uses penalized maximum likelihood estimation instead of the maximum likelihood estimation used in the standard logistic regression model. 
presented at the 2019 Political Economy of International Organizations Annual Conference.

Busse, C., \& Hefeker, C. (2007). Political risk, institutions and foreign direct investments. European Journal of Political Economy, 23(2), 397-415.

King, G., and Zeng, L. (2001). Logistic Regression in Rare Events Data. Political Analysis, 9(2), 137-163.

Firth, D. (1993). Bias reduction in maximum likelihood estimates. Biometrika, 80(1), 27-38. 


\section{Tables and Figures}

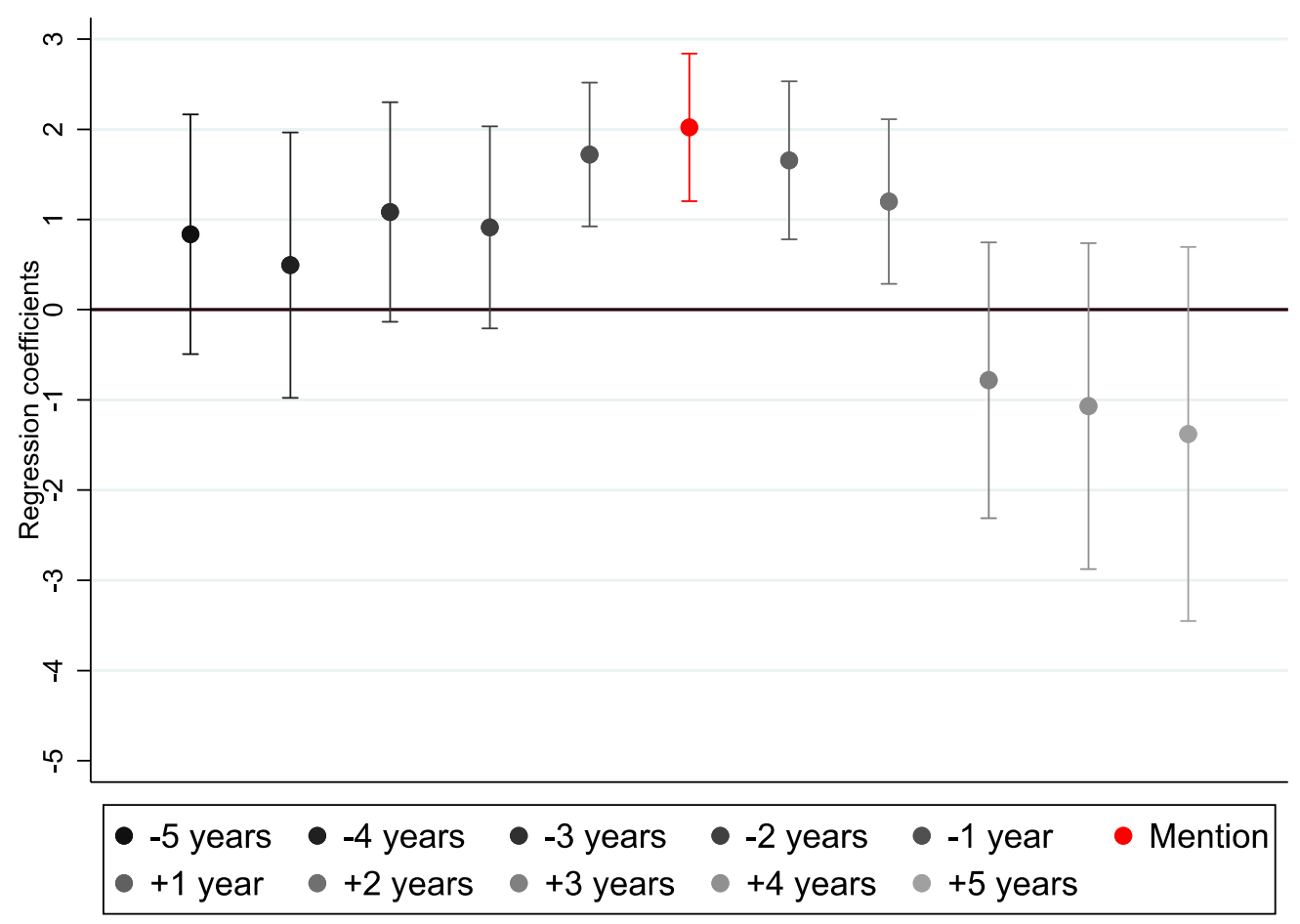

Figure C1. Placebo tests manipulating the year of mention five years backward and five years forward. Replications based on model 2 in Table 2. Markers represent regression coefficients for FIAS advisory projects completed in the last three years, and the whiskers represent $99.5 \%$ confidence intervals. 


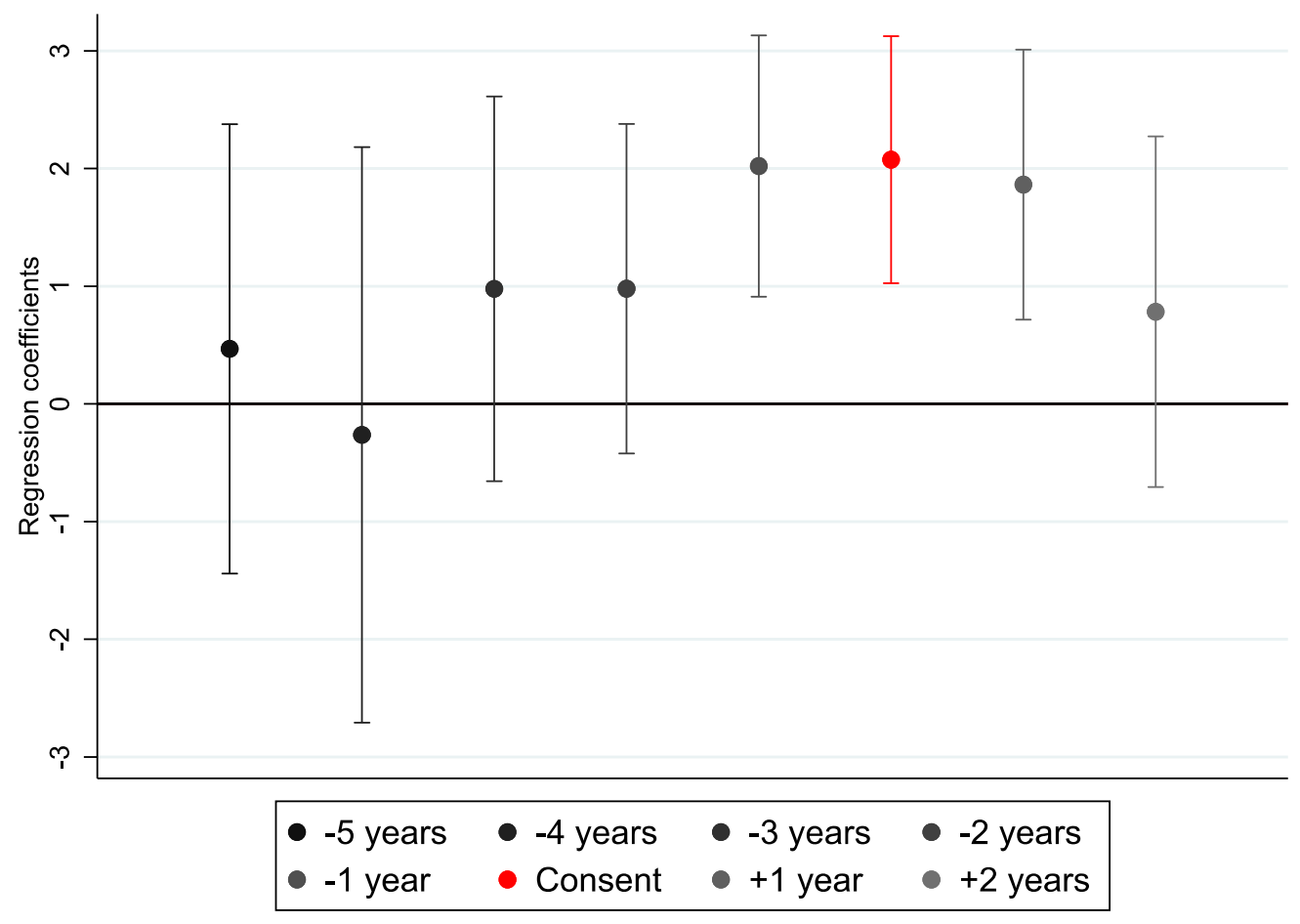

Figure C2. Placebo tests manipulating the year of mention five years backward and two years forward. Replications based on model 3 in Table 2. Markers represent regression coefficients for FIAS advisory projects completed in the last five years, and the whiskers represent $99.5 \%$ confidence intervals. 


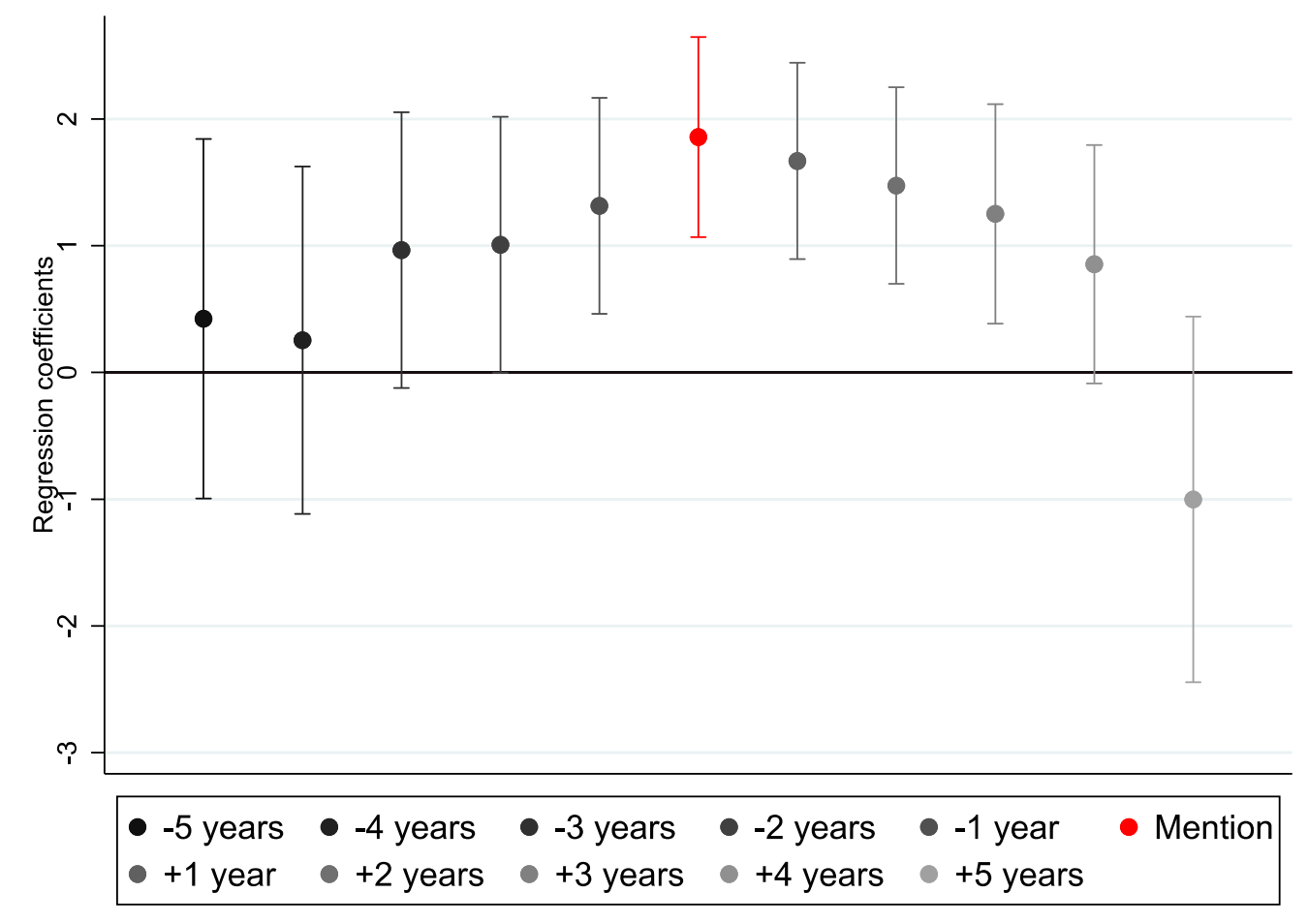

Figure C3. Placebo tests manipulating the year of consent five years backward and three years forward. Replications based on model 5 in Table 2. Markers represent regression coefficients for FIAS advisory projects completed in the last three years, and the whiskers represent $99.5 \%$ confidence intervals. 


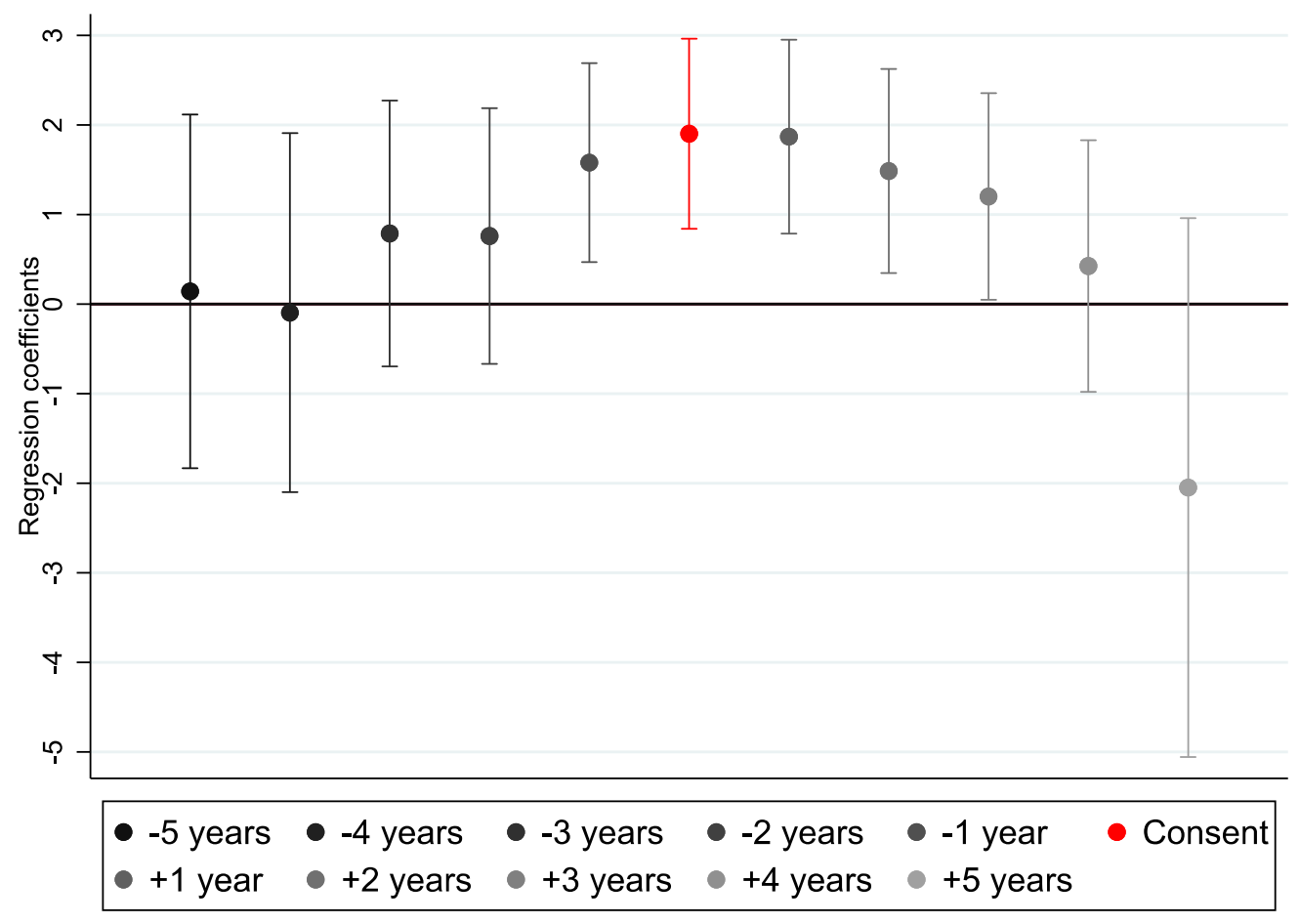

Figure C4. Placebo tests manipulating the year of consent five years backward and five years forward. Replications based on model 6 in Table 2. Markers represent regression coefficients for FIAS advisory projects completed in the last five years, and the whiskers represent $99.5 \%$ confidence intervals. 
Table C1. Pooled cross section OLS regression. Placebo tests assessing the relationship between FIAS technical assistance and domestic environmental legislation

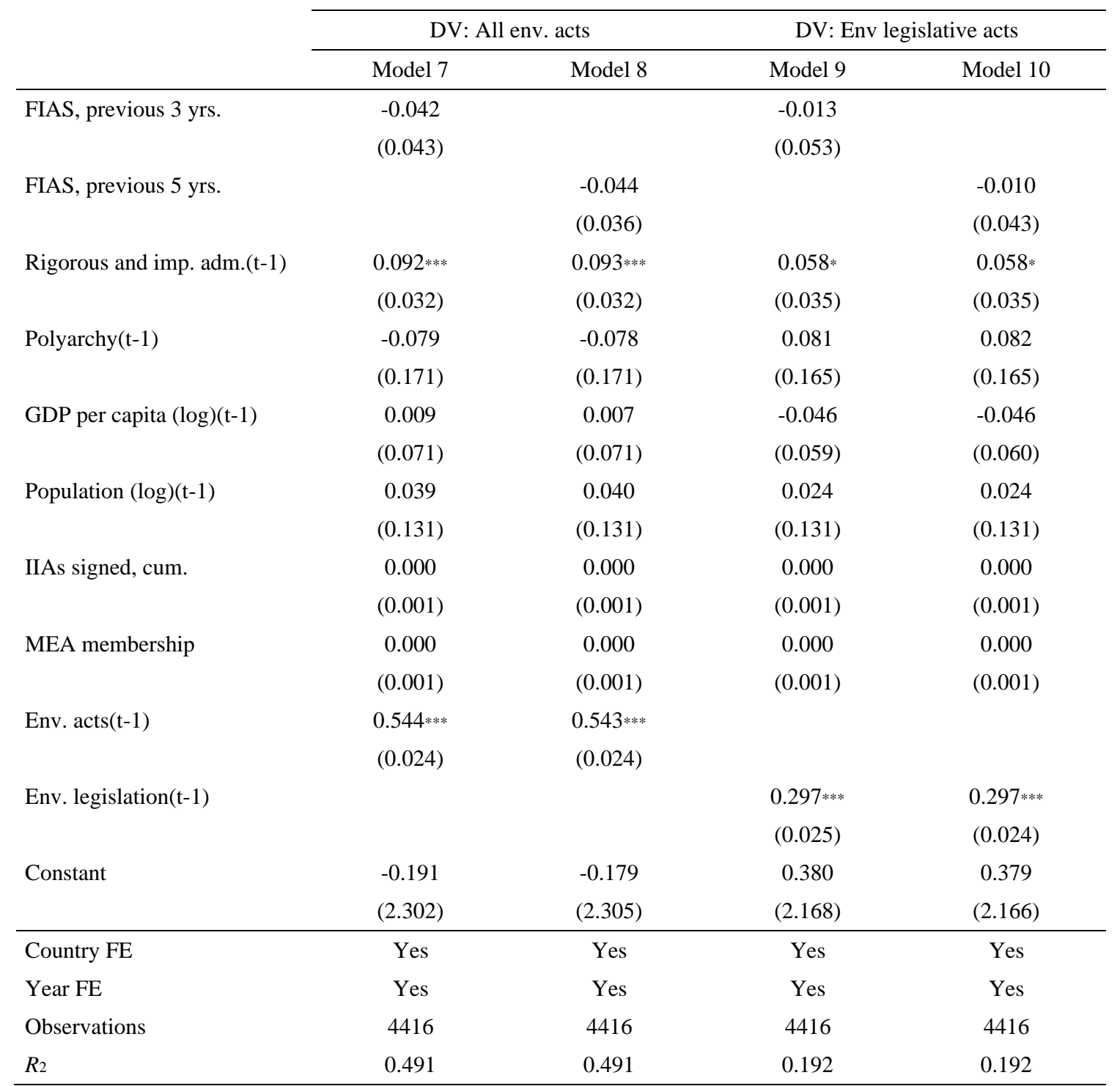

Note: All models are estimated using pooled cross section OLS regression. The dependent variable in models 7 and 8 is the natural logarithm of the sum of all environmental acts listed in ECOLEX in any given year for any given country. The dependent variable in models 9 and 10 is the natural logarithm of the sum of all environmental legislative acts. Robust standard errors clustered on countries in parentheses. $* p<0.1, * * p<0.05, * * * p<0.01$ 
Table C2. Cox regression models: FIAS and mention of arbitration in domestic investment laws, controlling for the broader advisory and donor complex

\begin{tabular}{|c|c|c|c|c|}
\hline & \multicolumn{4}{|c|}{ DV: Time-to-mention } \\
\hline & Model 15 & Model 16 & Model 17 & Model 18 \\
\hline \multirow[t]{2}{*}{ FIAS, previous 3 yrs. } & $7.549 * * *$ & $7.545^{* * *}$ & $6.110 * * *$ & $6.122 * * *$ \\
\hline & {$[4.267,13.355]$} & {$[4.256,13.377]$} & {$[3.254,11.470]$} & {$[3.250,11.530]$} \\
\hline \multirow[t]{2}{*}{ UNCTAD IPR, previous 3 yrs. } & & 1.085 & & 0.887 \\
\hline & & {$[0.217,5.423]$} & & {$[0.187,4.208]$} \\
\hline \multirow[t]{2}{*}{ Net ODA $(\log )$} & & & $1.487^{* * *}$ & $1.488^{* *}$ \\
\hline & & & {$[1.069,2.068]$} & {$[1.071,2.068]$} \\
\hline \multirow[t]{2}{*}{ Rigorous and imp. adm. } & 0.875 & 0.874 & 0.938 & 0.939 \\
\hline & {$[0.660,1.159]$} & {$[0.658,1.161]$} & {$[0.687,1.281]$} & {$[0.685,1.288]$} \\
\hline \multirow[t]{2}{*}{ Accountability } & 1.061 & 1.061 & 1.063 & 1.063 \\
\hline & {$[0.688,1.637]$} & {$[0.689,1.635]$} & {$[0.679,1.666]$} & {$[0.678,1.667]$} \\
\hline \multirow[t]{2}{*}{ GDP $(\log )$} & 1.097 & 1.096 & 0.964 & 0.965 \\
\hline & {$[0.922,1.305]$} & {$[0.919,1.306]$} & {$[0.729,1.273]$} & {$[0.730,1.275]$} \\
\hline \multirow[t]{2}{*}{ GDP per capita (log) } & $0.688 *$ & $0.689 *$ & 0.875 & 0.875 \\
\hline & {$[0.473,1.001]$} & {$[0.472,1.004]$} & {$[0.566,1.355]$} & {$[0.565,1.354]$} \\
\hline \multirow[t]{2}{*}{ Time since indep. $(\log )$} & $0.778 *$ & $0.778 *$ & $0.740 *$ & $0.740 *$ \\
\hline & {$[0.583,1.037]$} & {$[0.584,1.037]$} & {$[0.526,1.042]$} & {$[0.525,1.043]$} \\
\hline \multirow[t]{2}{*}{ Regime durability (log) } & 1.039 & 1.039 & 1.048 & 1.048 \\
\hline & {$[0.839,1.285]$} & {$[0.839,1.286]$} & {$[0.829,1.323]$} & {$[0.830,1.323]$} \\
\hline \multirow[t]{2}{*}{ Arbitration claims, cum. } & 0.864 & 0.864 & 0.905 & 0.904 \\
\hline & {$[0.703,1.061]$} & {$[0.700,1.067]$} & {$[0.747,1.095]$} & {$[0.745,1.098]$} \\
\hline \multirow[t]{2}{*}{ IIAs signed, cum. } & 0.989 & 0.989 & 0.990 & 0.990 \\
\hline & {$[0.975,1.004]$} & {$[0.975,1.004]$} & {$[0.974,1.005]$} & {$[0.974,1.005]$} \\
\hline \multirow[t]{2}{*}{ IBRD loans (log) } & 1.007 & 1.007 & 0.983 & 0.983 \\
\hline & {$[0.968,1.048]$} & {$[0.968,1.048]$} & {$[0.949,1.019]$} & {$[0.949,1.019]$} \\
\hline Spells (\# countries) & 156 & 156 & 124 & 124 \\
\hline Events (\# mentions) & 70 & 70 & 64 & 64 \\
\hline Observations & 3475 & 3475 & 2273 & 2273 \\
\hline$A I C$ & 582.661 & 584.650 & 508.181 & 510.156 \\
\hline
\end{tabular}

Note: Cox proportional hazard models, estimates in hazard ratios. 95 per cent confidence intervals in brackets. ${ }^{*} p<$ $0.1,{ }^{* *} p<0.05,{ }^{* * *} p<0.01$ 
Table C3. Cox regression models: FIAS and consent to arbitration in domestic investment laws, controlling for the broader advisory and donor complex

\begin{tabular}{|c|c|c|c|c|}
\hline & \multirow{2}{*}{\multicolumn{4}{|c|}{ DV: Time-to-consent }} \\
\hline & & & & \\
\hline & Model 19 & Model 20 & Model 21 & Model 22 \\
\hline \multirow[t]{2}{*}{ FIAS, previous 3 yrs. } & $7.549 * * *$ & $7.991 * * *$ & $6.151 * * *$ & $6.188^{* * *}$ \\
\hline & {$[4.267,13.355]$} & {$[3.786,16.868]$} & {$[2.715,13.935]$} & {$[2.687,14.248]$} \\
\hline \multirow[t]{2}{*}{ UNCTAD IPR, previous 3 yrs. } & & 0.868 & & 0.767 \\
\hline & & {$[0.098,7.681]$} & & {$[0.096,6.159]$} \\
\hline \multirow[t]{2}{*}{ Net ODA $(\log )$} & & & $1.669 *$ & $1.671 *$ \\
\hline & & & {$[0.951,2.930]$} & {$[0.957,2.919]$} \\
\hline \multirow[t]{2}{*}{ Rigorous and imp. adm. } & 0.875 & 0.921 & 0.881 & 0.887 \\
\hline & {$[0.660,1.159]$} & {$[0.601,1.413]$} & {$[0.567,1.370]$} & {$[0.566,1.391]$} \\
\hline \multirow[t]{2}{*}{ Accountability } & 1.061 & 1.196 & 0.988 & 0.988 \\
\hline & {$[0.688,1.637]$} & {$[0.655,2.183]$} & {$[0.535,1.824]$} & {$[0.537,1.818]$} \\
\hline \multirow[t]{2}{*}{ GDP $(\log )$} & 1.097 & 0.930 & 0.727 & 0.730 \\
\hline & {$[0.922,1.305]$} & {$[0.737,1.173]$} & {$[0.457,1.155]$} & {$[0.456,1.170]$} \\
\hline \multirow[t]{2}{*}{ GDP per capita (log) } & $0.688 *$ & $0.580 * *$ & 0.916 & 0.911 \\
\hline & {$[0.473,1.001]$} & {$[0.355,0.948]$} & {$[0.490,1.711]$} & {$[0.483,1.716]$} \\
\hline \multirow[t]{2}{*}{ Time since indep. $(\log )$} & $0.778^{*}$ & 0.947 & 0.934 & 0.933 \\
\hline & {$[0.583,1.037]$} & {$[0.679,1.322]$} & {$[0.650,1.341]$} & {$[0.649,1.341]$} \\
\hline \multirow[t]{2}{*}{ Regime durability (log) } & 1.039 & 1.166 & 1.158 & 1.160 \\
\hline & {$[0.839,1.285]$} & {$[0.860,1.580]$} & {$[0.828,1.620]$} & {$[0.831,1.619]$} \\
\hline \multirow[t]{2}{*}{ Arbitration claims, cum. } & 0.864 & 1.037 & 1.060 & 1.059 \\
\hline & {$[0.703,1.061]$} & {$[0.971,1.108]$} & {$[0.985,1.140]$} & {$[0.984,1.140]$} \\
\hline \multirow[t]{2}{*}{ IIAs signed, cum. } & 0.989 & $0.974 *$ & $0.971 *$ & $0.971 *$ \\
\hline & {$[0.975,1.004]$} & {$[0.947,1.002]$} & {$[0.942,1.001]$} & {$[0.942,1.001]$} \\
\hline \multirow[t]{2}{*}{ IBRD loans (log) } & 1.007 & 1.007 & 1.006 & 1.006 \\
\hline & {$[0.968,1.048]$} & {$[0.948,1.069]$} & {$[0.955,1.059]$} & {$[0.956,1.059]$} \\
\hline Spells (\# countries) & 156 & 156 & 124 & 124 \\
\hline Events (\# consents) & 35 & 35 & 33 & 33 \\
\hline Observations & 3475 & 3989 & 2727 & 2727 \\
\hline$A I C$ & 582.661 & 300.575 & 275.886 & 277.822 \\
\hline
\end{tabular}

Note: Cox proportional hazard models, estimates in hazard ratios. 95 per cent confidence intervals in brackets. $* p<$ $0.1, * * p<0.05, * * * p<0.01$ 
Table C4. Cox regression models: FIAS and mention of arbitration in domestic investment laws, controlling for investment-specific, country-level economic factors

\begin{tabular}{|c|c|c|c|c|c|c|}
\hline & Model 23 & Model 24 & Model 25 & Model 26 & Model 27 & Model 28 \\
\hline \multirow[t]{2}{*}{ FIAS, previous 3 yrs. } & $7.549^{* * *}$ & $7.202 * * *$ & $6.384 * * *$ & $7.288^{* * *}$ & $7.518^{* * * *}$ & $5.791^{* * *}$ \\
\hline & {$[4.267,13.355]$} & {$[3.948,13.139]$} & {$[3.523,11.569]$} & {$[4.120,12.895]$} & {$[4.244,13.316]$} & {$[3.108,10.789]$} \\
\hline \multirow[t]{2}{*}{ FDI inflows (log) } & & 1.121 & & & & $1.147 *$ \\
\hline & & {$[0.977,1.287]$} & & & & {$[0.976,1.348]$} \\
\hline \multirow[t]{2}{*}{ Trade (\% of GDP) } & & & 1.000 & & & 0.997 \\
\hline & & & {$[0.996,1.005]$} & & & {$[0.991,1.002]$} \\
\hline \multirow[t]{2}{*}{ IMF Credits (log) } & & & & 1.042 & & 1.041 \\
\hline & & & & {$[0.985,1.101]$} & & {$[0.973,1.114]$} \\
\hline \multirow[t]{2}{*}{ GDP growth } & & & & & $1.013^{* *}$ & 1.016 \\
\hline & & & & & {$[1.002,1.024]$} & {$[0.995,1.038]$} \\
\hline \multirow[t]{2}{*}{ Rigorous and imp. adm. } & 0.875 & 0.868 & 0.914 & 0.866 & 0.870 & 0.895 \\
\hline & {$[0.660,1.159]$} & {$[0.641,1.174]$} & {$[0.688,1.215]$} & {$[0.649,1.156]$} & {$[0.658,1.150]$} & {$[0.663,1.209]$} \\
\hline \multirow[t]{2}{*}{ Accountability } & 1.061 & 1.007 & 0.964 & 1.062 & 1.080 & 0.928 \\
\hline & {$[0.688,1.637]$} & {$[0.645,1.570]$} & {$[0.611,1.521]$} & {$[0.694,1.623]$} & {$[0.700,1.667]$} & {$[0.587,1.465]$} \\
\hline \multirow[t]{2}{*}{ GDP $(\log )$} & 1.097 & 0.985 & 1.068 & 1.069 & 1.096 & 0.887 \\
\hline & {$[0.922,1.305]$} & {$[0.795,1.220]$} & {$[0.875,1.304]$} & {$[0.893,1.279]$} & {$[0.921,1.305]$} & {$[0.679,1.159]$} \\
\hline \multirow[t]{2}{*}{ GDP per capita (log) } & $0.688^{*}$ & 0.725 & $0.644 * *$ & 0.725 & $0.691 *$ & 0.759 \\
\hline & {$[0.473,1.001]$} & {$[0.480,1.095]$} & {$[0.431,0.962]$} & {$[0.494,1.065]$} & {$[0.475,1.005]$} & {$[0.483,1.193]$} \\
\hline \multirow[t]{2}{*}{ Time since indep. $(\log )$} & $0.778 *$ & $0.768 *$ & 0.801 & 0.790 & $0.776 *$ & 0.765 \\
\hline & {$[0.583,1.037]$} & {$[0.568,1.037]$} & {$[0.571,1.123]$} & {$[0.587,1.064]$} & {$[0.581,1.035]$} & {$[0.526,1.113]$} \\
\hline \multirow[t]{2}{*}{ Regime durability (log) } & 1.039 & 1.052 & 1.015 & 1.054 & 1.029 & 1.046 \\
\hline & {$[0.839,1.285]$} & {$[0.834,1.327]$} & {$[0.808,1.275]$} & {$[0.844,1.316]$} & {$[0.831,1.276]$} & {$[0.813,1.344]$} \\
\hline \multirow[t]{2}{*}{ Arbitration claims, cum. } & 0.864 & 0.855 & 0.851 & 0.859 & 0.861 & 0.844 \\
\hline & {$[0.703,1.061]$} & {$[0.689,1.063]$} & {$[0.667,1.086]$} & {$[0.698,1.057]$} & {$[0.699,1.061]$} & {$[0.654,1.089]$} \\
\hline \multirow[t]{2}{*}{ IIAs signed, cum. } & 0.989 & $0.986 *$ & 0.989 & 0.990 & 0.989 & 0.987 \\
\hline & {$[0.975,1.004]$} & {$[0.972,1.002]$} & {$[0.974,1.004]$} & {$[0.975,1.005]$} & {$[0.975,1.004]$} & {$[0.971,1.004]$} \\
\hline \multirow[t]{2}{*}{ IBRD loans (log) } & 1.007 & 1.014 & 1.004 & 0.979 & 1.008 & 0.983 \\
\hline & {$[0.968,1.048]$} & {$[0.966,1.064]$} & {$[0.965,1.045]$} & {$[0.928,1.032]$} & {$[0.969,1.050]$} & {$[0.919,1.050]$} \\
\hline Spells (\# countries) & 156 & 154 & 155 & 156 & 156 & 153 \\
\hline Events (\# mentions) & 70 & 66 & 66 & 70 & 70 & 62 \\
\hline Observations & 3475 & 3389 & 3159 & 3475 & 3473 & 3094 \\
\hline$A I C$ & 582.661 & 546.129 & 541.355 & 582.452 & 583.522 & 506.546 \\
\hline
\end{tabular}


Table C5. Cox regression models: FIAS and consent to arbitration in domestic investment laws, controlling for investment-specific, country-level economic factors

\begin{tabular}{|c|c|c|c|c|c|c|}
\hline & \multicolumn{6}{|c|}{ DV: Time-to-consent } \\
\hline & Model 29 & Model 30 & Model 31 & Model 32 & Model 33 & Model 34 \\
\hline \multirow[t]{2}{*}{ FIAS, previous 3 yrs. } & $7.971 * * *$ & $8.184 * * *$ & $6.542 * * *$ & $7.807 * * *$ & $7.823^{* * *}$ & $6.528^{* * *}$ \\
\hline & {$[3.828,16.594]$} & {$[3.747,17.873]$} & {$[3.009,14.223]$} & {$[3.743,16.283]$} & {$[3.727,16.423]$} & {$[2.781,15.324]$} \\
\hline \multirow[t]{2}{*}{ FDI inflows (log) } & & 1.025 & & & & 1.022 \\
\hline & & {$[0.861,1.220]$} & & & & {$[0.834,1.252]$} \\
\hline \multirow[t]{2}{*}{ Trade (\% of GDP) } & & & 1.001 & & & 1.001 \\
\hline & & & {$[0.995,1.007]$} & & & {$[0.994,1.009]$} \\
\hline \multirow[t]{2}{*}{ IMF Credits (log) } & & & & 1.037 & & 1.046 \\
\hline & & & & {$[0.941,1.143]$} & & {$[0.907,1.208]$} \\
\hline \multirow[t]{2}{*}{ GDP growth } & & & & & 1.010 & 0.998 \\
\hline & & & & & {$[0.983,1.038]$} & {$[0.927,1.074]$} \\
\hline \multirow[t]{2}{*}{ Rigorous and imp. adm. } & 0.918 & 0.984 & 0.925 & 0.919 & 0.914 & 0.997 \\
\hline & {$[0.604,1.396]$} & {$[0.649,1.492]$} & {$[0.595,1.438]$} & {$[0.602,1.400]$} & {$[0.603,1.386]$} & {$[0.651,1.527]$} \\
\hline \multirow[t]{2}{*}{ Accountability } & 1.196 & 1.029 & 1.066 & 1.186 & 1.210 & 0.908 \\
\hline & {$[0.654,2.186]$} & {$[0.568,1.866]$} & {$[0.561,2.023]$} & {$[0.662,2.125]$} & {$[0.659,2.222]$} & {$[0.481,1.712]$} \\
\hline \multirow[t]{2}{*}{ GDP $(\log )$} & 0.928 & 0.874 & 0.917 & 0.906 & 0.925 & 0.835 \\
\hline & {$[0.741,1.160]$} & {$[0.659,1.158]$} & {$[0.717,1.174]$} & {$[0.712,1.154]$} & {$[0.737,1.161]$} & {$[0.585,1.190]$} \\
\hline \multirow[t]{2}{*}{ GDP per capita (log) } & $0.582 * *$ & 0.645 & $0.548 * *$ & $0.612 *$ & $0.582^{* *}$ & 0.660 \\
\hline & {$[0.359,0.945]$} & {$[0.376,1.105]$} & {$[0.326,0.922]$} & {$[0.365,1.026]$} & {$[0.358,0.944]$} & {$[0.372,1.169]$} \\
\hline \multirow[t]{2}{*}{ Time since indep. $(\log )$} & 0.947 & 0.904 & 1.017 & 0.956 & 0.950 & 0.943 \\
\hline & {$[0.679,1.322]$} & {$[0.629,1.297]$} & {$[0.676,1.529]$} & {$[0.678,1.349]$} & {$[0.680,1.329]$} & {$[0.603,1.474]$} \\
\hline \multirow[t]{2}{*}{ Regime durability (log) } & 1.165 & 1.226 & 1.119 & 1.176 & 1.161 & 1.192 \\
\hline & {$[0.858,1.582]$} & {$[0.861,1.745]$} & {$[0.798,1.570]$} & {$[0.865,1.599]$} & {$[0.851,1.583]$} & {$[0.798,1.779]$} \\
\hline \multirow[t]{2}{*}{ Arbitration claims, cum. } & 1.038 & 1.034 & 1.046 & 1.044 & 1.038 & 1.052 \\
\hline & {$[0.972,1.107]$} & {$[0.969,1.105]$} & {$[0.981,1.116]$} & {$[0.970,1.124]$} & {$[0.973,1.108]$} & {$[0.971,1.139]$} \\
\hline \multirow[t]{2}{*}{ IIAs signed, cum. } & $0.974 *$ & $0.977 *$ & $0.970 *$ & $0.975 *$ & $0.974 *$ & 0.973 \\
\hline & {$[0.947,1.002]$} & {$[0.950,1.004]$} & {$[0.939,1.001]$} & {$[0.947,1.003]$} & {$[0.947,1.002]$} & {$[0.941,1.007]$} \\
\hline \multirow[t]{2}{*}{ IBRD loans (log) } & 1.007 & 1.024 & 1.021 & 0.982 & 1.007 & 1.017 \\
\hline & {$[0.948,1.069]$} & {$[0.949,1.104]$} & {$[0.952,1.095]$} & {$[0.903,1.067]$} & {$[0.948,1.070]$} & {$[0.886,1.167]$} \\
\hline Spells (\# countries) & 156 & 155 & 155 & 156 & 156 & 154 \\
\hline Events (\# consents) & 35 & 32 & 33 & 35 & 35 & 30 \\
\hline Observations & 3989 & 3902 & 3640 & 3989 & 3987 & 3574 \\
\hline$A I C$ & 298.594 & 274.954 & 277.774 & 299.812 & 300.316 & 257.810 \\
\hline
\end{tabular}


Table C6. Exponential parametric survival models: FIAS and mention of or consent to arbitration in domestic investment laws

\begin{tabular}{|c|c|c|c|c|}
\hline & \multicolumn{2}{|c|}{ DV: Time-to-mention } & \multicolumn{2}{|c|}{ DV: Time-to-consent } \\
\hline & Model 35 & Model 36 & Model 37 & Model 38 \\
\hline \multirow[t]{2}{*}{ FIAS, previous 3 yrs. } & $8.231 * * *$ & & $8.070^{* * *}$ & \\
\hline & {$[4.866,13.923]$} & & {$[3.906,16.670]$} & \\
\hline \multirow[t]{2}{*}{ FIAS, previous 5 yrs. } & & $6.859^{* * *}$ & & $6.344 * * *$ \\
\hline & & {$[4.018,11.710]$} & & {$[2.985,13.484]$} \\
\hline \multirow[t]{2}{*}{ Rigorous and imp. adm. } & 0.869 & 0.871 & 0.923 & 0.929 \\
\hline & {$[0.657,1.150]$} & {$[0.660,1.150]$} & {$[0.627,1.359]$} & {$[0.630,1.370]$} \\
\hline \multirow[t]{2}{*}{ Accountability } & 1.119 & 1.115 & 1.194 & 1.174 \\
\hline & {$[0.724,1.730]$} & {$[0.716,1.738]$} & {$[0.671,2.123]$} & {$[0.658,2.092]$} \\
\hline \multirow[t]{2}{*}{ GDP $(\log )$} & 1.076 & 1.082 & 0.924 & 0.925 \\
\hline & {$[0.916,1.263]$} & {$[0.916,1.278]$} & {$[0.739,1.156]$} & {$[0.733,1.166]$} \\
\hline \multirow[t]{2}{*}{ GDP per capita (log) } & $0.689 *$ & $0.681 *$ & $0.555^{* *}$ & $0.546 * *$ \\
\hline & {$[0.472,1.007]$} & {$[0.460,1.007]$} & {$[0.318,0.968]$} & {$[0.304,0.979]$} \\
\hline \multirow[t]{2}{*}{ Time since indep. (log) } & $0.824 *$ & $0.811 *$ & 0.936 & 0.927 \\
\hline & {$[0.656,1.035]$} & {$[0.640,1.028]$} & {$[0.666,1.314]$} & {$[0.648,1.325]$} \\
\hline \multirow[t]{2}{*}{ Regime durability (log) } & 1.069 & 1.077 & 1.222 & 1.235 \\
\hline & {$[0.864,1.323]$} & {$[0.866,1.339]$} & {$[0.901,1.657]$} & {$[0.904,1.686]$} \\
\hline \multirow[t]{2}{*}{ Arbitration claims, cum. } & 0.915 & 0.910 & 1.026 & 1.027 \\
\hline & {$[0.794,1.055]$} & {$[0.781,1.061]$} & {$[0.950,1.109]$} & {$[0.947,1.114]$} \\
\hline \multirow[t]{2}{*}{ IIAs signed, cum. } & 0.988 & 0.988 & $0.973 *$ & $0.973 *$ \\
\hline & {$[0.974,1.002]$} & {$[0.974,1.003]$} & {$[0.945,1.002]$} & {$[0.944,1.002]$} \\
\hline \multirow[t]{2}{*}{ IBRD loans (log) } & 1.008 & 1.007 & 0.999 & 0.995 \\
\hline & {$[0.968,1.051]$} & {$[0.964,1.051]$} & {$[0.930,1.072]$} & {$[0.922,1.075]$} \\
\hline \multirow[t]{2}{*}{ Constant } & $0.000 * * *$ & $0.000 * * *$ & $0.010 *$ & $0.012 *$ \\
\hline & {$[0.000,0.005]$} & {$[0.000,0.006]$} & {$[0.000,1.124]$} & {$[0.000,1.691]$} \\
\hline Spells (\# countries) & 156 & 156 & 156 & 156 \\
\hline Events (\# mentions/consents) & 70 & 70 & 35 & 35 \\
\hline Observations & 3475 & 3475 & 3989 & 3989 \\
\hline$A I C$ & 265.682 & 270.454 & 185.493 & 189.782 \\
\hline
\end{tabular}

Note: Exponential parametric survival models. Estimates in hazard ratios. 95 per cent confidence intervals in brackets. $* p<0.1, * * p<0.05, * * * p<0.01$ 
Table C7. Logit and rare-event logit models, mention of arbitration in domestic investment laws

DV: Time-to-mention

\begin{tabular}{|c|c|c|c|c|}
\hline & \multicolumn{2}{|c|}{ Logit } & \multicolumn{2}{|c|}{ Rare event logit } \\
\hline & Model 39 & Model 40 & Model 41 & Model 42 \\
\hline \multirow[t]{2}{*}{ FIAS, last 3 yrs. } & $2.234 * * *$ & & $2.171^{* * *}$ & \\
\hline & $(0.302)$ & & $(0.276)$ & \\
\hline \multirow[t]{2}{*}{ FIAS, last 5 yrs. } & & $2.039^{* * *}$ & & $1.969^{* * *}$ \\
\hline & & $(0.298)$ & & $(0.268)$ \\
\hline \multirow[t]{2}{*}{ Rigorous and imp. adm. } & -0.115 & -0.105 & -0.138 & -0.132 \\
\hline & $(0.155)$ & $(0.153)$ & $(0.150)$ & $(0.148)$ \\
\hline \multirow[t]{2}{*}{ Accountability } & 0.004 & -0.003 & 0.090 & 0.082 \\
\hline & $(0.239)$ & $(0.242)$ & $(0.222)$ & $(0.221)$ \\
\hline \multirow[t]{2}{*}{ GDP $(\log )$} & 0.091 & 0.095 & 0.065 & 0.071 \\
\hline & $(0.092)$ & $(0.095)$ & $(0.085)$ & $(0.085)$ \\
\hline \multirow[t]{2}{*}{ GDP per capita (log) } & $-0.369 *$ & $-0.388^{* *}$ & $-0.361 * *$ & -0.377 ** \\
\hline & $(0.193)$ & $(0.198)$ & $(0.172)$ & $(0.173)$ \\
\hline \multirow[t]{2}{*}{ Time since indep. $(\log )$} & $-0.233 *$ & $-0.233 *$ & -0.194 & $-0.205 *$ \\
\hline & $(0.129)$ & $(0.132)$ & $(0.124)$ & $(0.125)$ \\
\hline \multirow[t]{2}{*}{ Regime durability (log) } & 0.043 & 0.048 & 0.058 & 0.063 \\
\hline & $(0.114)$ & $(0.115)$ & $(0.115)$ & $(0.115)$ \\
\hline \multirow[t]{2}{*}{ Arbitration claims, cum. } & $-0.199 *$ & -0.199 & 0.004 & 0.003 \\
\hline & $(0.114)$ & $(0.122)$ & $(0.068)$ & $(0.072)$ \\
\hline \multirow[t]{2}{*}{ IIAs signed, cum. } & -0.010 & -0.010 & -0.012 & -0.012 \\
\hline & $(0.007)$ & $(0.008)$ & $(0.008)$ & $(0.008)$ \\
\hline \multirow[t]{2}{*}{ IBRD loans (log) } & 0.017 & 0.014 & 0.007 & 0.005 \\
\hline & $(0.020)$ & $(0.020)$ & $(0.021)$ & $(0.021)$ \\
\hline \multirow[t]{2}{*}{ Constant } & -2.298 & -2.174 & -2.138 & -2.123 \\
\hline & $(1.972)$ & $(2.003)$ & $(1.649)$ & $(1.663)$ \\
\hline Year FE & Yes & Yes & & \\
\hline Observations & 2963 & 2963 & 3475 & 3475 \\
\hline Pseudo $R_{2}$ & 0.174 & 0.168 & & \\
\hline
\end{tabular}

Note: Logit and rare-event logit models. Robust standard errors clustered on countries in parentheses. ${ }^{*} p<0.1, * * p<$ $0.05, * * * p<0.01$ 
Table C8. Logit and rare-event logit models, consent to arbitration in domestic investment laws

\begin{tabular}{|c|c|c|c|c|}
\hline & \multicolumn{4}{|c|}{ DV: Time-to-consent } \\
\hline & \multicolumn{2}{|c|}{ Logit } & \multicolumn{2}{|c|}{ Rare event logit } \\
\hline & Model 43 & Model 44 & Model 45 & Model 46 \\
\hline FIAS, previous 3 yrs. & $2.362 * * *$ & & $2.093 * * *$ & \multirow{4}{*}{$1.844 * * *$} \\
\hline & $(0.374)$ & & $(0.364)$ & \\
\hline \multirow[t]{2}{*}{ FIAS, previous 5 yrs. } & & $2.058^{* * *}$ & & \\
\hline & & $(0.380)$ & & \\
\hline \multirow[t]{2}{*}{ Rigorous and imp. adm. } & -0.033 & -0.030 & -0.061 & -0.053 \\
\hline & $(0.217)$ & $(0.215)$ & $(0.202)$ & \multirow[b]{2}{*}{0.116} \\
\hline \multirow[t]{2}{*}{ Accountability } & 0.057 & 0.038 & 0.132 & \\
\hline & $(0.310)$ & $(0.307)$ & $(0.312)$ & \multirow[b]{2}{*}{-0.075} \\
\hline \multirow[t]{2}{*}{ GDP $(\log )$} & -0.091 & -0.090 & -0.076 & \\
\hline & $(0.121)$ & $(0.124)$ & $(0.125)$ & \multirow[b]{2}{*}{$-0.598^{* *}$} \\
\hline \multirow[t]{2}{*}{ GDP per capita (log) } & $-0.501 *$ & $-0.527 *$ & $-0.578^{* *}$ & \\
\hline & $(0.262)$ & $(0.278)$ & $(0.248)$ & \multirow[b]{2}{*}{-0.067} \\
\hline \multirow[t]{2}{*}{ Time since indep. $(\log )$} & -0.086 & -0.071 & -0.060 & \\
\hline & $(0.171)$ & $(0.177)$ & $(0.187)$ & $(0.190)$ \\
\hline \multirow[t]{2}{*}{ Regime durability (log) } & 0.128 & 0.144 & 0.184 & 0.194 \\
\hline & $(0.159)$ & $(0.160)$ & $(0.167)$ & $(0.167)$ \\
\hline \multirow[t]{2}{*}{ Arbitration claims, cum. } & 0.012 & 0.019 & $0.069 *$ & $0.071^{* *}$ \\
\hline & $(0.048)$ & $(0.047)$ & $(0.035)$ & $(0.035)$ \\
\hline \multirow[t]{2}{*}{ IIAs signed, cum. } & $-0.026 *$ & $-0.026 *$ & $-0.025 *$ & $-0.025 *$ \\
\hline & $(0.015)$ & $(0.015)$ & $(0.015)$ & $(0.015)$ \\
\hline \multirow[t]{2}{*}{ IBRD loans (log) } & 0.019 & 0.013 & -0.006 & -0.010 \\
\hline & $(0.032)$ & $(0.034)$ & $(0.030)$ & $(0.030)$ \\
\hline \multirow[t]{2}{*}{ Constant } & 2.365 & 2.416 & 1.395 & 1.578 \\
\hline & $(2.410)$ & $(2.519)$ & $(2.467)$ & $(2.487)$ \\
\hline Year FE & Yes & Yes & & \multirow[b]{2}{*}{3989} \\
\hline Observations & 2611 & 2611 & 3989 & \\
\hline Pseudo $R_{2}$ & 0.198 & 0.186 & & \\
\hline
\end{tabular}

Note: Logit and rare-event logit models. Robust standard errors clustered on countries in parentheses. ${ }^{*} p<0.1, * * p<$ $0.05, * * * p<0.01$ 


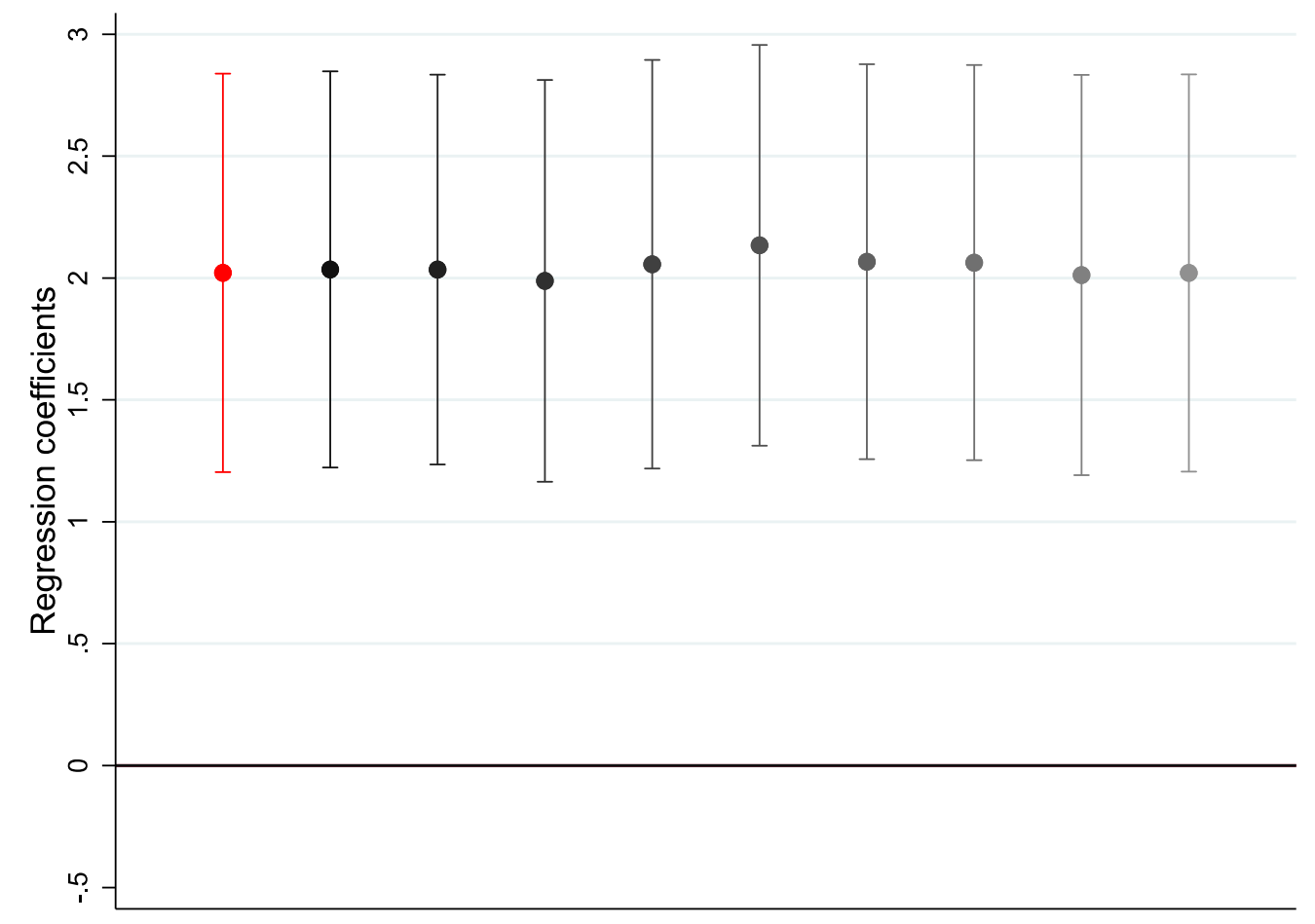

Figure C5. Sensitivity test, removing control variables one-by-one. Based on model 2 in table 2, with time-to-mention as dependent variable. Markers represent regression coefficients for FIAS advisory projects completed in the last three years, and the whiskers represent $99.5 \%$ confidence intervals. 


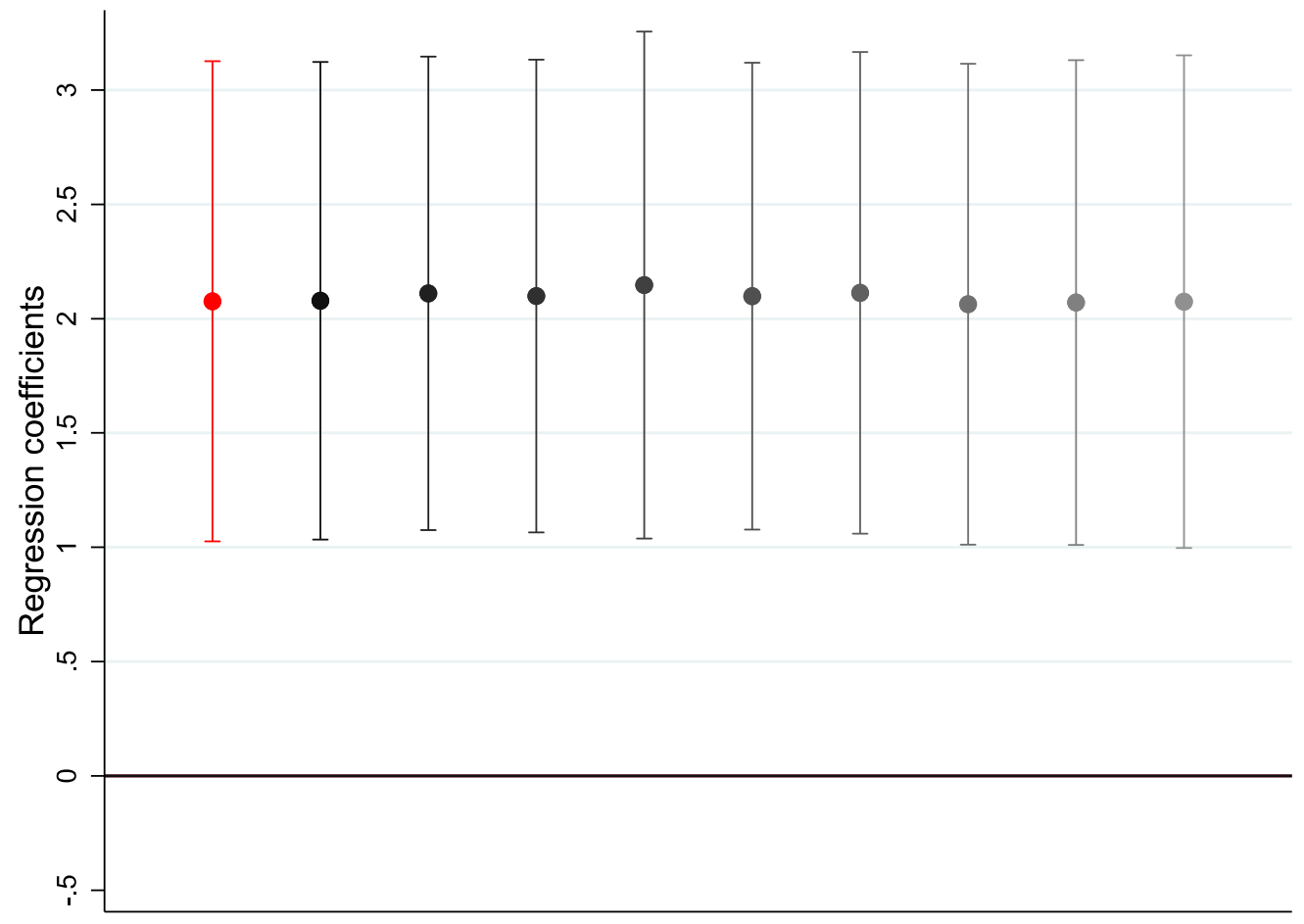

Figure C6. Sensitivity test, removing control variables one-by-one. Based on model 4 in table 2, with time-to-consent as dependent variable. Markers represent regression coefficients for FIAS advisory projects completed in the last three years, and the whiskers represent $99.5 \%$ confidence intervals. 


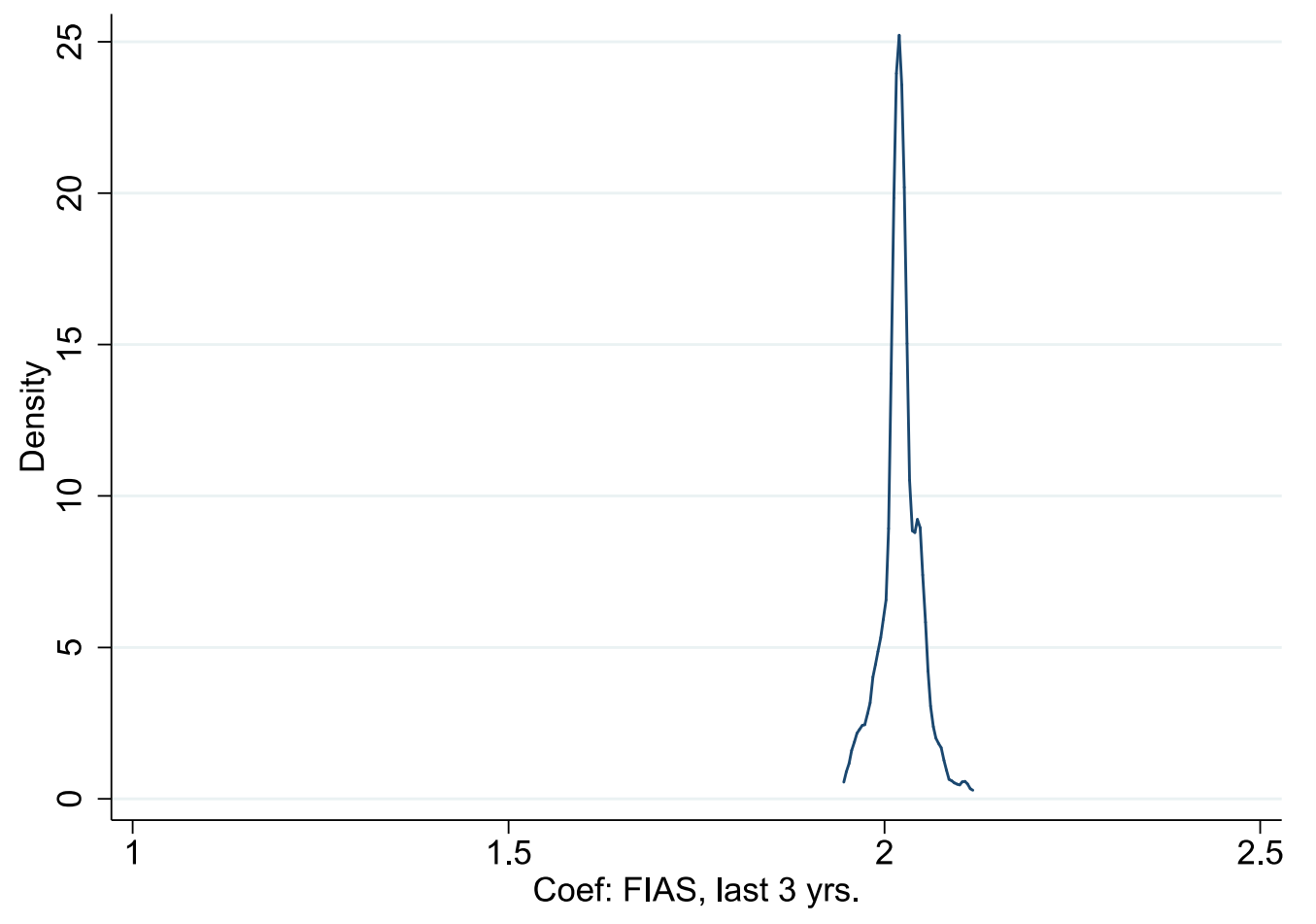

Figure C7. Sensitivity test, jackknife procedure, removing country spells one-by-one. The plot illustrates the density of the regression coefficient for 156 replications of model 2 in table 2. Time-to-consent as dependent variable. 


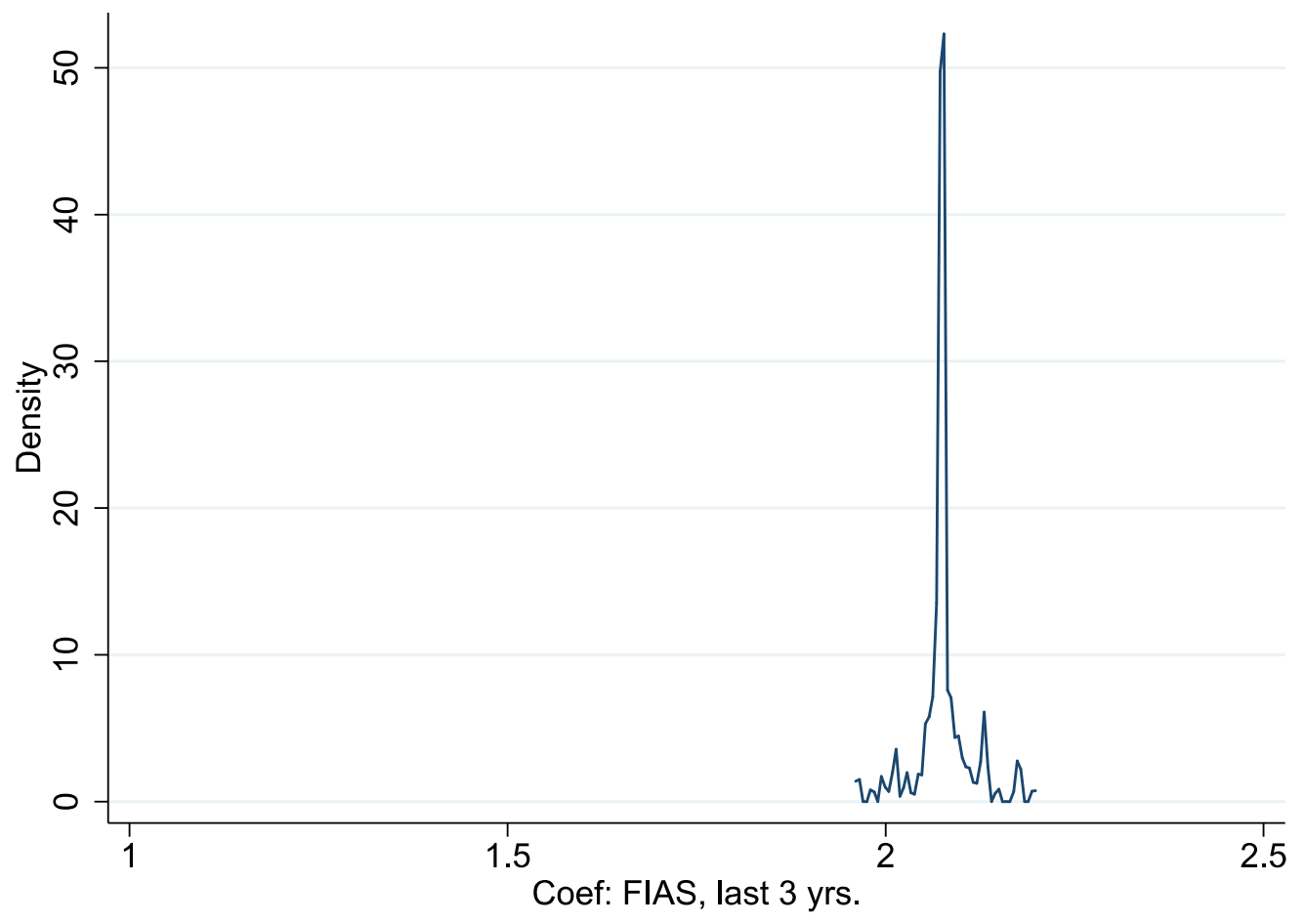

Figure C8. Sensitivity test, jackknife procedure, removing country spells one-by-one. The plot illustrates the density of the regression coefficient for 156 replications of model 2 in table 2. Time-to-consent as dependent variable. 